Cornell Law Library

Scholarship@Cornell Law: A Digital Repository

Cornell Law Faculty Publications

Faculty Scholarship

4-1989

\title{
Statutory Interpretation and the Balance of Power in the Administrative State
}

Cynthia R. Farina

CornellLaw School, crf7@cornell.edu

Follow this and additional works at: http://scholarship.law.cornell.edu/facpub

Part of the Administrative Law Commons, and the Public Law and Legal Theory Commons

\section{Recommended Citation}

Farina, Cynthia R., "Statutory Interpretation and the Balance of Power in the Administrative State" (1989). Cornell Law Faculty Publications. Paper 788.

http://scholarship.law.cornell.edu/facpub/788

This Article is brought to you for free and open access by the Faculty Scholarship at Scholarship@Cornell Law: A Digital Repository. It has been accepted for inclusion in Cornell Law Faculty Publications by an authorized administrator of Scholarship@Cornell Law: A Digital Repository. For more information, please contact jmp8@cornell.edu. 


\title{
STATUTORY INTERPRETATION AND THE BALANCE OF POWER IN THE ADMINISTRATIVE STATE
}

\author{
Cynthia R. Farina*
}

Administrative law is no longer simply about property rights. It is, instead, a system for allocating power.

$$
\text { - Judge Carl McGowan' }
$$

For those who study the interaction of courts and agencies, one of the most persistently intriguing puzzles has been to define the appropriate judicial and administrative roles in the interpretation of regulatory statutes. ${ }^{2}$ Assume, for example, that Congress enacts legislation which establishes a system of rights and responsibilities for "employees" and creates an agency to administer that system. Should the court or the agency decide whether the critical statutory term "employees" encompasses persons who would be considered independent contractors under the common law, or workers who are foremen and so, at least arguably, part of management?3 To determine "what the law is" in the context of an actual controversy that turns on a question of statutory meaning is the quintessential judicial function. ${ }^{4}$ At the same time,

* Associate Professor of Law, Cornell Law School. For their comments and contributions, I am grateful to Gregory Alexander, Alfred Aman, Paul Craig, Susan Hoffman Williams, Sheri Johnson, Ronald Levin, Russell Osgood, Richard Pierce, Peter Strauss, David Williams, and, in particular, Richard Geiger, Steven Shiffrin, and John Siliciano.

1. McGowan, A Reply to Judicialization, 1986 Duke L.J. 217, 236.

2. The debate over how courts should define and review questions of law has been joined by the prominent administrative and constitutional law scholars of every generation. See, e.g., J. Dickinson, Administrative Justice and the Supremacy of Law in the United States 49-62 (1959); J. Landis, The Administrative Process 140-53 (1938); Hart, The Power of Congress to Limit the Jurisdiction of Federal Courts: An Exercise in Dialectic, 66 Harv. L. Rev. 1362, 1377-79 (1953); 4 K. Davis, Administrative Law Treatise $\S \S 30.00-30.14$ (1958); L. Jaffe, Judicial Control of Administrative Action 546-94 (1965). Among the most interesting contemporary contributions are Diver, Statutory Interpretation in the Administrative State, 133 U. Pa. L. Rev. 549 (1985); Gerwin, The Deference Dilemma: Judicial Responses to the Great Legislative Power Giveaway, 14 Hastings Const. L.Q. 289 (1987); Levin, Identifying Questions of Law in Administrative Law, 74 Geo. L.J. I (1985) [hereinafter Levin, Identifying Questions]; and Monaghan, Marbury and the Administrative State, 83 Colum. L. Rev. 1 (1983); see also Levin, Scope of Review Doctrine Restated: An Administrative Law Section Report, 38 Admin. L. Rev. 239 (1986) [hereinafter Levin, Scope of Review].

3. The first of these questions under the National Labor Relations Act was presented in NLRB v. Hearst Publications, Inc., 322 U.S. 111 (1944), and the second in Packard Motor Car Co. v. NLRB, 330 U.S. 485 (1947).

4. See Marbury v. Madison, 5 U.S. (1 Cranch) 137, 177 (1803). We often overlook that Marbury involved questions of statutory, as well as constitutional, interpretation and that the former presented the opportunity (which the Court did not take) of deferring to the administrative interpretation of the act under which Marbury claimed his commission. See Monaghan, supra note 2, at 2. Even if, as Professor Monaghan argues, Marbury does not dictate an article III solution to the puzzle of allocating the interpretive 
however, such questions are so bound up with successful administration of the regulatory scheme that it may seem only sensible to give principal interpretive responsibility to the "expert" agency that lives with the statute constantly. And if this challenge of mediating between principle and practicality were not difficult enough, there are other pieces to the puzzle. At times, the consequence of adopting one interpretation of the statute over another is to subject an individual to civil or criminal penalties for her past behavior. Fundamental fairness to someone threatened with sanctions might require that the decisive legal standard be interpreted by a decision maker whose life tenure and salary protection promote impartiality, objectivity and insulation from political pressure. ${ }^{5}$ Finally, the legislature that enacted the statute may have had an intention about apportioning interpretive responsibility between court and agency. Determining how to "retrieve" such an intention after the fact and deciding whether, once retrieved, it is dispositive, present additional complications.

Judicial attempts, over the years, to cut through this conceptual complexity have produced a large number of statutory interpretation opinions that defy easy reconciliation. To the extent the cases can be categorized, they seem to cluster around two very different models of the proper functions of court and agency in interpreting regulatory statutes. ${ }^{6}$ In one model, the interpretive authority rests principally with the court. Using traditional techniques of statutory construction, the court exercises its own judgment to determine de novo what the statute means. ${ }^{7}$ In this "independent judgment model," the agency's function

authority between court and agency, the case epitomizes our deeply ingrained belief that providing an authoritative interpretation of legal standards is the core of the judicial function. See, e.g., Hart, supra note 2, at 1377-79. The roots of that belief run even deeper than Marbury. See, e.g., The Federalist No. 78, at 525 (A. Hamilton) (J. Cooke ed. 1961) ("The interpretation of the laws is the proper and peculiar province of the courts.").

5. The Court has flirted with this due process-based argument. See St. Joseph Stock Yards Co. v. United States, 298 U.S. 38, 84 (1936) (Brandeis, J., concurring); Crowell v. Benson, 285 U.S. 22, 45-46 (1932); see also Hart, supra note 2, at 1377-86 (distinguishing, on due process and article III grounds, court's role when agency seeks judicial assistance in coercing an individual from court's role when an individual seeks judicial help in overturning unfavorable but noncoercive administrative action). A contemporary twist to the fairness argument emphasizes the judiciary's independence from the powerful factional pressures to which agencies are susceptible. Sunstein, Factions, Self-Interest, and the APA: Four Lessons Since 1946, 72 Va. L. Rev. 271, 291-92 (I986).

6. The two models are often said to be illustrated by the Hearst and Packard cases, see, e.g., $4 \mathrm{~K}$. Davis, supra note 2, at 223-25, 229-30, although some commentators have argued that these cases, when closely analyzed, are not inconsistent. See, e.g., Monaghan, supra note 2, at 28 (reinterpreting Hearst); Levin, Identifying Questions, supra note 2 , at $24-25$.

7. The term "de novo" is not meant to suggest that the court will necessarily try the case afresh. Indeed, in many instances, the case will proceed on a record compiled before the agency. Rather, the decision is de novo in the same sense that we speak of an 
can be analogized to that of an expert witness: its view of the proper meaning becomes a factor in the court's analysis, to be given whatever persuasive effect it appears to merit in the circumstances. ${ }^{8}$ In the second model, the principal interpretive responsibility rests with the agency. The court must accept any reasonable construction offered by the agency, so long as the statutory language or, possibly, the legislative history is not patently inconsistent. ${ }^{9}$ In this "deferential model," the agency's function is to give meaning to the statute: the court determines only whether the interpretation the agency has chosen is a "rational" reading, not whether it is the "right" reading. ${ }^{10}$

appellate court reviewing, de novo, a trial court's conclusions of law: the court will reach its own independent conclusion on the record before it. See generally $1 \mathrm{~S}$. Childress \& M. Davis, Standards of Review \$ 2.14, at 76 (1986).

8. The persuasiveness of the agency's view will depend on a variety of factors, but three rough groupings can be discerned: (1) factors affecting the likelihood that the agency knows what Congress intended the statute to mean (e.g., whether the agency participated in drafting the statute; whether its position was adopted at, or shortly after, the time the statute was enacted; whether the agency's position was clearly articulated at a time when Congress re-entered the area without expressing disapproval); (2) factors affecting the likelihood that the agency knows which interpretation will best further the statutory purpose (e.g., whether the question is within the agency's area of expertise; whether the question is a fairly technical one; whether the agency has amassed experience in the area); and (3) factors going to the agency's inherent "credibility" as an expert (e.g., the thoroughness and attention with which the agency's position was formulated; whether the agency has changed its views over time; whether the agency position seems consistent and plausible, both internally and when viewed in light of its position on related issues).

9. The long-standing debate over the use of legislative history in statutory interpretation continues even among those who agree in principle with the second model. See infra note 41 .

10. In using the phrases "independent judgment model" and "deferential model," I follow the terminology of other commentators. See, e.g., Monaghan, supra note 2, at 7-14; Diver, supra note 2, at 559-67. Not everyone agrees that the cases can be viewed as establishing two distinct and very different interpretive patterns. Pointing to opinions that speak variously of according "some" deference, "considerable" deference, "great" deference and the like to the agency's interpretive position, some observers have suggested that "deference" is a complicated concept comprising varying degrees of judicial submissiveness to the agency's views on statutory meaning. See, e.g., Woodward \&: Levin, In Defense of Deference: Judicial Review of Agency Action, 31 Admin. L. Rev. 329,333 (1979). Such language about levels of deference is frequently accompanied, however, by the court's recitation of several of the factors identified supra note 8; this suggests that the word "deference," accompanied by some qualifying adjective, often serves as judicial shorthand for an assessment of the strength of the agency's "credentials" as an "expert."

As Henry Monaghan has pointed out, "[d]eference, to be meaningful, imports agency displacement of what might have been the judicial view res nova-in short, administrative displacement of judicial judgment." Monaghan, supra note 2, at 5. 1 use the term "deference" in this strong sense, to describe a style of review in which the court adopts the agency's judgment at the expense of its own. A court following the deferential model declares that the statute means what the agency says it does (so long as the agency's position is not irrational) even if the court would declare a different meaning were the interpretive question to rest in its hands alone. 
Late in its 1983 Term the Supreme Court, in Chevron U.S.A., Inc. v. Natural Resources Defense Council, Inc., ${ }^{11}$ announced the end of judicial vacillation between these two interpretive models. All six participating justices joined an opinion which endorsed deference in emphatic terms that quickly caught the attention of lower courts and commentators. ${ }^{12}$ Two years later, Young v. Community Nutrition Institute ${ }^{13}$ reiterated and strengthened Cheoron's message in an opinion in which the remaining three justices joined. ${ }^{14}$ Subsequently, the appointment of Justice Scalia added an even more determined proponent of Chevron and the deferential model. ${ }^{15}$

Coming after decades of reticulated scholarly and judicial debate about the proper allocation of interpretive authority, Chevron's justification for choosing deference was spare but powerfully direct. Justice Stevens's opinion did not attempt to assess the respective institutional competence of courts and agencies as explicators of statutory meaning. ${ }^{16}$ It avoided the article 1 III morass of identifying the "province of

11. 467 U.S. $837,842-43$ (1984).

12. Within 16 months of its issuance, Cheuron was being described as "the leading case on the subject" of statutory construction, "a case which all appellate judges these days bear firmly in mind in reading statutes." Judicial Review of Administrative Action in a Conservative Era, 39 Admin. L. Rev. 353, 356, 358 (1987) (remarks of Ronald Levin and Judge Kenneth Starr at panel discussion, Oct. 10, 1986) [hereinafter Panel Discussion]. With the passage of time, these perceptions of Chevron's importance have, if anything, increased. Justice Scalia has recently described it as "a highly important decision-perhaps the most important in the field of administrative law since Vermont Yankee." Scalia, Judicial Deference to Administrative Interpretations of Law, 1989 Duke L.J. (forthcoming); see also Pierce, Cheuron and its Aftermath: Judicial Review of Agency Interpretations of Statutory Provisions, 41 Vand. L. Rev. 301, 302 (1988) (Cheuron "has transformed dramatically the approach taken by courts in reviewing agency interpretations of statutory provisions."). The Administrative Conference of the United States has commissioned a study on deference prompted by Chevron. See Anthony, Which Agency Interpretations Should Get Judicial Deference?-A Preliminary Inquiry, 40 Admin. L. Rev. 121 (1988).

13. 476 U.S. 974, 980 (1986).

14. Justices Marshall, Rehnquist, and O'Connor had not participated in Cheuron. 467 U.S. at 839. Justice O'Connor wrote the Court's opinion in Young. 476 U.S. at 975.

15. See infra note 42 . On the Justice's general prodeference stance, at least during the period when agencies are in a deregulatory mode, see Note, Deference to Discretion: Scalia's Impact on Judicial Review of Agency Action in an Era of Deregulation, 38 Hastings L.J. 1223 (1987).

16. Chevron's choice of deference has since been praised on functional grounds. See, e.g., Pierce, supra note 12, at 303; Starr, Judicial Review in the Post-Chevron Era, 3 Yale J. on Reg. 283, 309-12 (1986). But see Breyer, Judicial Review of Questions of Law and Policy, 38 Admin. L. Rev. 363, 372-82 (1986) (Chevron's broad conception of deference is inefficient and impractical); Scalia, supra note 12 (even if agencies are more likely than courts to reach "correct" interpretive results, this is "hardly a valid theoretical justification" for deference). Colin Diver has done the most comprehensive utilitarian assessment of deference to date. See Diver, supra note 2. Although Professor Diver advocates a strong deference rule like Cheoron's, his study of the factors likely to affect the cost and quality of interpretation finds at best a modest edge for agencies and concludes frankly that "abstract comparisons of the relative competencies of courts and 
the judiciary" and the due process thicket of defining "fundamental fairness." Instead, recognizing that the choice of interpretive model is part of the larger problem of reconciling agencies and regnlatory power with the constitutional scheme, Cheoron invoked the principles of separation of powers and legitimacy. Courts must defer, the opinion explained, in order to respect the legislature's decision to entrust regulatory responsibility to agencies, ${ }^{17}$ and to ensure that the policy choices inherent in interpreting regulatory statutes are made by persons answerable to the political branches rather than by unelected judges. ${ }^{18}$

This Article pursues the constitutional path Chevron has chosen and explores the structural implications of adopting an interpretive model that allows agencies to hold principal authority for determining the meaning of the statutes under which they function. It suggests that Cheoron is a siren's song, seductive but treacherous. By portraying the choice of deference as an affirmation of legislative primacy and an enhancement of democratic control over the regulatory process, Chevron appeals to our deepest constitutional unease about allocating power in the administrative state. Ultimately, however, we cannot embrace Cheoron's vision of deference as the handmaiden to separation of powers and legitimacy principles without substantially recasting those principles-a recasting in which some aspects of existing theory would have to be abandoned and others radically reformulated. The danger of Cheoron's song lies in its apparent obliviousness to the fundamental alterations it makes in our constitutional conception of the administrative state. If we are going to embark upon such significant theoretical revision, the maguitude of the changes should be acknowledged and their consequences assessed far more candidly and carefully than the Court has done thus far.

\section{Deference According to Chevron: In Search of Clear Statements and a Constituitonal Cure-All}

When the Supreme Court in Cheuron chastised the D.C. Circuit for failing to defer to the Environmental Protection Agency's (EPA) "reasonable" reading of the Clean Air Act, it did more than merely declare the victor in a forty-year war between advocates of the deferential model and defenders of independent judgment. ${ }^{19}$ First, Chevron defined deference in a way that, while not entirely unprecedented, was far

agencies engaging in statutory interpretation yield no resounding victories for advocates of either independent or deferential review." Id. at 592.

17. Chevron, 467 U.S. at $843-44$.

18. Id. at $864-66$.

19. The 1940 s are generally credited with the emergence of deference as a serious challenger to the independent judgment approach. See, e.g., Gerwin, supra note 2, at 301-05 (tracing historical development of deference); Nathanson, Administrative Discretion in the Interpretation of Statutes, 3 Vand. L. Rev. 470 (1950) (discussing, as of 1950, whether the growing "tendency" in favor of deference should be arrested); cf. L. 
more extreme than earlier articulations of the model had been. ${ }^{20}$ Second, it justified its commitment to deference in terms resonant with revealed constitutional truth. The combination-a strong formulation of the concept of deference with an apologia invoking fundamental constitutional principles-generated a powerful new image of the appropriate functions of court and agency in the administrative state. ${ }^{21}$

Jaffe, supra note 2, at 565 ("In the 1940's judicial deference to administrative policy decisions became one of the central credos of our administrative law.").

This is not to suggest that the possibility of deference was inconceivable prior to the I940s. Cases that speak of deferring to an agency's position on the meaning of its statute can be found as early as the time of John Marshall. See Monaghan, supra note 2, at 14-15; Woodward \& Levin, supra note 10, at 332 n.11. However, determining precisely what those earlier cases meant by deference is difficult. Frequently, the courts' language-particularly when the discussion is framed in terms of factors affecting the level of deference given the agency's view-is consistent with the agency's functioning in an "expert witness" role. See supra note 8 and accompanying text.

20. Intimations of Chevron might be found in Ford Motor Credit Co. v. Milhollin, 444 U.S. 555, 565-70 (1980), and INS v. Jong Ha Wang, 450 U.S. 139, 144-45 (1981) (per curiam), cases that prompted K.C. Davis to ask "whether the Supreme Court is systematically increasing the degree of deference reviewing courts must give to administrative interpretations of statutes." $5 \mathrm{~K}$. Davis, Administrative Law Treatise, § 29.00-6, at 555 (1982 Supp.).

21. That image has provoked intense and divergent reaction in the legal community. Academics have, for the most part, approved Chevonn's strong commitment to deference, proferring both utilitarian arguments that agencies are likely to do a better job at interpretation and arguments, ultimately sounding in the Constitution, about congressional intent and the judiciary's proper role that echo those upon which the Court relied. See, e.g., R. Pierce, S. Shapiro \& P. Verkuil, Administrative Law and Process 405, 522 n.135 (1985); Diver, supra note 2; Pierce, supra note 12, at 305-08; see also Strauss, One Hundred Fifty Cases Per Year: Some Implications of the Supreme Court's Limited Resources for Judicial Review of Agency Action, 87 Colum. L. Rev. 1093, 1118-22 (1987) (by reducing courts of appeals' role in statutory interpretation, Cheoron enhances probability of uniform administration and coherent enforcement of regulatory laws). Notable exceptions include Cass Sunstein and Alfred Aman. Professor Sunstein has criticized Chevron for eviscerating judicial control over agency action in derogation of both Congress's "meta-intent" and the judiciary's constitutional responsibility to determine the legal limits of governmental action. See Panel Discussion, supra note 12, at 367-71; Sunstein, supra note 5, at 287-92. Professor Aman, emphasizing the Executive Branch-initiated deregulation that underlay the Chevron litigation, see infra notes 23-26 and accompanying text, has argued that such extreme judicial deference to presidential policy preferences is inappropriate in the context of health, safety and environmental deregulation. See Aman, Administrative Law in a Global Era: Progress, Deregulatory Change and the Rise of the Administrative Presidency, 73 Cornell L. Rev. 1101 (1988). Clark Byse, finding "merits to both the pro and con arguments relating to Cheuron" has counseled "a middle ground which will enable agencies to function effectively and, at the same time, avoid shackling reviewing courts with a single, simple indiscriminate mode of review that would materially hinder them in the performance of their essential control function." Byse, Judicial Review of Administrative Interpretation of Statutes: An Analysis of Chevron's Step Two, 2 Admin. L.J. 255, 262 (1988).

Student commentators have been more generally critical of Chevron. See, e.g., The Supreme Court, 1983 Term-Leading Cases, 98 Harv. L. Rev. 87, 252-55 (1984) (arguing that Chevron undermines safeguards against administrative arbitrariness and permits agencies to pursue political agenda of current President or agency leadership in deroga- 


\section{A. The New Shape of Deference}

Chevron began as a dispute over the meaning of the term "source" in the "new source review" program established by the 1977 amendments to the Clean Air Act. ${ }^{22}$ In its first rule making on the issue, the EPA interpreted the term to refer to each individual pollution-emitting device within a plant. ${ }^{23}$ Then the Reagan Administration came into power. Pursuant to a "Government-wide reexamination of regulatory burdens and complexities," 24 the EPA repealed the initial rule and reinterpreted "source" to mean an entire plant treated as a unit. ${ }^{25}$ This definition, the agency readily admitted, cut back the reach of the new source review program; a plant could now increase emissions from one device without triggering administrative intervention, so long as a corresponding decline in emissions from other devices avoided a net rise for the facility as a whole. ${ }^{26}$ Environmental organizations challenged the reinterpretation, and the D.C. Circuit set aside the new rule. ${ }^{27}$ That court found no clear answer to the definitional question in either the text or the legislative history of the 1977 amendments; it therefore proceeded to examine the statutory purposes. ${ }^{28}$ The agency's new read-

tion of goals and purposes of statute); Note, Coring the Seedless Grape: A Reinterpretation of Cheuron U.S.A. Inc. v. NRDC, 87 Colum. L. Rev. 986, 993-96 (1987) (favoring deference but criticizing Cheoron as overbroad).

Judges and practitioners have voiced decidedly mixed feelings, on a variety of utilitarian and normative grounds. Compare the generally negative reactions in Breyer, supra note 16, at 372-82; Mikva, How Should the Courts Treat Administrative Agencies, 36 Am. U.L. Rev. 1, 4-9 (1986); Panel Discussion, supra note 12, at 373-75 (comments of Alan B. Morrison, Director, Public Citizen Litigation Group) with the positive reactions in Starr, supra note 16; Panel Discussion, supra note 12, at 372-73 (comments of Richard Willard, Ass't Attorney General).

22. Pub. L. No. 95-95, 91 Stat. 685 (codified at 42 U.S.C. \$§ 7401-7642 (1982)).

23. 45 Fed. Reg. 52,675, 52,676 (1980) (codified at 40 C.F.R. $\$ \S 51.18$, 51 app. S, $52.24(1981))$.

24. 46 Fed. Reg. 16,280, 16,280-16,281 (1981).

25. 46 Fed. Reg. 50,766 (1981) (codified at 40 C.F.R. $\S \S 51.18,51$ app. S, 52.24 (1982)). The plant-wide definition of "source" is known as the "bubble concept." For a full account of the intricacies of the Clean Air Act, as amended, and the nature and history of the bubble concept, see Landau, Chevron, U.S.A. v. NRDC: The Supreme Court Declines to Burst EPA's Bubble Concept, 15 Envtl. L. 285 (1985).

26. See 46 Fed. Reg. 50,766 (1981). EPA's volte-face on the bubble concept typified the Reagan Administration's strategy on deregulation. Unlike his predecessor, President Reagan preferred to deregulate directly through administrative fiat, rather than to chance the uncertainties of statutory amendment through the legislative process. See Garland, Deregulation and Judicial Review, 98 Harv. L. Rev. 505, 507-08 (1985); McGowan, supra note 1, at 232.

27. Natural Resources Defense Council, Inc. v. Gorsuch, 685 F.2d 718 (D.C. Cir. 1982), rev'd sub nom. Chevron U.S.A., Inc. v. Natural Resources Defense Council, Inc., 467 U.S. 837 (1984).

28. Id. at 725-27. The use of statutory purpose as an interpretive aid has always had its critics, e.g., Easterbrook, Legal Interpretation and the Power of the Judiciary, 7 Harv. J.L. \& Pub. Pol'y 87 (1984); Radin, Statutory Interpretation, 43 Harv. L. Rev. 863 (1930); see also DeLong, New Wine for a New Bottle: Judicial Review in the Regulatory 
ing, it concluded, was inconsistent with Congress's objectives. ${ }^{29}$ In this part of its analysis, the court of appeals discussed the EPA's views on the purposes of the statute and the relationship of possible interpretations of "source" to those purposes." Quite clearly, however, the court reached its own independent conclusion on both points. ${ }^{31}$

The Supreme Court reversed, in a sharply worded opinion that accused the D.C. Circuit of "misconceiv[ing] the nature of its role."32 A court's independent task in interpreting a regulatory statute, Justice Stevens wrote, extends only so far as deciding "whether Congress has directly spoken to the precise question at issue." 33 If the court finds an "unambiguously expressed" congressional intent on the question, that intent naturally controls. ${ }^{34}$ If, however, "the statute is silent or ambiguous with respect to the specific issue," the only further judicial inquiry is whether the agency's interpretation is a rational one. ${ }^{35}$ The D.C. Circuit had erred in undertaking its own analysis of the statute's purposes and the capacity of various interpretations to serve those purposes. ${ }^{36}$ Once it had concluded that Congress did not have "a specific intention" about the meaning of "source," the court should have con-

State, 72 Va. L. Rev. 399, 405 (1986) ("The 'congressional purpose' that lawyers and judges so solemnly analyze is always a tricky beast and frequently a mythical one."), but the technique is so much a part of mainstream interpretive theory that the court of appeals's methodology could hardly be considered irregular. See generally R. Dickerson, The Interpretation and Application of Statutes 87 (1975) (for most legal writers, purpose "is the touchstone of statutory interpretation").

29. 685 F.2d at 726.

30. Id. at 727.

31. That the EPA's views played little part in shaping the court's conclusion is not surprising. In its original rule making, the Carter Administration EPA identified the purpose of the 1977 amendments as reducing harmful emissions, rather than merely preventing further deterioration in air quality; it concluded that Congress meant the new source review program to apply "to the greatest extent possible." 45 Fed. Reg. $52,675,52,697$ (1980). The pipe-by-pipe interpretation of "source," it announced, "clearly is more consistent with Congressional intent" than is the bubble. Id. In its rule making a year later, the Reagan Administration EPA perceived a different purpose behind the 1977 Amendments: allowing states "to play the primary role in pollution control." 46 Fed. Reg. 50,766, 50,767 (1981). It concluded that the bubble would give states more flexibility. Id. The revised regulations acknowledged that the amendments also aimed at enhancing (rather than maintaining) air quality, but now asserted, without explanation for the change, that the bubble was more likely to achieve this objective than was the pipe-by-pipe definition of "source." Id. at 50,768-70. Even a commentator who applauded the bubble on the merits characterized the EPA's behavior as "a fairly bald piece of politics" and found "disturbing" the prospect "that an agency could so blatantly find new statutory intent based upon changing election returns." Landau, supra note 25 , at 321 .

32. Chevron U.S.A., Inc. v. Natural Resources Defense Council, Inc., 467 U.S. 837, 845 (1984).

33. Id. at 842 .

34. Id. at $842-43$.

35. Id. at 843 .

36. Id. at 845 . 
fined itself to asking whether the EPA's current interpretation was reasonable. ${ }^{37}$

Cheuron's language so narrowly circumscribed the judicial function in statutory interpretation that it was difficult, at first, to believe Justice Stevens's opinion could be taken literally. ${ }^{38}$ Deference, Cheuron seems to say, means accepting any rational meaning the agency chooses to assign to the statute unless the court can find not only that Congress had addressed "the precise question at issue," 39 but also that it had spoken "directly," to provide a "clear," "unambiguously expressed" answer. ${ }^{40}$ Cheuron apparently permits the court to seek the enactors' intent in the legislative history as well as in the text. ${ }^{41}$ However, it excludes from the search any judicial attempt to translate imperfect legislative expression, extrapolate answers from related statutory provisions or infer congressionally preferred solutions from the statute's animating principles. ${ }^{42}$ One need not have a deconstructionist's belief in the

37. Id.

38. Indeed, early commentators often concluded their discussions of Cheuron by suggesting that the case might be a fluke. See, e.g., DeLong, The Bubble Case, $10 \mathrm{Ad}$ min. L. News 1, 6-7 (1984); The Supreme Court, 1983 Term-Leading Cases, supra note 21 , at 255 .

39. Cheuron, 467 U.S. at 842 (emphasis added). This phrase seems to have a talismanic quality; it appears three times in one short paragraph and accompanying footnotes. Id. at $842-43 \&$ n.9.

40. Id. at $842-43 \& \mathrm{c}$.9.

41. Justice Stevens's opinion treats legislative history as one of the "traditional tools of statutory construction" to be used in determining congressional intent, see id. at $843 \mathrm{n} .9,851-53$, although post-Cheuron cases have seen increasing debate over whether and to what extent it ought to be consulted. Compare 1NS v. Cardoza-Fonseca, 480 U.S. 421, 452-53 (1987) (Scalia, J., concurring in judgment) (vigorously criticizing use of legislative history) and K-Mart Corp. v. Cartier, Inc., 108 S. Ct. 1811, 1817-19 (1988) (Kennedy, J., writing in part for the court) (conducting purely textual analysis and avoiding reference to legislative history) with $K$-Marl, $108 \mathrm{~S}$. Ct. at 1822-26 (Brennan, J., concurring in part and dissenting in part) (using legislative history and even statutory purpose to discover ambiguity in what majority found unequivocal statutory text); see also Regents of The Univ. of Cal. v. Public Employment Relations Bd., 108 S. Ct. 1404, 1413 (1988) (White, J., concurring in the judgment) (insisting that, if text is unambiguous, deference must be granted unless legislative history is "quite clear" in foreclosing agency interpretation).

42. This extreme restrictiveness has provoked both sharp criticism, e.g., Sunstein, supra note 5, at 291, and high praise, e.g., Pierce, supra note 12, at 304-08. It has also been the source of some subsequent confusion-engendered largely by Justice Scalia's extreme solicitude for Cheuron.

During Justice Scalia's first term, the Court decided Cardoza-Fonseca, 480 U.S. 421, in which it refused to defer to the INS's interpretation of a portion of the Immigration and Nationality Act on grounds that the language and legislative history clearly revealed Congress's intent. Justice Scalia concurred in the judgment, but accused the Court of "eviscerati[ng]" Cheuron by "impl[ying] that courts may substitute their interpretation of a statute for that of an agency whenever, "[e]mploying traditional tools of statutory construction,' they are able to reach a conclusion as to the proper interpretation of the statute." Id. at 454 (quoting majority opinion, 480 U.S. at 446 ).

If the majority opinion had indeed approved using "traditional tools of construc- 
indeterminacy of language or a public choice theorist's conviction in the inevitability of statutory vagueness to appreciate that, if the court's independent role ends whenever ambiguity is discovered or analogy must be employed, the agency's judgment will virtually always control the interpretive outcome. ${ }^{43}$

Nevertheless, two years later, Young $v$. Community Nutrition Institute 44 confirmed the Court's willingness to apply Cheoron literally. At issue was the scope of the Secretary of Health and Human Service's obligation, under the Federal Food, Drug, and Cosmetics Act ${ }^{45}$ to regnlate the addition of "poisonous or deleterious" substances to food. The statute provided that "the Secretary shall promulgate regulations limiting the quantity [of poisonous or deleterious substances] therein or thereon to such extent as he finds necessary for the protection of public health." 46 The question was whether the italicized phrase modifies the verb "shall promulgate" or the phrase "limiting the quantity." The former reading, advocated by the agency, would give the Secretary dis-

tion" to determine what the statute means, the case would have been a major retreat from Cheuron, for the search for "meaning" has traditionally extended beyond the question of specific congressional intent to a broader inquiry into statutory purpose. See supra note 28. However, that is not what happened. The Department of Justice had argued that Chevron required the Court to afford the INS's construction "substantial deference, even if we conclude that the Court of Appeals' reading of the statutes is more in keeping with Congress' intent." Id. at 445 (footnote omitted) (emphasis added). That argument, of course, patently misread Chevron. In response, Justice Stevens quoted Chevron extensively and then wrote: "The question whether Congress intended the two standards to be identical is a pure question of statutory construction for the courts to decide. Employing traditional tools of statutory construction, we have concluded that Congress did not intend the two standards to be identical." Id. at 446 (footnote omitted). The majority's reference to using "traditional tools of statutory construction" thus came in the thoroughly Chevron-like context of ascertaining Congress's specific intent with regard to particular statutory language, not-as Justice Scalia suggested-in the context of a broader search for meaning. Nevertheless, his dire predictions of Chevron's demise caused some lower courts to interpret Cardoza-Fonseca as limiting deference to cases that do not involve a "pure question of statutory construction." See, e.g., Union of Concerned Scientists v. Nuclear Regulatory Comm'n, 824 F.2d 108, 113 (D.C. Cir. 1987). That interpretation-which would directly overrule Cheuron itself and which, in the end, stems more from the consteruation in Justice Scalia's concurrence than from anything in the majority opinion-finds no support in any of the Court's post-CardozaFonseca opinions, a fact Justice Scalia has himself recently emphasized. See NLRB v. United Food \& Commercial Workers Union Local 23, 108 S. Ct. 413, 426 (1987) (Scalia, J., concurring).

43. On deconstructionism, see generally J. Derrida, English Writing and Difference (1978).

Public choice analysis posits that "statutes are deliberately rendered vague to enable politicians to support particular legislation that pleases certain constituencies without alienating others." Barnett, Foreword: Judicial Conservatism v. A Principled Judicial Activism, 10 Harv. J.L. \& Pub. Pol'y 273, 288 (1987).

44. 476 U.S. 974 (1986).

45. Pub. L. No. 75-717, 52 Stat. 1040 (1938) (current version at 21 U.S.C. $\S \S 301-392$ (1982 \& Supp. IV 1986)).

46. 21 U.S.C. $\S 346$ (1982) (emphasis added). 
cretion not to promulgate any limiting regulation for a concededly harmful substance. The latter reading, adopted by the D.C. Circuit, ${ }^{47}$ would give discretion only in the extent of the limitation imposed. Again the Court, this time through Justice O'Connor, reversed the court of appeals. Her opinion painstakingly reviewed Chevron in the manner of a teacher coaching a slow learner. Congress, she agreed, had indeed attempted to speak "directly to the precise question at issue."48. However, she emphasized, it had not "unambiguously expressed its intent through its choice of statutory language."49 Because of the unhappily placed modifier, the statute's phrasing permitted either interpretation. ${ }^{50}$ The agency's construction should therefore have been accepted, for it was "sufficiently rational to preclude a court from substituting its judgment." 51

Young graphically demonstrates the extremism of which the new deference is capable. In the world according to Chevron, the judiciary's role in interpreting regulatory statutes amounts to little more than serving as a mouthpiece for legislative directives that are unequivocal

47. Community Nutrition Inst. v. Young, 757 F.2d 354, 359-60 (D.C. Cir. 1985), rev'd, 476 U.S. 974 (1986).

48. Young, 476 U.S. at 980 .

49. Id.

50. Id. at 980-81. The Court did not find illuminating legislative history which indicated that Congress had revised the language of the section from "the Secretary is authorized to promulgate regulations" to "the Secretary shall promulgate regulations." Id. at 983.

51. Id. at 981.

Ironically, the only dissenter was Justice Stevens. Arguing that "[ $t] 0$ one versed in the English language, the meaning of this provision is readily apparent," he lectured the majority that "[ $t]$ he task of interpreting a statute requires more than merely inventing an ambiguity and invoking administrative deference." Id. at 984, 988 (Stevens, J., dissenting). Coming from the author of Cheoron, such language is surprising and might induce speculation that Justice Stevens has begun to feel uncomfortably like Dr. Frankenstein.

Rather than betraying second thoughts about Chevron, however, Justice Stevens's Young dissent apparently illustrates only that even judges committed to a strong version of deference will disagree, in specific cases, about the point at which ambiguity is encountered. Thus, in the immediately post-Cheuron case of Chemical Mfrs. Ass'n v. Natural Resources Defense Council, Inc., 470 U.S. 116 (1985), Justice O'Connor, who would author Young, joined with Justices Marshall, Stevens and Blackmun to dissent from the majority's finding of ambiguity. Id. at 152 (Marshall, J., dissenting). In the post-Young case of INS v. Cardoza-Fonesca, 480 U.S. 421 (1987), Justice Stevens, writing for a majority that included Justice O'Connor, found unambiguous intent in the statutory text and legislative history, id. at 432-33, while Justices Powell, Rehnquist and White found the same materials ambiguous, id. at 459-61 (Powell, J., dissenting), and Justice Scalia found the text alone unambiguous, id. at 452 (Scalia, J., concurring). Most recently, the Court splintered badly on whether the Tariff Act of 1930 was unclear on the issue of "gray market" goods. See K Mart Corp. v. Cartier, Inc., 108 S. Ct. 1811 (1988). In part, the division reflected disagreement about the appropriateness of using legislative history, see supra note 41 , but even justices looking at the same materials reached opposite conclusions on ambiguity. For example, compare id. at 1817-19 (Kennedy \& White finding text ambiguous) with id. at 1831-36 (Scalia, Rehnquist, Blackmun \& O'Connor finding text unambiguous). 
and directly on point. 52 Whenever such a communication cannot be conveyed, the court must step aside to free the agency (within the modest constraints of making a rational choice) to resolve what its statute shall mean, even when "the resolution involves defining the limits of the agency's authority." 53

52. One commentator has observed that a conception of the judicial function as limited to an almost ministerial enforcement of the "positive commands of a statute's literal words" has been a deliberate and pervasive legacy of the Burger Court. See Note, Intent, Clear Statements, and the Common Law: Statutory Interpretation in the Supreme Court, 95 Harv. L. Rev. 892, 898 (footnote omitted), 894-95 (1982). Written before Chevron was decided, this Note suggests that the Court's increasingly mechanistic approach to interpretation can be attributed to "a vague judicial hostility to regulatory legislation," id. at 911 , a hostility that leads the Court to refuse to use interpretation as an occasion for enhancing the ability of statutes to effectuate the animating legislative purpose or for mitigating their occasional harsh or inequitable results. Since the consequence of deference thus far has been to facilitate administratively orchestrated deregulation, Chevron is superficially consistent with the thesis of judicial hostility to the contemporary regulatory enterprise. However, when the judiciary's role is confined to enforcing the legislature's "clear statements," the necessary consequence is to enlarge the agency's power and, as Alan Morrison has warned the enthusiasts of Cheoron, agencies under a Democratic administration may employ this power for very different objectives. See Panel Discussion, supra note 12, at 375-76.

53. Mississippi Power \& Light Co. v. Mississippi ex rel. Moore, 108 S. Ct. 2428, 2444 (1988) (Scalia, J., concurring in the judgment).

Justice Brennan has recently argued that Cheoron does not apply if "the statute is designed to confine the scope of the agency's jurisdiction to the areas Congress intended it to apply," id. at 2446 (Brennan, J., dissenting)-an assertion that provoked Justice Scalia vehemently to insist: "[I]t is settled law that the rule of deference applies even to an agency's interpretation of its own statutory authority or jurisdiction." Id. at 2443 (Scalia, J., concurring in the judgment). Even allowing for his partisanship where Chevron is concerned, Justice Scalia's characterization of the case law since Chevron is accurate. In Young, the Court did not even pause over the fact that, by allowing the FDA to choose between the mandatory and permissive readings of the statute, the result was to permit the agency to decide whether or not it was under a legal duty to act. More striking, in Japan Whaling Ass'n v. American Cetacean Soc'y, 478 U.S. 221 (1986), the Court deferred to the Secretary of Commerce's view that a recent amendment to the Maguuson Fishery Conservation and Management Act did not require him to take a certain action that would culminate in sanctions against Japan for its whaling activity; deference was accorded even though, as the Court readily acknowledged, the Act had been amended for the express purpose of correcting what Congress perceived to be the Executive's repeated failure to invoke available antiwhaling sanctions. See id. at 226, 233. In Commodity Futures Trading Comm'n v Schor, 478 U.S. 833 (1986), the Court found clear congressional intent to give the agency jurisdiction to adjudicate a certain class of claims, but then deliberately went on to chide the court of appeals for thinking that the " "statutory interpretation/jurisdictional" " nature of the issue made deference to the agency's (pro-jurisdiction) view inappropriate. See id. at 845.

In sum, neither the langnage of Chevron nor the Court's post-Chevron practice supports Justice Brennan's suggestion that deference does not apply if the issue concerus the scope of the agency's powers or duties. Nevertheless, his dissent was joined by Justices Marshall and Blackmun and may signal the beginning of the Court's first siguificant conceptual rift over Chevron. For a helpful pre-Cheoron discussion of the usefulness of "jurisdiction" as a determinant of the appropriate level of deference, see Levin, Re- 


\section{B. The Appeal of Deference}

By its very extremism, the Cheuron/Young articulation of deference underscores a critical point: the choice of interpretive model is ultimately a choice about allocating power, the power that results from ambiguity. When Congress has failed to speak clearly or comprehensively, who gets to decide what the law is? If a nonregulatory statute ${ }^{54}$ is obscure or silent on a dispositive issue, the court proceeds to construct legal meaning out of whatever the enactors did supply. Although we continually debate how this process of meaning elaboration ought to occur, ${ }^{55}$ we rarely question the appropriateness of the judiciary's undertaking it-perhaps because no other option readily exists. ${ }^{56}$ When a regulatory statute is ambiguous, however, the agency stands as a potential alternative recipient of the power inevitably created by the legislature's finite capacity for prescience and precision in expression. The rigid, literalistic approach Chevron and Young adopt towards whether Congress has expressed a judicially cognizable "intent" simply increases the quantum of power at stake in the selection of interpretive model.

Once these considerable power-shifting implications are recognized, the choice between independent judgment and deference be-

view of "Jurisdictional" Issues Under the Bumpers Amendment, 1983 Duke L.J. 355, 371-78.

54. Here I am using "regulatory" in the very specific sense of a program of governmental control intended to be implemented on an ongoing basis by an administrative agency. This narrow usage is not meant to deny that legislatures often use courts to "regulate" in a broader sense, by entrusting sweeping statutory entitlements or prohibitions to judicial enforcement. See infra note 77 and accompanying text. My purpose here is simply to distinguish between statutes in which the judiciary has a natural monopoly on interpretation and statutes in which another governmental entity could make a competing claim.

55. This debate involves not only the techniques but also the nature and goals of the interpretive enterprise. See, e.g., Macey, Promoting Public-Regarding Legislation Through Statutory Interpretation: An Interest Group Model, 86 Colum. L. Rev. 223, 226-27 (1986); infra note 61 .

56. In this situation, judicial provision of statutory meaning appears as a natural, if not inescapable, component of adjudicating. See, e.g., Ginsburg, A Plea for Legislative Review, 60 S. Cal. L. Rev. 995, 1001 (1987) ("[Judges] do not iguite the conflagrations that produce litigation but, if their authority is properly invoked, they 'must respond to all calls.' ") (quoting Judge Irving L. Goldberg); see also Monaghan, supra note 2, at 13 (describing the paradigm of common-law court adjudication: "Meaning . . . is to be supplied entirely by the courts; and in the courthouse there is no room for a 'reasonable' but 'wrong' interpretation, or for a 'no right answer' approach."). There are, of course, frequent complaints that courts are too often forced to give meaning to imprecise, incomplete or inconsistent statutes-complaints voiced most loudly by federal judges. E.g., Edwards, The Role of a Judge in Modern Society: Some Reflections on Current Practice in Federal Appellate Adjudication, 32 Clev. St. L. Rev. 385, 424-25 (1983-84); Friendly, The Gap in Lawmaking-Judges Who Can't and Legislators Who Won't, 63 Colum. L. Rev. 787, 793-96 (1963); Ginsburg, supra, at 997-1001. But surely Judge Easterbrook voices an uncommon, if not idiosyncratic, view when he argues that judges faced with unclear statutes should respond by being "more willing' to put statutes back down, read but unconstrued." Easterbrook, supra note 28, at 99. 
comes part of the vexing larger problem of managing the power generated by regulatory statutes. Over the course of this century, congressional decisions to intervene in almost every significant aspect of the economic and social order have brought an enormous increase in the magnitude and pervasiveness of extant federal authority. ${ }^{57}$ The statutes that accomplish this intervention establish ambitious goals for resolving complex and far-reaching problems. Rarely do they set out a clear program for attaining their objectives. ${ }^{58}$ That a careful reading often reveals those objectives to be unattainable or even antagonistic, that reflection often leads to the suspicion that the problems addressed are intractable, only heightens our perception that a vast reservoir of governmental power has been created with relatively little provision for channeling its use. We are therefore obsessed with the question of allocating that power, anchoring it within the scheme of representative democracy, rendering it safe as well as effective. ${ }^{59}$

57. From the five that existed at the beginning of this century, the number of federal regulatory agencies has grown to over 80 . R. Litan \& W. Nordhaus, Reforming Federal Regulation 46 (1983). The New Deal marked the first major stage of this expansion, see S. Breyer \& R. Stewart, Administrative Law and Regulatory Policy 29-30 (2d ed. 1985), although the seeds of a radically different attitude about the federal government's role in the nation's social and economic affairs can be found in the post-Civil War passage of legislation providing federal protection for civil rights and creating the earliest of the modern regulatory agencies, the Interstate Commerce Commission. See Smith, Judicialization: The Twilight of Administrative Law, 1985 Duke L.J. 427, 433 \& n.13. The 1960 s and 1970 s saw a second burst of regulatory growth, oriented principally towards protection of the environment and enhancement of social welfare. See $S$. Breyer, Regulation and Its Reform I (1982). In the decade between 1965 and 1975 alone, 26 new federal agencies were created to deal with such issues. Note, supra note 15, at 1228. By 1977 the Federal Register, which provides a rough measure of the extent of regulatory activity and which at the height of the New Deal had numbered about 3000 pages annually, had grown to more than 65,000 pages. S. Breyer, supra, at 1 .

58. The explanation usually offered for this phenomenon is that the political consensus required to pass legislation will likely extend no farther than the need to regulate and an articulation of general goals; because the specific means by which those goals will be implemented tend to have far more immediate impact on interest groups, successful compromise on means is difficult to achieve. See, e.g., Pierce \& Shapiro, Political and Judicial Review of Agency Action, 59 Tex. L. Rev. 1175, 1197 (1981).

59. The literature of that obsession is enormous. Such classics as J. Freedman, Crisis and Legitimacy in the Administrative Process, 27 Stan. L. Rev. 1041 (1975) and R. Stewart, The Reformation of American Administrative Law, 88 Harv. L. Rev, 1667 (1975), have been augmented by numerous and widely varied analyses of the problems posed by regulatory power and even more divergent proposals for solving those problems. E.g., Bruff, Legislative Formality, Administrative Rationality, 63 Tex. L. Rev. 207 (1984); Cutler \& Johnson, Regulation and the Political Process, 84 Yale L.J. 1395 (1975); McGowan, Congress, Court, and Control of Delegated Power, 77 Colum. L. Rev. 1119 (1977); Pierce \& Shapiro, supra note 58; Strauss, The Place of Agencies in Government: Separation of Powers and the Fourth Branch, 84 Colum. L. Rev. 573 (1984); Sunstein, Constitutionalism After the New Deal, 101 Harv. L. Rev. 421 (1987). For a helpful overview and ambitious attempt to synthesize much of the literature, see Sargentich, The Reform of the American Administrative Process: The Contemporary Debate, 1984 Wis. L. Rev. 385. 
This anxiety-about the fate of regulatory authority impels Chevron's choice of the deferential model. Power exercised by someone other than its designated possessor is power abused. Deference is necessary, Chevron argues, to avoid judicial usurpation of functions Congress wished to entrust to the agency. ${ }^{60}$ If the judiciary displaces the conclusions of the legislature's chosen administrative delegate with its independent views on statutory meaning, it frustrates the will of a coordinate branch for its own aggrandizement. From this same concern for power seeping into the wrong institutional hands, Cheuron derives an additional justification for deference. The process of statutory interpretation inevitably involves some lawmaking, as well as law finding, component. ${ }^{61}$ Because the judiciary is the branch least accountable to the people, Cheoron reasons, the court is not a suitable organ for exercising policy-making power. Agencies, of course, are not elected entities either. But, Cheuron asserts, they are answerable to the political branches. If the judiciary substitutes its judgment on questions of statutory meaning for the views of the agency, even this secondary link to the electorate will be lost. ${ }^{62}$

Both of these justifications for deference are rooted in the central constitutional principle of separation of powers. The first (hereinafter referred to as the "judicial usurpation" argument) condemns the independent judgment model as judicial interference with the legislature's prerogative to advance the public good in the way it deems fitthat is, by giving interpretive leeway to expert agencies. The second (hereinafter the "interference with legitimate political control" argu-

60. See Cheoron, 467 U.S. at 843-44. Cheuron's equation of statutory ambiguity or silence with congressional intent that the agency decide the matter is discussed infra notes 65-97 and accompanying text.

61. The conception of interpretation as an amalgam of finding law and making law has been challenged during the extraordinarily rich contemporary debate about the nature and goals of the interpretive process. Scholars as diverse as Ronald Dworkin and Frank Easterbrook have insisted that the dichotomy is a false, or at least a useless, one. See R. Dworkin, Law's Empire 313-54 (1986); Easterbrook, supra note 28, at 97. Still, the view that interpretation combines law-finding and lawmaking functions is widely shared. See, e.g., Dickerson, Statutory Interpretation: Dipping into Legislative History, 11 Hofstra L. Rev. 1125, 1127-28 (1983); Diver, supra note 2, at 559, 573.

Of course, even accepting the general proposition that interpretation combines lawmaking and law finding, the proportions of the mixture will vary, not only from statute to statute and issue to issue but also according to how one defines the two constituent elements. If, for example, one conceives of the law-finding component as including creative reconstruction of the enactors' wishes through techniques of analogy and deriving preferences about means from statements about ends, then law finding will appear to be a far more prominent part of the interpretive process than if one accepts the Chevron/Young view, which limits law finding to locating an unambiguously expressed and precisely focused directive in the statutory text and legislative history. For widely divergent views on the extent to which interpretation is law finding, see Easterbrook, supra note 28; Epstein, The Pitfalls of Interpretation, 7 Harv. J.L. \& Pub. Pol'y 101 (1984); Pierce, supra note 12, at 305-08; Sunstein, supra note 5, at 284-91.

62. Chevron, 467 U.S. at 865-66, quoted infra text accompanying notes 210 \& 251. 
ment) emphasizes the importance of each branch exercising the governmental function for which it is peculiarly suited. The judiciary, it asserts, is an inappropriate body to make the kinds of policy choices that are unavoidable in construing contemporary regulatory statutes. In addition to reflecting separation of powers considerations, this second justification for deference voices fundamental concerns about legitimacy. It echoes the Lockean view that the exercise of power in a democratic government can be defended only through accountability to its source, the electorate. ${ }^{63}$

Because they respond directly to our collective unease about the growth of regulatory authority, Cheoron's two justifications for choosing the deferential model are deeply appealing. If deference is indeed the ally of separation of powers and legitimacy, then the rejection of independent judgment represents the triumph of fundamental constitutional values in an area riddled with constitutional doubts. ${ }^{64}$

In the end, however, Cherron's solution to the puzzle of allocating the interpretive power is only as sound as its premises. The balance of this Article scrutinizes those premises. It suggests that the "judicial usurpation" and "interference with legitimate political control" arguments rest on factual assumptions that are, at best, dubious and on theoretical assumptions that work extraordinary, yet unacknowledged, alterations in the constitutional ground rules.

\section{INDEPENDENT JUdGMENT AS Judicral USURPATION?}

Cherron's conclusion that deference is necessary to prevent the judiciary from arrogating power Congress wished to place in administrative hands requires acceptance of two propositions: First, Congress intends, as a factual matter, that agencies take principal responsibility for determining what regulatory statutes mean; and second, Congress is unconstrained, as a matter of constitutional doctrine, in choosing to entrust such responsibility to agencies. While both these propositions are critical to the "judicial usurpation" justification for deference, neither is self-evident-and neither is critically examined by the Chevron Court. In fact, the first proves to be extremely problematic, while the

63. John Locke's influence on the legitimacy ideal is discussed infra notes 254-56 and accompanying text.

64. Moreover, when thus grounded in normative considerations, the commitment to deference becomes invested with an authoritativeness, a reassuring certitude, that could never be achieved were the choice of interpretive model to be based on a debatable pragmatic assessment of the respective interpretive competence of agencies and courts. See supra note 16. This seems to be important to the Court, for the act of choosing an interpretive model not only determines who will hold the power created by the ambiguity of regulatory statutes but also is itself an exercise of power that must be justified. Cf. Note, supra note 52, at 902-03 ("[T] he clear-statement model acknowledges that allocation of the power to resolve particular questions of statutory meaning is itself an exercise of discretion."). 
second can be accepted only by repudiating fundamental aspects of existing theory.

\section{A. Chasing the Will-o'-the-Wisp of "Interpretive Intent"}

If Congress, when it enacts regulatory legislation, intends that the implementing agency will resolve a particular question of statutory meaning, then a court would indeed be contravening the legislative will to treat the issue as a matter for independent judicial determination. On these facts, the validity of the "judicial usurpation" justification for deference would turn solely on whether any constitutional principle prevents effectuation of the legislature's "interpretive intent." 65 However, this set of facts-in which Congress both perceives the need for future interpretation and formulates an intent that it be accomplished by the agency-is only one of four logically possible scenarios.

Alternatively, Congress may recognize that its words will require interpretation and assume that the court will resolve questions of statutory meaning in the normal course of appropriate litigation. In this scenario, the legislature has an interpretive intent, but its principal object is the judiciary, not the agency. ${ }^{66} \mathrm{~A}$ third possibility is that Congress means to provide the substantive answer itself, but instead unwittingly creates an interpretive question by failing to express its answer clearly. In such a case, the legislature's intention-unsuccessfully implemented-is not to delegate to any other entity the power to determine meaning. ${ }^{67}$ Finally, Congress may have no intent whatsoever

65. This phrase refers to Congress's intent not as to what the statute means, but as to the process by which that meaning is to be ascertained.

Any attempt to employ "legislative intent" as a decisional criterion encounters subtle and difficult problems that have generated a wealtb of scholarly attention. See, e.g., R. Dworkin, supra note 61, at 315-27; R. Posner, The Federal Courts: Crisis and Reform, 267-70 (1985); Easterbrook, The Supreme Court, 1983 Term-Foreword: The Court and the Economic System, 98 Harv. L. Rev. 4, 14-18 (1984); Macey, supra note 55 , at 238-40; Radin, supra note 28 , at $869-71$. Fortunately, it is unnecessary for present purposes to attempt to resolve them. The judicial usurpation argument assumes that "legislative intent" exists and can be ascertained. The argument can be critiqued by accepting these assumptions at face value, especially since Congress's interpretive intent, even if it could reliably be determined, is not constitutionally dispositive. See infra notes $98-208$ and accompanying text.

66. Cf. Brennan, Some Thoughts on the Supreme Court's Workload, 66 Judicature 230,233 (1983) (suggesting that "compromise ... often accounts for the studied ambiguity of legislative language, deliberately adopted to let the courts put a gloss on the words that the legislators could not agree upon").

67. Young appears to illustrate this scenario. The clause "the Secretary shall promulgate regulations limiting the quantity [of harmful or deleterious substances] to such extent as he finds necessary for the protection of the public health," see supra note 46 and accompanying text, was doubtless intended to mean one of the two readings proposed by the litigants, but that intention was muddled by an unfortunate sentence structure.

Note that Cheuron's clear statement approach, with its insistence that substantive intent be conveyed unambiguously and precisely, has little tolerance for the vagaries of 
about interpretive responsibility or its allocation. This could occur because the substantive question is unknowable or, if theoretically knowable, is unrecognized at the time the legislature acts, ${ }^{68}$ or because the question is lost or deliberately bypassed in the process of hammering out the regnlatory package. ${ }^{69}$

Whenever one of these latter three scenarios accurately describes the state of Congress's "intent" on a given issue of statutory meaning, it is simply inaccurate to suggest that the independent judgment approach would constitute judicial usurpation of power legislatively designated for another. Of course, discerning, for each statutory provision requiring interpretation, which scenario correctly describes the enactors' intent is likely to be a formidable, if not an impossible, task. ${ }^{70}$ Chevron sidesteps this difficulty by announcing a presumption. If Congress has not itself unambiguously resolved the precise substantive issue, then we are to assume that it either "explicitly" or "implicitly" delegated to the agency the interpretive task. ${ }^{71}$ Apparently, this pre-

drafting; indeed, one of the ironies of Chevron is that, in the name of vindicating the primacy of the legislature, it adopts a standard of statutory clarity and specificity that will be difficult for Congress to meet. As Professors Stewart and Sunstein have noted in a different context: "If a judge insists that the sovereign use a particular verbal formula to confer authority, he restricts the sovereign's lawmaking authority by precluding other approaches, such as reliance on background understandings. Touted as a safegnard against usurpation, the formalist thesis in this sense itself leads to usurpation." Stewart \& Sunstein, Public Programs, Private Rights, 95 Harv. L. Rev. I195, 1230-31 (1982) (footnotes omitted).

68. At least one commentator has suggested that this was the case with the bubble concept at issue in Chevron. See Landau, supra note 25, at 295. For an example in the Natural Gas Policy Act of 1978, see Ginsburg, supra note 56, at 998.

69. A good example of this scenario, involving the dollar value of the food stamp monthly allotment, is described in McGowan, supra note 59, at $1129 \mathrm{n} .41$.

When a substantive issue brings Congress to the point of political impasse, the decision to leave the issue unresolved (or, what is effectively the same, to deal with it in deliberately ambiguous terms) may be accompanied by a legislative expectation that resolution will come in time from the agency, or from the courts. In other words, political impasse could generate the interpretive intent of either scenario one or two. It is as likely, however, that impasse will be recognized (and the decision to avert it by avoidance will be made) in the last stages of the legislative process without confronting-let alone deciding-the question of exactly how the issue should eventually be resolved.

70. Even those who disagree on the appropriate interpretive model generally concur that Congress rarely is explicit about its interpretive intent. See, e.g., L. Jaffe, supra note 2, at 570; Breyer, supra note 16, at 369; Diver, supra note 2, at 570; Monaghan, supra note 2 , at $31 \mathrm{n} .184$; see also $4 \mathrm{~K}$. Davis, supra note $2, \S 30.10$ at 252 ("[T]he notion that some powers are by statute committed to administrative discretion is usually unsupported by statutory language or by specific legislative history.").

71. Although Chevron does not use the term "presumption," the opinion treats a finding of statutory silence or ambiguity as sufficient to trigger a conclusion of congressional intent to allocate the interpretive authority to the agency:

If, however, the court determines Congress has not directly addressed the precise question at issue, the court does not simply impose its own construction on the statute, as would be necessary in the absence of an administrative interpretation. Rather, if the statute is silent or ambiguous with respect to the specific 
sumption-that ambiguity equals legislative intent to empower the agency-is irrebuttable. ${ }^{72}$

Perhaps Chevron cannot be faulted for resorting to the device of a presumption. Given the predictable difficulty of making individualized determinations of the state of legislative intent for each new question of statutory meaning, even a court dedicated to vindicating Congress's interpretive will might be forgiven for selecting the model of statutory interpretation according to which of the four scenarios most commonly occurs. The problem is that, even though there is no a priori connection between substantive ambiguity and interpretive intent, Chevron offers no evidence to support its conclusion that silence or unclarity in a regulatory statute typically represents Congress's deliberate delegation of meaning-elaboration power to the agency. ${ }^{73}$ If conclusions about the "typical" legislative will are going to be based on nothing more

issue, the question for the court is whether the agency's answer is based on a permissible construction of the statute.

"The power of an administrative agency to administer a congressionally created ... program necessarily requires the formulation of policy and the making of rules to fill any gap left, implicitly or explicitly, by Congress." If Congress has explicitly left a gap for the agency to fill, there is an express delegation of authority to the agency to elucidate a specific provision of the statute by regulation. Such legislative regulations are given controlling weight unless they are arbitrary, capricious, or manifestly contrary to the statute. Sometimes the legislative delegation to an agency on a particular question is implicit rather than explicit. In such a case, a court may not substitute its own construction of a statutory provision for a reasonable interpretation made by the administrator of an agency.

Chevron, 467 U.S. at $843-44$ (footnotes and citations omitted); see also Scalia, supra note 12 (describing Cheuron as adopting "an across-the-board presumption that, in the case of ambiguity, agency discretion is meant"). Notably, there is no place in this typology for the possibility that Congress intended the judiciary to resolve issues on which it bas not spoken precisely or unambiguously.

72. Justice Stevens's opinion seems to have deliberately shut the door on any arguments over Congress's intent on particular interpretive questions. He says bluntly that, "For judicial purposes, it matters not" whether Congress "consciously desired" the EPA to decide if the bubble concept should be used, whether "it simply did not consider the question at this level," or whether "Congress was unable to forge a coalition on either side of the question." Id. at 865. See generally Strauss, supra note 21, at 1120 (arguing that Chevron appears to reach the conclusion that the agency has been empowered to say what the statute means "as a general imperative of judicial behavior, unconnected to congressional wishes reflected in any given law").

73. Subsequent statements from members of the Court on this point have not improved the ipse dixit quality of Cheuron's treatment. For example, Justice Scalia, countering Justice Brennan's argument that deference should not be accorded an agency's interpretation of a statute confining the scope of its jurisdiction, has opined: "Congress would naturally expect that the agency would be responsible, within broad limits, for resolving ambiguities in its statutory authority or jurisdiction. Congress would neither anticipate nor desire that every ambiguity in statutory authority would be addressed, $d e$ novo, by the courts." Mississippi Power \& Light Co. v. Mississippi ex rel. Moore, $108 \mathrm{~S}$. Ct. 2428, 2444 (1988) (Scalia, J., concurring in the judgment) (citation omitted). His only support for this remarkable assertion is a "cf." cite to Cheuron. 
than intuition, many observers would opine that Congress rarely formulates an intent about who will decide particular questions of statutory meaning. ${ }^{74}$ If they are correct, then the choice between the two interpretive models cannot sensibly be framed as a matter of obeying or defying the legislative will.

If we want to move beyond intuition, solid evidence of what, if anything, Congress "typically" intends with respect to statutory interpretation is hard to come by. Some commentators have urged that Congress's choice of "inherently broad" language in many regulatory statutes raises an inescapable inference of legislative intent to delegate the power of meaning elaboration to the agency. ${ }^{75}$ Others-even including some who generally advocate the deferential model-have disapproved such an inference, ${ }^{76}$ and the presence of equally expansive language in statutory schemes committed to judicial oversight would seem to undermine any notion of some generic legislative disinclination to trust courts with interpreting broad statutory mandates. ${ }^{77}$ Another aspect of regulatory statutes that could conceivably be relevant is the frequently included catchall authorization to make all rules and orders necessary for carrying out the purposes of the act. ${ }^{78}$ Such a provision obviously manifests a legislative judgment that the agency should have considerable discretion to flesh out the regulatory scheme. From the fact that so much power was given, some observers would deduce that the grant of full interpretive authority was intended. ${ }^{79}$ Others con-

74. See, e.g., Breyer, supra note 16, at 369, 376; Levin, Identifying Questions, supra note 2, at 22 n.129; Scalia, supra note 12 .

75. E.g., Note, supra note 21 , at $1000,1002$.

76. E.g., L. Jaffe, supra note 2 , at $560-62,572$ (criticizing setting the mode of review by the "breadth" of the statutory language because "[d]iscretion . . . is not selfdefining; it does not arise parthenogenetically from 'broad' phrases"); see also Levin, Administrative Discretion, Judicial Review, and the Gloomy World of Judge Smith, 1986 Duke L.J. 258, 261 ("It is unhealthy to assume, even as a theoretical starting point, that agencies that possess [a broad grant of authority] should generally be free to behave exactly as they please.") (footnote omitted).

77. The classic example of a broad mandate committed to judicial elaboration and enforcement is the Sherman Act's prohibition of "[e]very contract, combination ... , or conspiracy, in restraint of trade" and of activities that "monopolize, or attempt to monopolize . . . any part of the trade or commerce among the several States." 15 U.S.C. $\$ \S 1-2$ (1982); see also 42 U.S.C. $\$ 2000 \mathrm{e}-2$ (1982) (federal cause of action to remedy "discriminat[ion] against any individual with respect to his compensation, terms, conditions, or privileges of employment, because of" race, gender, religion or national origin); 20 U.S.C. $\$ \$ 1401-1420$ (1982 \& Supp. IV 1986) (federal right of action to enforce handicapped children's right to "free appropriate public education").

78. See, e.g., 15 U.S.C. $\$ 46(\mathrm{~g})$ (1982) (Federal Trade Commission Act); 47 U.S.C. $\S 303(\mathrm{r})$ (1982) (Federal Communications Act).

79. See, e.g., Woodward \& Levin, supra note 10, at 339.

Prior to Cheuron, the courts' search for legislative intent to delegate the power to declare meaning frequently took place under the rubric, advocated by K.C. Davis, of whether an agency had been given "legislative rule-making" power (the authority to make rules with the force of law) or merely "interpretive rule-making" power (the authority to use the procedure of rule making to formulate and express its nonbinding 
clude that the matter cannot be resolved so simply. For example, Judge Stephen Breyer, working within the tradition of Louis Jaffe, has argued that the enactors' interpretive intent is likely to have varied, even within a single regulatory statute, depending on the importance of a given question to the administrative scheme, the nature of the substantive issues involved, and the ability and orientation of the particular agency. ${ }^{80}$

If the statutory provisions that establish administrative systems are dubious barometers of Congress's interpretive intent, we might look to places where the legislature has spoken directly of the judiciary. Regulatory statutes almost always provide for judicial review. 81 Occasionally, these provisions expressly distinguish between the treatment of legal and factual questions. ${ }^{82}$ More often, though, they are silent about the details of review, leaving the court to follow the general command of section 706 of the Administrative Procedure Act (APA) to "decide all

views on regulatory issues). See $2 \mathrm{~K}$. Davis, Administrative Law Treatise, $\S \S 7.8-.11$ (2d ed. 1979 \& Supp. 1982). Chevron's articulation of the deferential model appears to be indifferent to the "legislative"/"interpretive" rule construct. See language quoted supra note 71, and note the linkage of "express delegation" with "legislative regulations" and "implicit" delegation with agency "interpretations." Although lower court practice has not been uniform on the point, the Chevron model is being applied indiscriminately to both legislative and interpretive rules. See Anthony, supra note 12, at 130.

80. Breyer, supra note 16 , at 370 . Judge Breyer readily admits that the "interpretive intent" courts effectuate by looking to such practical considerations is, at bottom, a presumed generic congressional desire that the interpretive power be allocated between court and agency in whatever way "makes sense" for the particular interpretive question. Id. at 368-72. Some commentators are quick to conclude that the most sensible allocation will almost always counsel deference to the agency's view. E.g., Nathanson, supra note 19, at 491; Starr, supra note 16, at 309-11. One of the central difficulties encountered by utilitarian analyses of the relative interpretive competence of courts and agencies is to construct a set of generally accepted criteria for measuring "good" interpretive performance. See Diver, supra note 2, at 573. Regardless of how one structures the utilitarian calculus, however, a generalized congressional partiality for interpretation to be conducted in the "best" possible manner can hardly be equated, for purposes of deciding whether the choice of interpretive model involves defiance of the legislative will, with a congressional "intent" that agencies (or courts) should generally hold the interpretive power.

81. See H.R. Rep. No. 1656, 94th Cong., 2d Sess. 5, reprinted in 1976 U.S. Code Cong. \& Admin. News 6121,6125 ("For years almost every regulatory statute enacted by Congress has contained provisions authorizing Federal courts to review the legality of administrative action that has adversely affected private citizens."); see also Strauss, supra notê 21, at 1114 (noting the "nearly universal provisions . . . for judicial review" and suggesting that these "transfer to the courts some part of the obligation to produce consistent and coherent results" under regulatory legislation). When regulatory statutes themselves do not refer to judicial review, section 10 of the Administrative Procedure Act, 5 U.S.C. $\S \S 701,702,704$ (1982 \& Supp. 1 V 1986), will generally provide a right of review.

82. E.g., 29 U.S.C. $\S 160(f)$ (1982) (providing for review of NLRB decisions and specifying that findings of fact are conclusive so long as supported by substantial evidence in the record as a whole; silent as to standard of review for conclusions of law or policy). 
relevant questions of law, interpret constitutional and statutory provisions," and set aside agency action "in excess of statutory jurisdiction, authority, or limitations, or short of statutory right."83 Prompted by the perception that the New Deal's regulatory fervor had bred a chaotic and unaccountable world of administrative power, the APA represented a conscious congressional determination to strengthen judicial control over the administrative system. ${ }^{84}$ Should we therefore take section 706 at face value, as reflecting a general legislative understanding that courts would independently resolve questions of statutory meaning?85 Or are we to attribute to the enactors of section 706 the far subtler expectation that a reviewing court would frequently "interpret ... statutory provisions" to mean "The agency shall decide what this means?"86 As Ronald Levin has noted, the APA's directions on statutory interpretation have generally "been ignored or dismissed as unreliable." 87 In 1975 Senator Dale Bumpers set out to change all that and

83. 5 U.S.C. $\$ 706$ (1982).

84. See, e.g., H.R. Rep. No. 1149, 76th Cong., 1st Sess. 2 (1939), reprinted in Senate Comm. on the Judiciary, Administrative Procedure Act: Legislative History, S. Doc. No. 248, 79th Cong., 2d Sess. 244 (1947) ("[T] he law must provide that the governors shall be governed and the regulators shall be regulated, if our present form of government is to endure."); S. Rep. No. 752, 79th Cong., 1st Sess. 31 (1945), reprinted in Senate Comm. on the Judiciary, supra, at 217 ("Judicial review is of utmost importance.... It is indispensable since its mere existence generally precludes the arbitrary exercise of powers or assumption of powers not granted.").

In 1937, a committee appointed by President Roosevelt described the executive branch as having "grown up without plan or design like the barns, shacks, silos, tool sheds and garages of an old farm" and condemned the independent agencies as "a headless 'fourth branch' of the Government, a haphazard deposit of irresponsible agencies and uncoordinated powers." President's Comm. on Admin. Management, Report of the Committee with Studies of Admin. Management in the Federal Government 32, 40 (1937). Although a subsequent presidential committee, appointed to study agency functioning and propose procedural reforms, was somewhat more temperate in its views (at least in its majority report), see Attorney General's Comm. on Administrative Procedure, Admin. Procedure in Government Agencies, S. Doc. No. 10, 77th Cong., 1st Sess. (1941), the rhetoric of the earlier report colored the legislative debate that culminated in passage of the APA in 1946. See McGowan, supra note 1, at 223 \& n.32; Sunstein, supra note 5 , at 289 n.96.

85. That section 706 appears to contemplate de novo judicial determination of questions of statutory meaning is generally acknowledged. See, e.g., $4 \mathrm{~K}$. Davis, supra note 2 , $\S 30.01$, at 190; Panel Discussion, supra note 12, at 368 (comments of Professor Sunstein); Pierce \& Shapiro, supra note 58, at 1182; Strauss, supra note 21, at 1120. This reading is supported by the section's failure to distinguish in any way between the interpretation of constitutional and statutory provisions, the former of which has always been subject to independent judgment. See infra note 99 and accompanying text.

86. Ronald Levin has pointed out that "this constrnction reduces the relevant language of $\S 706$ to an unsatisfying circularity. It is as though the statute provided that 'the reviewing court shall decide issues that a reviewing court must decide.' " Levin, Identifying Questions, supra note 2, at 13 n.76. Professor Levin nevertheless goes on to argue that "this does not render the suggested interpretation implausible, because a number of other APA provisions have the same question-begging quality." Id.

87. Id. at 3. 
to "restore the courts to their normal law-interpreting and law-applying role." 88 Over the next seven years, he gathered ever-increasing support among his colleagues for his crusade to amend section 706 expressly to require courts to decide all questions of law "de novo" or "independently." 89 Reported favorably by the House and Senate Judiciary Committees, ${ }^{90}$ and endorsed by the Senate's ninety-four to zero vote, ${ }^{91}$ Bumpers's amendment just missed passage when the larger regulatory reform bill of which it was part died in the "intense political maneuvering during the closing days of the Ninety-Seventh Congress." 92 In gauging Congress's general disposition towards the allocation of the interpretive authority, should we focus on the fact that Bumpers's efforts ultimately failed or on the fact that they so nearly succeeded?

If we can find no certain evidence of Congress's "typical" interpretive intent either in the form and content of regulatory statutes themselves or in the APA and its legislative background, we might turn, finally, to larger theoretical models of the legislative process. Landes and Posner's economic analysis of the relationship between the legislature and the courts posits that Congress relies upon an independent judiciary to enforce the original terms of statutes because the certainty of such enforcement, over time, will enhance the value of any given legislative deal to the interest groups who are bidding for it. ${ }^{93}$ By contrast, Congress perceives agencies to be fairly responsive to current political preferences. ${ }^{94}$ Therefore, Landes and Posner hypothesize,

88. 121 Cong. Rec. 29,957 (1975).

89. For a comprehensive description of the contents of the Bumpers Amendment at various stages in its history, see O'Reilly, Deference Makes a Difference: A Study of Impacts of the Bumpers Judicial Review Amendment, 49 U. Cin. L. Rev. 739 (1980). In contrast to its relatively uncontroversial and increasingly favorable reception by members of Congress, Bumpers's proposal generated vigorous and deeply divided reactions among judges, legal scholars, practitioners, and the agencies themselves. For a sampling of these, see McGowan, supra note 59, at 1162-68; O'Reilly, supra, at 788-90; Woodward \& Levin, supra note 10 , at $330-31$.

90. See O'Reilly, supra note 89 , at 744 (discussing Senate Committee's adoption in 1980); H.R. Rep. No. 435, 97th Cong., 2d Sess. (1982) (report of House Committee adopting somewhat different version).

91. 128 Cong. Rec. S2693-2722 (daily ed. Mar. 24, 1982).

92. Levin, ldentifying Questions, supra note 2, at 3 n.10, 7-8.

93. Landes \& Posner, The Independent Judiciary in an Interest-Group Perspective, 18 J.L. \& Econ. 875, 878-85 (1975). Not surprisingly, Landes and Posner's ultimate conclusion-that serving as the legislature's deal-enforcer is the judiciary's intended function in the constitutional scheme-has proven controversial. Compare Macey, supra note 55, at 240-56 (generally critical) with Easterbrook, supra note 65, at 14-18, 42-60 (generally approving). However, the model's utility as a description of typical legislative expectations exists apart from any normative judgment about whether it is constitutionally intended or appropriate for courts to fulfill those expectations.

94. Landes \& Posner, supra note 93, at 887-88. The extent to which agencies are in fact responsive to direction by the political process is discussed infra in notes 217-51 and accompanying text. 
Congress will entrust a statute's administration to an agency, rather than to the courts, when it wants a more politically sensitive implementation.

At first blush, their analysis might suggest that Congress typically intends courts to defer to agency interpretations of regulatory statutes. But, Landes and Posner go on to predict that Congress will generally provide judicial review to ensure that the agency's responsiveness to current political alignments does not cause it to "stray too far from the terms of the legislative 'deal' establishing the regulatory program that the agency administers." 95 Hence, their analysis implies that at least with respect to important questions of statutory meaning-those terms of the legislative "deal" that would have mattered to the original bargainers-Congress typically intends the court rather than the agency to control interpretation. ${ }^{96}$

The accuracy and significance of Landes and Posner's model can, of course, be vigorously debated, but this is precisely the problem shared by all of the "evidence" on Congress's interpretive intent. Despite Chevron's casual equation of ambiguity with a deliberate delegation of power to the agency, we have little basis for divining with any acceptable degree of confidence the legislature's "typical" expectation regarding the role of courts and agencies in determining statutory meaning. This uncertainty creates a serious dilemma if interpretive intent is the constitutional touchstone for setting the mode of statutory interpretation. Cheoron's fear that independent judgment will impinge on agencies' designated sphere of activity is justified only if Congress generally wishes agencies to have the principal power to resolve statutory ambiguity. If, instead, Congress typically expects courts to exercise this responsibility-not an implausible reading of admittedly ambignous data-then deference represents an equally objectionable failure to implement the legislature's intent. ${ }^{97}$ Finally, if Congress

95. Id. at 888 . This hypothesis is consistent with the observation that Congress virtually always provides expressly for judicial review of administrative action. See supra note 81 and accompanying text.

96. Cf. Panel Discussion, supra note 12, at 365-66 (comments of Judge Starr) (noting that Congress has scarce resources and that it may not respond to agency interpretations with new legislation because it is "counting on the courts, when the interpretation of the agency mandate gives rise to an actual case or controversy, to vindicate Congress's original intent.").

97. See, e.g., Anthony, supra note 12, at 131 (arguing that deference where Congress did not deliberately delegate interpretive power to agencies "might ... profoundly frustrate the expectations of Congress, which until now has probably assumed that it will be the courts that interpret its acts"); Sunstein, supra note 5, at $282 \mathrm{n.59}$ ("Often Congress intentionally leaves issues open for judicial resolution; if courts are to be faithful to the 'deal' itself, statutory silence should not be read as a negation of judicial authority.").

A more subtle problem of failure to implement the legislative will could occur if Congress intended to resolve the substantive issue itself but failed to sigual that answer clearly. Were one entity (court or agency) more likely than the other to decipher the 
often has no focused or consistent idea about who will determine statutory meaning, then attempting to tune the model of interpretation to the legislative will is quixotic at best.

The dilemma is a serious one if the constitutional touchstone is congressional intent. The proposition that Congress is unqualifiedly free to give agencies the power to declare statutory meaning-the second critical assumption of the "judicial usurpation" argumentproves, on close examination, to be as troublesome as the assumption that Congress in fact generally intends to do so.

\section{B. Constraints on the Allocation of Interpretive Power}

It is surely a far more remarkable step than Chevron acknowledged to number among Congress's constitutional prerogatives the power to compel courts to accept and enforce another entity's view of legal meaning whenever the law is ambiguous. ${ }^{98}$ After all, when the law to be interpreted is the Constitution, Congress's view of the appropriate level of judicial scrutiny receives little weight-and mainstream doctrine does not perceive this to be the behavior of a rogue judiciary defying legislative primacy and undermining separation of powers. ${ }^{99}$ Some

garbled signal correctly, then a decision to place primary interpretive responsibility in the hands of the other could be characterized as a threat to implementation of the legislature's will. Colin Diver's utilitarian assessment concludes that "to the extent that differences [between court and agency] in lawfinding capacity appear, they rarely push uniformly in one direction." Diver, supra note 2, at 592. However, Professor Diver's analysis does not take account of the fact that Cheoron, when it defers to the agency on encountering ambiguity, does not also charge the agency with an obligation to seek out and attempt to implement the will of the enactors. Rather, Chevron actively encourages the agency to adopt and further the policy agenda of the current President. See Chevron, 467 U.S. at 865, quoted infra text accompanying note 251. Thus, Chevron's formulation of deference both increases the frequency with which Congress will be perceived to have sent a garbled signal, see supra note 67 , and decreases the agency's motivation to decipher it.

98. One way to appreciate the magnitude of the step is to imagine that Congress enacts a statute requiring the Supreme Court to defer to the view of Solicitor General whenever it encounters an unclear point of federal law. Most members of the legal community would doubtless find such legislation deeply problematic even if it contained the qualification that the Solicitor General's position must be "reasonable" to qualify for deference.

99. Sunstein, In Defense of the Hard Look: Judicial Activism and Administrative Law, 7 Harv. J.L. \& Pub. Pol'y 5 1, 52-54 (1984); Monaghan, supra note 2, at 7-10. The contrary view-that the Court should defer to the conclusion of another branch (in particular, Congress) on the meaning of the Constitution-was most fully developed by James Thayer. See Thayer, The Origin and Scope of the American Doctrine of Constitutional Law, 7 Harv. L. Rev. 129 (I893). Although Thayer strongly influenced the jurisprudence of Felix Frankfurter, see M. Perry, The Constitution, the Courts, and Human Rights 19, $176 \mathrm{nn} .60-61$ (1982), his views have had little lasting impact on constitutional theory. The contemporary debate argues about the materials on which the Court's judgment should be based, compare, e.g., Bork, Neutral Principles and Some First Amendment Problems, 47 Ind. L.J. 1, 8 (1971) (arguing that the only legitimate materials are "the text and the history, and their fair implications") with, e.g., M. Perry, 
commentators have argued, however, that the interpretation of statutes, particularly regulatory statutes, stands on a different footing. Professor Monaghan has stated the position most forcefully: "[O]nce the delegation of law-making competence to administrative agencies is recognized as permissible, judicial deference to agency interpretation of law is simply one way of recognizing such a delegation." 100

At the threshold, this nonchalant classification of law interpretation as simply a species of lawmaking is troubling. Its logical implication-that what courts, the archetypal interpreters, do when they construe a law is really no different than what legislatures, the archetypal lawmakers, do when they create a law-looks wondrous strange against the backdrop of our 200-year legal tradition. Our mainstream political thought has always included the belief that there is and should be a real distinction between making law and interpreting law. ${ }^{101}$ While conceding that the dividing line may be elusive in particular cases, we have nonetheless insisted that officials in all branches of government frame their actions to respect the line's existence. To abandon that insistence now not only paves the way for agencies to obtain the power to resolve statutory ambiguity; it also invites them to wield this power in the mind-set of the Lawmaker, who recognizes only the obligation to be

supra, at 91-145 (arguing that, at least in human rights cases, Court should candidly engage in moral dialogue about "right answers"), but even in its most conservative aspect generally assumes that this judgment will be formulated independently of the views of the other branches. Notably, the one caveat the Court has made to Chevron is that it will not defer to an agency interpretation that would raise serious constitutional questions. See Edward J. DeBartolo Corp. v. Florida Gulf Coast Bldg. \& Constr. Trades Council, 108 S. Ct. 1392, 1397 (1988) (explaining this limitation on deference as an application of the principle that statutes are to be construed to avoid constitutional problems unless such construction is itself plainly contrary to congressional intent).

100. Monaghan, supra note 2, at 7; see also Levin, ldentifying Questions, supra note 2 , at $20-21$.

101. See, e.g., M. Vile, Constitutionalism and the Separation of Powers 21 (1967) ("There is an essential connection between the notion of government according to law and the concept of the functions of government .... Government according to law presupposes at least two distinct operations, the making of law, and putting it into effect."). According to at least one faction in the ongoing linguistic, philosophical and jurisprudential debates about the nature of the act of interpretation, the belief that the two can be distinguished is mere delusion. See supra note 61. Even if that be so, the power of myth to shape individual and communal conceptions of appropriate behavior rarely depends on how accurately it describes reality:

The importance of myth, and its value, lies not in its superficial truth or falsity,

but in the cultural understandings that it represents and the effectiveness with which it represents them. The simple fact that something is a myth-that it does not reflect an historically accurate or objectively verifiable reality-is not a sufficient reason to reject it .... Myth, with all its incongruity and contingency, is the stuff of which culture is made, and culture is the raw material of the law. Williams, The Uses of Myth: A Response to Professor Bassett, 4 J.L. \& Religion 153, 153-54 (1986). For examples of the power of myth to shape public policy see R. Pearce, Savagism and Civilization (rev. ed. 1988); Bassett, The Myth of the Nomad in Property Law, 4 J.L. \& Religion 133 (1986). 
rational, rather than in the mind-set of the Interpreter, who feels constrained by the ideal of fidelity to the intent and purposes of the law entrusted to her keeping. ${ }^{102}$ Liberating agencies from the precept that statutory interpretation is not a guise for flights into policy making seems a peculiar way to vindicate legislative supremacy.

A defense of deference that would abandon any formal distinction between making and interpreting regulatory law thus has disturbing implications. But the problems with recoguizing an unconstrained legislative prerogative to allocate interpretive authority run deeper still. To conceptualize Congress's ability to delegate power to agencies in absolute, "on-off" terms- - if Congress may give lawmaking authority to agencies, then it may give law-interpreting authority to agencies"deceptively oversimplifies the doctrinal course that sanctioned the growth of administrative agencies. Section 1 traces this course by reviewing the history of the Supreme Court's nondelegation analysis. As it evolved, the nondelegation doctrine came to incorporate a vision of the constitutional relationships between the legislature, agencies and the judiciary fundamentally at odds with Chevron's assumption that Congress may empower agencies to decide what regulatory statutes mean whenever they appear ambiguous.

The Court's apparent unawareness of this inconsistency is itself disturbing, but more is at stake in Chevron than the unheeded demise of an existing line of doctrine. Section 2 briefly traces the origins and nature of the American theory of separation of powers. This section argues that the way in which mature nondelegation analysis reconciled agencies to the constitutional scheme was faithful to separation of powers theory and furthered the purposes which that structural principle was intended to serve. When Chevron asserts that agencies may be given the principal responsibility for defining the statutes under which they function, it not only repudiates a major strand of administrative law doctrine, but also undermines the constitutional reconciliation of regulatory power which that doctrine represented. In other words, while Chevron is right in suggesting that the choice of interpretive model has significant separation of powers implications, it has misperceived what those implications are.

1. The Evolution of Nondelegation Doctrine: From Power Divided to Power Restrained. - In its pristine form, the nondelegation doctrine insists that the legislature may not cede its lawmaking power to another entity. Although the doctrine is not expressly grounded in the text of the Constitution, the Court and most commentators have considered it of constitutional dimension because it appears to be a logical, if not inevitable, corollary of other constitutional norms. ${ }^{103}$ Chief among

102. Chevron does not require agencies to resolve ambiguity by attempting to discern and effectuate the will of the enacting legislature, but instead encourages them to choose a "meaning" that reflects the wishes of the current President. See supra note 97.

103. See, e.g., J.W. Hampton, Jr., \& Co. v. United States, 276 U.S. 394, 406 (1928) 
these is the principle of separation of powers. ${ }^{104}$ If the legislature were permitted to transfer its power to another part of government, the Constitution's efforts to render governmental power safe by dividing it among discrete power centers could easily be frustrated. Hence, to the extent that the nondelegation doctrine is called upon to help enforce the structural commitment to separation of powers, its principal focus is the movement of power: is the authority of one branch being transferred to another, which will now possess a dangerous concentration of government power? ${ }^{105}$

Nondelegation doctrine served as one of the principal battlegrounds upon which the constitutionality of the growth of federal regulatory authority was tested. ${ }^{106}$ Obviously, the doctrine did not long survive in its pristine form. The size and power of the contemporary administrative state became doctrinally possible because the Supreme Court's view of the scope and purpose of constitutional restraints on delegation evolved considerably during the nineteenth and early twentieth centuries. The "failure" of the Court's nondelegation

("it is a breach of the National fundamental law if Congress gives up its legislative power and transfers it to the President, or to the Judicial branch"); Field v. Clark, 143 U.S. 649,692 (1892) ("That Congress cannot delegate legislative power . . . is a principle universally recognized as vital to the integrity and maintenance of the system of government ordained by the Constitution."); S. Barber, The Constitution and the Delegation of Congressional Power 11-41 (1975).

104. See generally S. Barber, supra note 103 , at 24 (nondelegation is more frequently linked with separation of powers than with any other concept).

105. The other generally acknowledged constitutional root of the nondelegation doctrine is the commitment to preserving representative democracy, discussed infra notes 254-69 and accompanying text, as the "legitimacy ideal." See, e.g., L. Jaffe, supra note 2 , at 34 (objection to indiscriminate delegation "expresses a fundamental democratic concern"). To the extent that the doctrine is called on to safeguard this constitutional norm, its focus will be on the nature of the power transferred: Are decisions of public policy being made by someone other than those whom the people have chosen as their representatives?

Although the Supreme Court typically links the doctrine to separation of powers and the legitimacy ideal, see, e.g., Industrial Union Dep't v. American Petroleum Inst., 448 U.S. 607, 672-74 (1980) (Rehnquist, J., concurring in the judgment), commentators have suggested other possible constitutional antecedents in due process and the rule-oflaw norm, or in the overarching principle of constitutional supremacy. See generally $S$. Barber, supra note 103, at 11-13, 30-36 (collecting views and sources). Finally, a minority of commentators, most notably K.C. Davis, have insisted that the doctrine is a spurious judicial invention with no true constitutional character. See $1 \mathrm{~K}$. Davis, supra note $2, \S 2.02$, at 79 . For others who have shared this view, see S. Barber, supra note 103 , at 12 .

106. The other, of course, was substantive due process. Although both represented potential doctrinal obstacles to the emergence of the administrative state, one was primarily ends-oriented while the other primarily means-oriented. Substantive due process questioned the scope of federal power to intervene in the nation's economic and social order, with little concern over whether intervention was accomplished by Congress directly or by some other arm of the national government; nondelegation attacks assumed the existence of federal power over the subject matter, but challenged the attempt to exercise such power through the executive branch or an independent agency. 
analysis to halt, or even slow, Congress's drive towards ever more regulatory intervention through ever more delegation of policy-making power has led many to dismiss the doctrine as an empty exercise in judicial rhetoric. These commentators regard the line of nondelegation cases as little more than high-sounding hocus-pocus, in which the Court mutters beguiling incantations while blowing smoke in the face of statutory reality-all in order to create the illusion of a judiciary zealously safeguarding the Constitution, while the legislature blithely does as it pleases. ${ }^{107}$ It is of course possible that the series of cases discussed below ought to be dismissed as merely an elaborate charade, a ritual of approval that never had substance save for an interval in the 1930s when nondelegation allowed the Court a brief victory in a political war it ultimately lost. However, no one has convincingly explained why a Court that has repeatedly been willing, from Marbury $v$. Madison ${ }^{108}$ to Bowsher v. Synar, ${ }^{109}$ to brave political controversy by telling Congress it has gone too far would choose to engage-for well over a century and through Justices as diverse as Marshall, Harlan, Taft, Cardozo and Stone ${ }^{110}$-in whitewashing Congress's delegative propensities.

The discussion that follows therefore takes the nondelegation cases seriously. Perhaps more accurately, it takes seriously the idea that these cases chronicle the Court's purposeful struggle to construct, if possible, a constitutional model for the administrative state that would enable Congress to use means it deemed necessary to pursue ends it deemed appropriate, without sacrificing ideas and forms central to the Constitution. ${ }^{111}$ Ultimately, a model emerged that reconciled the vesting of vast regulatory authority in agencies with the principle of separation of powers. ${ }^{112}$ But this reconciliation was not without some terms

107. For example, in two of the most detailed exegeses of the area, Sotirios Barber describes nondelegation doctrine as "heavily encrusted with the constructs of judicial myth-making" and revealing "a judicial propensity to manipulate well-rehearsed formulas for upholding delegations of any kind," S. Barber, supra note 103, at 62, 76, while Louis Jaffe finds the Court's reasoning at various stages "hopelessly fictional rationalization" and "sheer illusion." L. Jaffe, supra note 2, at 51, 56. Probably the most caustic commentary on the Court's nondelegation analysis comes from K.C. Davis. See K. Davis, supra note $2, \S 2.01-.02$. $1787)$.

108. 5 U.S. (1 Cranch) 137, 177 (1803) (invalidating portions of the Judiciary Act of

109. 478 U.S. 714,726 (1986) (striking down a central feature of the GrammRudman-Hollings Balanced Budget Act).

110. See cases discussed supra notes 113-49 and accompanying text.

111. Thus, I do not mean to deny that the Court's characterization of the operation and effects of the statutes involved in the nondelegation cases at times reflected naiveté, wishful thinking, perhaps even self-delusion. My point, rather, is that the cases represent a conscientious-if you will, good faith-effort to conform the apparently round peg of growing administrative governance into the seemingly square hole of constitutional theory. That the "fit" often had to be massaged, and never was perfect, simply underscores the extraordinary difficulty of the undertaking.

112. And, perhaps less successfully, with the legitimacy ideal. See infra, notes 254-69 and accompanying text. 
and conditions-certain caveats on how Congress could structure this new configuration of government power which, unless the Justices were knaves or fools, were thought to be essential to the constitutional reconciliation and were therefore intended to be respected.

The foundation of the Court's nondelegation analysis was laid in nineteenth century cases challenging congressional grants of authority, not to agencies, but to the other two branches. Wayman $v$. Southard ${ }^{113}$ attacked a provision of the Process Act of 1792 that permitted the Supreme Court to promulgate rules for the service of process and execution of judgments in the federal courts. ${ }^{114}$ Writing for the Court, Justice Marshall readily agreed with the petitioners that Congress could not delegate "powers which are strictly and exclusively legislative." 115 He concluded, however, that the Act did not involve such delegation. While declining to undertake the "delicate and difficult inquiry" of defining the "precise boundary" of undelegable, "legislative" power, 116 Marshall suggested that the gravity of the subject matter was a key factor:

The line has not been exactly drawn which separates those important subjects, which must be entirely regulated by the legislature itself, from those of less interest, in which a general provision may be made, and power given to those who are to act under such general provisions, to fill up the details. ${ }^{117}$

The Process Act was constitutional because it delegated merely "a power to vary minor regulations, which are within the great outlines marked out by the legislature."118 Near the end of the century, the "legislative"/ "nonlegislative" distinction was again invoked, this time to sustain a delegation to the President. Justice Harlan's analysis in Field v. Clark ${ }^{119}$ began, as Marshall's had, by firmly endorsing the nondelegation doctrine. ${ }^{120}$ Harlan was more willing than Marshall, however, to attempt to define the critical term "legislative power." Legislating, he explained, means determining what is wise or expedient, rather than merely implementing a previous policy decision. ${ }^{121}$ The statute at issue provided that a certain tariff would take effect if the President determined that the country of origin imposed "reciprocally unequal and unreasonable" tariffs on American goods. ${ }^{122}$ Harlan reasoned that "[n]othing involving the expediency or the just operation"

113. 23 U.S. (10 Wheat.) 1 (1825).

114. In the absence of such rules, federal courts were directed to follow the process laws of the state in which they were located. Id. at 31.

115 . Id. at 19.

116. Id. at 20.

117. Id. at 19.

118. Id. at 20.

119. 143 U.S. 649 (1892).

120. Id. at 692 , quoted supra note 103 .

121. Id. at 693-94.

122. Id. at 692. 
of the tariff was left to the President's determination. ${ }^{123}$ Congress had specified the goods, fixed the tariff levels, and set the standard that would trigger the scheme; the President was "the mere agent of the law-making department" to investigate and determine the facts upon which the statutory consequences were contingent. ${ }^{124}$

The very formalistic approach of these nineteenth century cases responded directly to the separation of powers root of the nondelegation doctrine. So long as the power delegated was not "legislative," separation of powers in its simplest, literal sense-division of powerwas unthreatened. If the authority being transferred did not look like lawmaking (however this was defined), none of the power characteristic of the legislative branch had seeped into another sector of government, and the tripartite division remained intact.

The Court attempted to carry over this uncomplicated, conceptually pat approach into the early nondelegation attacks on administrative agencies. In United States $v$. Grimaud, ${ }^{125}$ for example, ranchers indicted for grazing sheep on federal land without a permit attacked the statute $^{126}$ that broadly empowered the Secretary of Agriculture to regulate use of the public forests "for the protection against destruction by fire and depredations." 127 The Court followed the well-established course of emphasizing that legislative power could not be delegated but noting that not all power delegated was legislative in nature. ${ }^{128}$ The statute at issue here did not fit the Field pattern of a full-blown, congressionally defined regulatory scheme awaiting merely the delegee's determination that a predefined set of conditions had come about. Hence, Field's contingency rationale could not save the delegation to the Secretary as "nonlegislative." The Court did find help, however, in Marshall's earlier formulation. Quoting Wayman it explained: "[W]hen Congress had legislated and indicated its will, it could give to those

123. 1d. at 693 .

124. Id. In so reasoning, Justice Harlan relied upon an earlier tariff case, The Brig Aurora, 11 U.S. (7 Cranch) 240 (1813), in which the challenged delegation directed that certain import restrictions would be revived upon the President's declaration that either France or Great Britain had ceased to violate the neutral commerce of the United States. To make revival of a law dependent on presidential proclamation, the appellant argued, impermissibly gave a presidential act the effect of law. Id. at 242. The appellee responded that the legislature had not transferred legislative power, but rather had merely "prescribed the evidence which should be admitted of a fact, upon which the law should go into effect." Id. at 243. The Court, apparently accepting the latter characterization, tersely remarked that it saw no reason why Congress "should not exercise its discretion in reviving the act ... either expressly or conditionally, as their judgment should direct." Id.

125. 220 U.S. 506 (1911).

126. Act of Feb. 1, 1905, Pub. L. No. 34, ch. 288,33 Stat. 628 (codified as amended in scattered sections of 16 U.S.C.).

127. Act of June 4,1897 , ch. 2,30 Stat. 11,35 (codified as amended at 16 U.S.C. $\S 551$ (1982)), quoted at 220 U.S. at 509.

128. 220 U.S. at $517,521$. 
who were to act under such general provisions 'power to fill up the details' by the establishment of administrative rules and regulations."129

The crux of the early, formalistic approach to nondelegation was, of course, distinguishing "legislative" from other types of power. 130 The tariff statute in Field was conceptually fairly easy. ${ }^{131}$ Finding the facts upon which certain preordained legal consequences attend is not the legislator's typical province. ${ }^{132}$ The Process Act in Wayman was somewhat more difficult, although the ability to formulate rules for the operation of the courts seems sufficiently incidental to the judicial power to avoid labelling it intrinsically legislative. ${ }^{133}$ The fairly openended delegation in Grimaud, however, was much more troublesome. In light of Harlan's definition of lawmaking in Field - which emphasized the presence of discretion to determine what is wise or expedient-it becomes difficult functionally to distinguish, from the action of legislators, the Secretary of Agriculture's decisions about whether grazing permits or other measures are needed to protect the public forests. Under the pressure of the broader statutory delegation in Grimaud, the early formalistic analysis began to shift. Nondelegability was coming to turn not simply on the nature, but also on the extent, of the power delegated.

The shift became pronounced in the 1928 case of $J . W$. Hampton, $J r$. $\mathcal{E}^{\circ}$ Co. $v$. United States. ${ }^{134}$ Again the challenged delegation involved presidential administration of a tariff; this time, however, the statute authorized the President, after investigation and hearing by the Tariff Commission, to increase the congressionally established tariff schedule by any amount necessary to "equalize the ... costs of production in the United States and the principal competing country." "135 In upholding

129. 1d. at 517.

130. Professors Aranson, Gellhorn and Robinson point out that part of the Court's strategy in these early cases was narrowly to construe the delegated authority. Aranson, Gellhorn \& Robinson, A Theory of Legislative Delegation, 68 Cornell L. Rev. 1, 7 (1982). This facilitated the formalistic approach.

131. The statute involved in The Brig Aurora was also conceptually easy. See supra note 124.

132. This assumes one is willing to accept that the question whether another country is imposing a reciprocally unequal or unreasonable tariff on American goods is predominantly factual in nature. Louis Jaffe vigorously disputed this proposition, see $\mathrm{L}$. Jaffe, supra note 2 , at 56 , but he also acknowledged the uncertainty and disagreement that has always surrounded attempts to define "factual" questions, id. at 546-47, and the Field Court, simplistically or not, seemed quite comfortable with its characterization.

133. Justice Marshall was careful to point this out: "[The delegated power] is, in all its parts, the regulation of the conduct of the officer of the court, in giving effect to its judgments. A general superintendence over this subject seems to be properly within the judicial province, and has been always so considered." Wayman, 23 U.S. (10 Wheat.) at 20.

134. 276 U.S. 394 (1928)

135. Tariff Act of Sept. 21, 1922, ch. 356, 42 Stat. 858, 941-42 (repealed 1930), quoted at 276 U.S. at 401. 
the statute, the Court announced a new standard for assessing delegability: "If Congress shall lay down by legislative act an intelligible principle to which the person or body authorized to fix such rates is directed to conform, such legislative action is not a forbidden delegation of legislative power." 136 Under the "intelligible principle" standard, the Court during the 1930s upheld several broad statutory delegations ${ }^{137}$ and eventually struck down critical sections of the National Industrial Recovery Act. ${ }^{138}$

With the adoption of "intelligible principle" analysis, the Court no longer conceived the scope of delegable authority as delimited by the bounds of "legislative" power. Although Hampton had resisted calling the delegated power "legislative," even that bow to the formalistic approach rapidly disappeared. By 1933 the Court, through Justice Cardozo, was admitting quite frankly that the tariff provisions upheld in Hampton represented "in substance a delegation, though a permissible one, of the legislative process."139 And even when Panama Refining and Schecter Poultry made history as the first successful nondelegation challenges, the Court framed its discussion not in terms of a simple dichotomy between "legislative" and "nonlegislative" power, but instead as an inquiry into whether the statutory provisions "abdicate or [] transfer to others, the essential legislative functions with which [Congress] is thus vested." 140 In sum, "intelligible principle" analysis conceded that lawmaking authority may be delegated-so long as Congress had made the important policy choices, established the "primary standards."141

136. Id. at 409 .

137. E.g., United States v. Rock Royal Coop., Inc., 307 U.S. 533, 574-77 (1939); Federal Radio Comm'n v. Nelson Bros. Bond \& Mortgage Co., 289 U.S. 266, 285 (1933); New York Cent. Sec. Corp. v. United States, 287 U.S. 12, 16, 24-25 (1932).

138. National Industrial Recovery Act of 1933, ch. 90, 48 Stat. 195. See A.L.A. Schecter Poultry Corp. v. United States, 295 U.S. 495, 541-42 (1935) (section 3 of the Act "supplies no standards for any trade, industry or activity"); Panama Refining Co. v. Ryan, 293 U.S. 388, 430 (1935) (in section 9(c) of the Act, "the Congress has declared no policy, has established no standard, has laid down no rule"). Justice Cardozo, dissenting in Panama Refining, disagreed not with the Court's analytic framework but with its application to the statute. He found in the opening declaration of policy "a sufficient definition of a standard to make the statute valid." Id. at 440 (Cardozo, J., dissenting). A third case, Carter v. Carter Coal Co., 298 U.S. 238 (1936), invalidated parts of the Bituminous Coal Conservation Act of 1935, ch. 824, 49 Stat. 991 (repealed 1937), on the theory that the delegation of wage- and hour-fixing power to private producers and miners violated due process. Id. at 310-11.

139. See Norwegian Nitrogen Prods. Co. v. United States, 288 U.S. 294, 305 (1933), which involved a procedural challenge to a tariff increase imposed under the tariff statute sustained in Hampton.

140. Schecter, 295 U.S. at 529 (quoting Panama Refining, 293 U.S. at 421) (emphasis added). Justice Cardozo's concurring opinion in Schecter underscored the new tolerance for the transfer of power concededly legislative in nature when it began: "The delegated power of legislation which has found expression in this code is not canalized within banks that keep it from overflowing." Id. at 551 (Cardozo, J., concurring).

141. Panama Refining, 293 U.S. at 426. 
Explicitly condoning the transfer of some lawmaking power meant reconceptualizing not only the nondelegation doctrine itself, but also, and more importantly, the principle of separation of powers that the doctrine was invoked to serve. The "intelligible principle" construct no longer permitted even a fiction that division of power was being preserved. The structural metaphor changed. Rather than discrete compartments of scrupulously segregated powers, the edifice of government now appeared as an ordered collection of weight-bearing and subsidiary components: agency decisions were acknowledged to be "indeed binding rules of conduct," but were accepted as "subordinate rules" that existed "within the framework of the policy which the legislature has sufficiently defined." 142 The emphasis was shifting from power divided to power kept in check.

The wartime case of Yakus $v$. United States ${ }^{143}$ marked the completion of this conceptual shift. Under attack was the Emergency Price Control Act of 1942 that, although of limited duration, swept broadly across the economy and allowed the Price Administrator to establish maximum prices for virtually all commodities. ${ }^{144}$ The Court teased out of the statute a set of broad but comprehensible criteria that, it held, governed the Administrator's decisions. ${ }^{145}$ More significant, however, than the content of those criteria or the Court's methods of "finding" them in the statute was its explanation of their relevance to the delegation inquiry. Statutory standards become constitutionally critical, because they make possible an external assessment of the propriety of the delegee's actions:

Only if we could say that there is an absence of standards for the gnidance of the Administrator's action, so that it would be impossible in a proper proceeding to ascertain whether the will of Congress has been obeyed, would we be justified in overriding its choice of means for effecting its declared purpose of preventing inflation. ${ }^{146}$

142. 1d. at 428-29.

143. 321 U.S. 414 (1944).

144. Emergency Price Control Act of Jan. 30, 1942, 56 Stat. 23, as amended by the Inflation Control Act of Oct. 2, 1942, 56 Stat. 765 (terminated and expired 1947); 321 U.S. at 420. The Price Administrator was also empowered to set rents. Id.

145. The Court read the statute to contain a mandate that maximum prices be "fair and equitable," a requirement that they tend to promote the anti-inflationary purposes of the act, and a direction that the Administrator "consider" prices prevailing in a specified base period. Id. at 427 .

146. Id. at 426. Yakus's approval of the Emergency Price Control Act is sometimes cited as evidence of the emptiness of nondelegation analysis. One could as readily insist, however, that the Court's determination to "find" standards through creative statutory construction evidences the persistent vitality of the doctrine. Nondelegation concerns may inform an analysis without producing the ultimate remedy of striking down the statute. Cf. Panama Refining Co. v. Ryan, 293 U.S. 388, 434-41 (1935) (Cardozo, J., dissenting) (construing the statute to contain mandatory standards in order to save the delegation). 
"Intelligible principle" analysis of the 1920 s and 30 s had moved nondelegation theory across the great divide of "legislative" and "nonlegislative" power, but it had continued to focus the constitutional inquiry on the type of policy decisions involved in the delegation. The essential (that is, undelegable) legislative function was to make the important choices, to set the primary standards. The separation of powers objective of avoiding a dangerous concentration of power was honored by insisting that Congress itself establish the policy mainframe, within which its delegee could then be permitted to make merely subordinate rules. Yakus bowed to this earlier rhetoric of "the formulation of subsidiary administrative policy within the prescribed statutory framework," 147 but ultimately recast the delegation issue purely in terms of power control. After Yakus, the constitutionally relevant inquiry is no longer whether Congress resolved certain types of issues, but whether it supplied enough policy structure that someone can police what its delegee is doing:

The standards prescribed by the present Act, with the aid of the "statement of considerations" required to be made by the Administrator, are sufficiently definite and precise to enable Congress, the courts and the public to ascertain whether the Administrator, in fixing the designated prices, has conformed to those standards. Hence we are unable to find in them an unauthorized delegation of legislative power. ${ }^{148}$

In this ultimate reformulation of nondelegation theory, the device through which the people are safeguarded from the danger of tyrannical government force is not division of powers, but external control over power. ${ }^{149}$

The most lucid restatement of mature nondelegation analysis appears in Amalgamated Meat Cutters $\mathcal{E}^{\circ}$ Butcher Workmen of North America v. Connally, ${ }^{150}$ in which a three-judge district court sustained the delegation of price-control power to the President in the Economic Stabilization Act of 1970.151 The line of nondelegation cases, Judge

147. Yakus, 321 U.S. at 425 (citation omitted).

148. Id. at 426 (citation omitted); see also id. at 425 (constitutionality turns on whether the statute "sufficiently marks the field within which the Administrator is to act so that it may be known whether he has kept within it in compliance with the legislative will'). The need for ability to control the delegee may indeed require that Congress make the "important" policy choices; otherwise, the delegee may be unconstrainable in significant areas of power. But the point is that the focus of the analysis has moved away from types of power to control of power.

I49. As the Court explained two years after Yakus: "[It is] constitutionally sufficient if Congress clearly delineates the general policy, the public agency which is to apply it, and the boundaries of this delegated authority. Private rights are protected by access to the courts to test the application of the policy in the light of these legislative declarations." American Power \& Light Co. v. SEC, 329 U.S. 90, 105 (1946).

150. 337 F. Supp. 737 (D.D.C. 1971).

151. Economic Stabilization Act of 1970, Pub. L. No. 91-379, tit. II, 84 Stat. 799 (terminated 1974). 
Leventhal suggested, reduces to a key proposition: "Concepts of control and accountability define the constitutional requirement."152 The issue posed by the delegation of regulatory authority has come to be viewed purely in terms of whether the new allocation of power can be adequately checked: "The claim of undue delegation of legislative power broadly raises the challenge of undue power in the Executive and thus naturally involves consideration of the interrelated questions of the availability of appropriate restraints through provisions for administrative procedure and judicial review."153

The great success with which nondelegation analysis evolved to accommodate a regulation-favoring political consensus has, unfortunately, produced an insidious "bottom-line" myopia-a tendency to focus only on the consequence that Congress may broadly delegate regulatory power, while ignoring the doctrinal construct that developed to make this outcome possible. A belief in legislative primacy obviously occupied an important place in that construct. Congress was accorded great deference to transfer power and thereby radically restructure American government. But the Court's long struggle to reconcile the growth of agencies with the Constitution yielded a solution far more complex than carte blanche for Congress to give agencies whatever power it wishes them to have. The administrative state became constitutionally tenable because the Court's vision of separation of powers evolved from the simple (but constraining) proposition that divided powers must not be commingled, to the more flexible (but far more complicated) proposition that power may be transferred so long as it will be adequately controlled.

A crucial aspect of the capacity for external control upon which the permissibility of delegating regulatory power hinged was judicial policing of the terms of the statute. Again, Judge Leventhal expressed the point most succinctly: "Congress has been willing to delegate its legislative powers broadly-and the courts have upheld such delegationbecause there is court review to assure that the agency exercises the delegated power within statutory limits."154 Whether or not Judge Leventhal correctly interpreted the legislature's motives, ${ }^{155}$ he aptly characterized the course of nondelegation theory in the courts. The constitutional accommodation ultimately reached in the nondelegation cases implied that principal power to say what the statute means must rest outside the agency, in the courts.

Hence, a key assumption of Cheoron's "judicial usurpation" argument-that Congress may give agencies primary responsibility not only

152. 337 F. Supp. at 746 .

153. 1d. at 759; see also McGowan, supra note 59, at 1174 (dealing with agency activities under broadly delegative statutes is a problem of checks and balances).

154. Ethyl Corp. v. EPA, 541 F.2d 1, 68 (D.C. Cir.) (en banc) (Leventhal, J., concurring) (footnote omitted), cert. denied, 426 U.S. 941 (1976).

155. See supra notes $65-97$ and accompanying text. 
for making policy within the limits of their organic statutes, but also for defining those limits whenever the text and surrounding legislative materials are ambiguous-is fundamentally incongruous with the constitutional course by which the Court came to reconcile agencies and separation of powers. Of course, to demonstrate that one of Cheuron's central premises cannot be squared with the doctrinal structure built in the nondelegation cases is not necessarily to establish that this structure was worth preserving. Was it merely a delusion that separation of powers could be honored through a theory of nondelegation that permitted the concentration of great policy-making and executing authority in administrative agencies, but which insisted that agencies could not then also hold the power to say what their organic statutes mean? An examination of the origins and content of that constitutional principle suggests not. The vision of separation of powers embodied in mature nondelegation analysis-a vision that came to ask whether power was being adequately checked, rather than whether powers were remaining divided-was in essence true to the constitutional vision.

2. The Significance of Separation of Powers: Seeking the Balance of Power. - With a lineage that extended back to Classical Greece and included such English political theorists as Locke and Blackstone, the idea of a government structured by the separation of powers came to the Americans principally through the writings of Montesquieu. ${ }^{156}$ His The Spirit of Laws assumed that humans given authority are bound to aggrandize and ultimately abuse it; ${ }^{157}$ societies confront this problem of control-

156. In Federalist 47, for example, Madison invokes "the celebrated Montesquieu" as "the oracle who is always consulted" on the subject of separation of powers, The Federalist No. 47, at 324 (J. Madison) (J. Cooke ed. 1961), a reference Hamilton echoes in his discussion of the judiciary in Federalist 78. See Federalist No. 78, supra note 4, at 523. On Montesquieu's influence on American political theory in the Revolutionary period, see the classic work on separation of powers, $M$. Vile, supra note 101, at 76-97, and in addition Montesquieu, The Spirit of Laws: A Compendium to the First English Edition xiii, 57 (D. Carrithers ed. 1977) [hereinafter Montesquieu Compendium]; G. Wood, The Creation of the American Republic, 1776-1787, at 151-52 (1969); Sharp, The Classical American Doctrine of "The Separation of Powers", 2 U. Chi. L. Rev. 385, 419 (1935).

William Blackstone's Commentaries on the Laws of England was the medium through which Montesquieu's ideas came to many of the colonists. M. Vile, supra note 101 , at 102. To a people who were keenly aware of their unique opportunity to realize political theory by creating a new polity, the "scientific" approach of Montesquieu and Blackstone-both of whom professed an objective and detached observation of the principles of laws and government-was irresistible. See M. Vile, supra note 101, at 76-77; G. Wood, supra, at 6-10. On Montesquieu's methodology, see generally Montesquieu Compendium, supra, at 18-23 (The guiding principle of Montesquieu's work was that "given proper methods and diligence, nearly all social and political phenomena are rationally explicable.").

157. I Montesquieu, The Spirit of Laws, bk. XI, ch. 4, at 161 (T. Nugent trans. 1878) ("constant experience shows us that every man invested with power is apt to abuse it, and to carry his authority as far as it will go"). See generally Montesquieu Compendium, supra note 156, at 72 ("Evident throughout Montesquieu's political writings is a profound distrust of unchecked political power."); $M$. Vile, supra note 101, at 
ling the power to govern by forming constitutions. ${ }^{158}$ The ideal "constitution of liberty," Montesquieu argued, would protect the people from tyranny by dividing governmental power among different organs:

When the legislative and executive powers are united in the same person, or in the same body of magistrates, there can be no liberty; because apprehensions may arise, lest the same monarch or senate should enact tyrannical laws, to execute them in a tyrannical manner.

Again, there is no liberty, if the judiciary power be not separated from the legislative and executive .... .

There would be an end of everything, were the same man or the same body, whether of the nobles or of the people, to exercise those three powers, that of enacting laws, that of executing the public resolutions, and of trying the causes of individuals. ${ }^{159}$

In this passage, Montesquieu described what may be thought of as the "pure" doctrine of separation of powers. The task of governing is divided into conceptually distinct functions, which are then allotted to structurally distinct parts of the government, which are in turn staffed by separate and distinct personnel. ${ }^{160}$ Division, theoretically, ensures safety, for no person or group controls the entire spectrum of government power.

The "pure" doctrine captivated Americans at the time of the Revolution, as they traced the abuses of British rule to an overweening executive (the King) who had become tyrannical by subverting the independence of the legislature (Parliament or, more precisely, the House of Commons)..$^{161}$ The earliest state constitutions, adopted in the months immediately surrounding the Declaration of Independence,

78 (Montesquieu "saw men as exhibiting a general tendency toward evil."). Gordon Wood has noted that distrust of human response to power was a fundamental part of the radical Whig ideology embraced by Americans at the time of the Revolution. G. Wood, supra note 156, at 21-23, 32-33. Even though the Confederation period wrought significant changes in the political theory of the Revolution, this suspicion and fear of power survived. Thus, Madison wrote in Federalist 48: "It will not be denied, that power is of an encroaching nature, and that it ought to be effectively restrained from passing the limits assigned to it." The Federalist No. 48, at 332 (J. Madison) (J. Cooke ed. 1961).

158. See M. Vile, supra note 101 , at 78 .

159. Montesquieu, supra note $157, \mathrm{bk} . \mathrm{XI}, \mathrm{ch} .6$, at 163 . While Montesquieu's ideal constitution took England as its source, it did not exactly replicate the English Constitution that actually existed. Montesquieu Compendium, supra note 156, at 58-59, 77-82; M. Vile, supra note 101, at 84; cf. G. Wood, supra note 156, at 10 14 (at time of the Revolution, the colonists idealized the English Constitution and insisted they were its "true gnardians").

160. Professor Vile refers to this as separation of function, agency, and person. M. Vile, supra note 101 , at 13 .

161. Professor Wood has vividly recounted the colonists' conviction of a "despotic conspiracy against freedom" conducted by the Crown with the assistance of a Parliament it had corrupted through bribery and influence peddling and a corps of royal governors 
were structured to adhere, at least formally, to a strict division of authority. ${ }^{162}$ In particular, the executive was deliberately stripped of powers, including the ability to veto legislation and to appoint government officers, which the King was accused of having employed to reduce Parliament to a servile, corrupted statús. ${ }^{163}$ But experience under these early, divisionist constitutions was disillusioning. The state legislatures not only legislated with what many regarded as irresponsible abandon ${ }^{164}$ but also began to engage, under the guise of lawmaking, in executive and judicial tasks. ${ }^{165}$ Contemporary political observers came increasingly to conclude that these constitutions had unwittingly permitted the emergence of a new species of dangerous concentration of power, this time in the hands of the legislature. ${ }^{166}$ They began to question the efficacy of a structural theory that merely divided power without providing any affirmative mechanism (beyond the refusal of the electorate to reelect individual officials) for restraining a part of government with usurpationist proclivities. ${ }^{167}$

The perceived need for a governmental form that included positive controls against encroachment led American political thought to a second structural theory with ancient roots: the theory of mixed government. Mixed government seeks stability and control through the

who extended Crown influence in the colonies by patronage and manipulation of the colonial legislatures. See G. Wood, supra note 156 , at 33-34, 42, 79, 143-48, 156-58.

162. M. Vile, supra note 101, at 119-20. The principal energy of American political thinkers during this period focused on the state constitutions, for few yet contemplated anything other than a loose confederation on the national level. See G. Wood, supra note 156, at 127-28, 354. Some of these constitutions were "purer" in separation of powers terms than others, and most departed from the pure theory by dividing the legislature into two houses. See id. at 137-41; M. Vile, supra note 101, at 119. Also, their operation in practice often differed considerably from their formal structure. See id. at 119.

163. On the new states' structuring of the executive, "a remarkable and abrupt departure from the English constitutional tradition," see G. Wood, supra note 156, at 135-48.

164. See G. Wood, supra note 156 , at 405-06.

165. Thomas Jefferson, for example, complained of the Virginia legislature: "[The Assembly] have accordingly in many instances decided rights which should have been left to judiciary controversy; and the direction of the executive during the whole time of their session, is becoming habitual and familiar." T. Jefferson, Notes on the State of Virginia 120 (W. Peden ed. 1954), quoted in The Federalist No. 48, supra note 157, at 336-37 (J. Madison) (italics omitted).

On the national level, Alexander Hamilton worried that, under the Articles of Confederation, Congress was both too weak and too inclined, for the power it did have, to "have kept the power too much into their own hands and have meddled too much with details of every sort. Congress is properly a deliberative corps and it forgets itself when it attempts to play the executive." Letter from Alexander Hamilton to James Duane (Sept. 3, 1780), reprinted in 2 Papers of Alexander Hamilton 400, 404 (H. Syrett \& J. Cooke eds. 1961).

166. See, e.g., T. Jefferson, supra note 165 , at 120 , quoted at text accompanying infra note 280; see also The Federalist No. 47, supra note 4, at $334-47$ (J. Madison).

167. See M. Vile, supra note 101 , at 143-44; G. Wood, supra note 156 , at $446-53$. 
participation of all the major orders of society in the task of governing. ${ }^{168}$ King, nobles and common people each are acknowledged and given power in the government sufficient to prevent any one order from imposing on any other. ${ }^{169}$ Like separation of powers, the theory of mixed government attempts, through structural devices, to render government power safe. However, where the "pure" theory of separation of powers seeks safety by parceling out government functions to different hands, mixed government would avoid tyranny by ensuring that different hands are jointly responsible for the performance of key functions. ${ }^{170}$ When authority must be shared, power can counterbalance power. At the time of the Revolution, this message of mixed government was rejected by most Americans, for the theory reflected a three-tiered social order that had become antithetical to a people who perceived themselves in the throes of establishing a democracy.171 However, the generally acknowledged failure of the early, divisionist state constitutions led influential political thinkers to reassess what the old theory of mixed government could offer the new country. ${ }^{172}$

They were aided in this reassessment by the observation that, despite Montesquieu's strong rhetoric of segregating the "powers" of government, his "ideal constitution" contained significant instances in which the potentially abusive power of government was to be restrained by the sharing, rather than the division, of authority. His legislature could impeach executive ministers and mitigate judicially imposed sentences. ${ }^{173}$ His executive could assemble and adjourn the legislature ${ }^{174}$ and veto its enactments. ${ }^{175}$ Indeed, Montesquieu had gone so

168. See generally G. Wood, supra note 156 , at 197 ("The theory of mixed government was as old as the Greeks and had dominated Western political thinking for centuries."); see also $M$. Vile, supra note 101, at 33-35 (discussing content and evolution of mixed government).

169. The participation of the three orders of society reflects the three classic governmental forms: monarchy, aristocracy and democracy. G. Wood, supra note 156, at 197-99. Each order embodies a distinct political virtue: leadership in the one, wisdom in the few, and common sense in the many. See Michelman, The Supreme Court, 1985 Term-Foreword: Traces of Self-Government, 100 Harv. L. Rev. 4, 44 (1986).

170. M. Vile, supra note 101 , at 33 .

171. Id. at $125-41,148$.

172. Id. at 141-52. John Adams vigorously advocated the virtues of mixed government; however, he was regarded as too sympathetic to monarchy and aristocracy for his theories on governmental structure to provide an acceptable theoretical synthesis of separation of powers and mixed goverument for the mainstream of American political thought. See M. Vile, supra note 101, at 148-49; G. Wood, supra note 156, at 567-69, 577-83.

173. Montesquieu, supra note 157 , bk. XI, ch. 6, at 171. In each instance, Montesquieu was careful to explain why he regarded the legislature's exercise of judicial power as justified by "the particular interest of the party accused." Id. at 170.

174. Id. at 169.

175. Id. at 171. In each instance, Montesquieu emphasized the need to forestall "encroachments of the legislative body." Id. at 169. He was equally insistent, however, that the preservation of liberty required that the executive not "have a part in the legis- 
far as to say that, in order to create a "moderate government, it is necessary to combine the several powers; to regulate, temper, and set them in motion; to give, as it were, ballast to one, in order to enable it to counterpoise the other."176 Thus, one of the most influential proponents of separation of powers did not require an absolute division of governmental functions, but instead tempered the "pure" theory with notions of sharing and balancing drawn from mixed government. ${ }^{177}$

Montesquieu's formulation, however, still reflected the Old World social structure; in his ideal constitution, the tension that afforded control arose from forcing King, aristocrats and common people to wield power jointly. The radical accomplishment of American political theorists in the decade following independence was to cut loose the idea of shared, counterbalancing power from the class-based moorings of mixed government, so that it could become the positive mechanism of restraint which the "pure" theory of separation of powers had lacked. ${ }^{178}$ The result was a transmutation of separation of powers theory. In a document that provided the basis for the influential Massachusetts Constitution of 1780, Theophilus Parsons expounded this new conception: "Each branch is to be independent, and further,

lature by the power of resolving" or take part in "the public debates" leading to the passage of legislation, and he termed it "unnecessary" that the executive have the power to propose legislation. Id. at $171-72$.

176. Id. bk. V, ch.14, at 67-68. He went on ruefully to observe: "This is a masterpiece of legislation, rarely produced by hazard, and seldom attained by prudence." Id. at 68 . The broad distinction between "moderate" and "immoderate" forms of government cut across Montesquieu's classification of the types of political systems. Montesquieu Compendium, supra note 156, at 59; M. Vile, supra note 101, at 81 .

177. In this, Montesquieu reflected the fact that, by the time of the American Revolution, English political theory had amalgamated separation of powers and mixed government into a hybrid, the "balanced constitution." The legislative function would be shared among King, aristocracy and commons so that each social order would have power to counterbalance the others, while the executive and judicial functions would be separated from the legislative. See M. Vile, supra note 101, at 53-54; G. Wood, supra note 156, at 18-20; Montesquieu Compendium, supra note 156, at 77-78.

178. This theoretical revolution, which centered primarily on bicameralism, is traced in detail in G. Wood, supra note 156, at 206-55, 553-62; see also M. Vile, supra note 101, at 143-54. Sketched very briefly, it began with the idea, articulated most forcefully by Theophilus Parsons, that the American "aristocracy" was a meritocracy rather than a hereditary group. In an important commentary on the Massachusetts Constitution of 1780, Parsons identified three qualities as necessary to effective government: concern for the whole, wisdom and dispatch. The first, he theorized, would be found in the lower house of the legislature, the second in the upper aristocratic house, and the third in the chief executive. The elite who comprised the upper house, however, would be defined not by birth, but by education and social and economic success. Thus, a critical element of mixed government-a legislature with an upper (aristocratic) and lower (popular) house-became clothed with a generally acceptable justification. As the 1780 s progressed, the justification for bicameralism evolved. The upper house of the legislature began to be defended not as the embodiment of a special social or intellectual group with a distinct agenda or "voice," but rather as a pure power-checking device, a structural disincentive to hasty, impetuous action and power grabbing. 
to be so balanced, and be able to exert such checks upon the others, as will preserve it from a dependance on, or a union with them."179 James Madison urged the delegates assembled in Philadelphia in 1787 to venture beyond the merely negative device of dividing power and craft a power structure that positively sought balance:

If a Constitutional discrimination of the departments on paper were a sufficient security to each [against] encroachments of the others, all further provisions would indeed be superfluous. But experience had taught us a distrust of that security; and that it is necessary to introduce such a balance of powers and interests, as will guarantee the provisions on paper. ${ }^{180}$

"Balance of powers" thus lost its original meaning as a metaphor for the harmonious participation in government of the natural orders of society, and became instead the watchword for a system of interrelationships through which political power would be diffused and checked. ${ }^{181}$

The new structural conception prevailed at the Convention. However, the idea of separation of powers was so central to the contemporary vision of trustworthy government that Madison then had to answer charges that the new Constitution, by often permitting one branch to exercise a type of power not "rightfully" its own, had disregarded "this essential precaution in favor of liberty." 182 In Federalist 47, he dealt with precedent, arguing that Montesquieu had not demanded absolute partitioning of power and attempting to show that even the early state constitutions had not been entirely divisionist. ${ }^{183}$ But his most effective response came in Federalists 48 and 51 , in which he developed the affirmative case for a structure in which power was shared to accomplish balance. ${ }^{184}$ "To what expedient," he asked, "shall we finally resort for

179. Quoted in M. Vile, supra note 101 , at 151 . Jefferson, commenting during the same period on the defects of Virginia's government structure, was expressing the same conviction that "the powers of government should be so divided and balanced among several bodies of magistracy, as that no one could transcend their legal limits, without being effectually checked and restrained by the others." $T$. Jefferson, supra note 165 , at 120.

180. 2 The Records of the Federal Convention of 1787, at 77 (M. Farrand ed.). Professor Vile suggests that Madison was articulating a view already shared by many of the delegates. M. Vile, supra note 101, at 153 .

181. As Gordon Wood has explained, this new, uniquely American way of looking at politics no longer viewed society as comprising discrete elements embodied in distinct parts of government, but rather as consisting of individuals who exist outside of goverument and collectively choose to distribute power to a number of government organs so that they might achieve the benefits of government and yet be safeguarded from a dangerous accumulation of power. G. Wood, supra note 156, at 590.

182. The Federalist No. 47 , supra note 156 , at 323 . For an account of how the Anti-federalists came to rally round this line of attack on the new Constitution, see $G$. Wood, supra note 156 , at $547-49$.

183. The Federalist No. 47 , supra note 156 , at $324-31$.

184. Federalists 49 and 50 explore and reject two other possible mechanisms for policing the division of power: periodic constitutional conventions, The Federalist No. 
maintaining in practice the necessary partition of power among the several departments ... ?"185 The "only answer," he responded, is "by so contriving the interior structure of the government, as that its several constituent parts may, by their mutual relations, be the means of keeping each other in their proper places." 186 As Madison spun out the new theory, the sharing of power among the branches became not a perversion of the principle of separation of powers, a regrettable concession to the demands of reality, but rather the means most likely to ensure its fullest expression:

[U]nless these departments be so far connected and blended, as to give to each a constitutional controul over the others, the degree of separation which the maxim requires as essential to a free government, can never in practice, be duly maintained. ${ }^{187}$

[T]he great security against a gradual concentration of the several powers in the same department, consists in giving to those who administer each department, the necessary constitutional means, and personal motives, to resist encroachments of the others. ${ }^{188}$

Madison may have been the most important expositor of the Constitution's conception of separation of powers, ${ }^{189}$ but his was not the only voice. James Wilson, influential delegate from Pennsylvania ${ }^{190}$ and eventual Supreme Court Justice, tended to emphasize division of powers to a greater degree than did Madison. ${ }^{191}$ Nevertheless, Wilson eloquently described the importance of shared, counterbalancing power to the new government's structural theory. The three "great powers of government," Wilson emphasized, "should be independent as well as distinct"; yet between them "there ought to be a mutual dependency":

The salutary consequence of the mutual dependency of the great powers of government is, that if one part should, at any time, usurp more power than the constitution gives, or make an improper use of its constitutional power, one or both

49, at 339 (J. Madison) (J. Cooke ed. 1961), and review boards such as committees of censors, The Federalist No. 50, at 344 (J. Madison) (J. Cooke ed. 1961).

185. The Federalist No. 51, at 347 (J. Madison) (J. Cooke ed. 1961).

186. Id. at $347-48$.

187. The Federalist No. 48 , supra note 157 , at 332 .

188. The Federalist No. 51, supra note 185 , at 349 .

189. Freedman, supra note 59, at 1046.

190. Max Farrand names Wilson, Madison, and Washington as the persons most influential in forming and recommending the Constitution. M. Farrand, The Framing of the Constitution of the United States 196-98 (1913).

191. See Sharp, supra note 156, at 407-12, 431. Professor Vile suggests that Wilson, more so than any of the other Framers, tended towards the Continental interpretation of Montesquieu, which emphasized the "pure" separation aspects of his work. M. Vile, supra note 101 , at $85-86,105$. 
of the other parts may correct the abuse, or may check the usurpation.

The important conclusion to be drawn from the premises, which we have established, is, that, in government, the perfection of the whole depends on the balance of the parts, and the balance of the parts consists in the independent exercise of their separate powers, and, when their powers are separately exercised, then in their mutual influence and operation on one another. Each part acts and is acted upon, supports and is supported, regulates and is regulated by the rest. ${ }^{192}$

Likewise, Alexander Hamilton, speaking to the New York ratification convention, ardently advocated a structure in which governmental power was not merely divided but rather apportioned among several power centers in the manner of a system of weights and counterweights:

Sir, when you have divided and nicely balanced the departments of government; when you have strongly connected the. virtue of your rulers with their interest; when, in short, you have rendered your system as perfect as human forms can be,-you must place confidence; you must give power.

The true principle of government is this-make the system complete in its structure, give a perfect proportion and balance to its parts, and the powers you give it will never affect your security. ${ }^{193}$

Thus, our tendency to describe the constitutional scheme as one of "separation of powers and checks and balances" can be misleading. This conventional, bifurcated phrasing obscures the fact that the latter represented, for those who drafted and defended the Constitution, a vital and indispensable aspect of the former. ${ }^{194}$ By the time of the ratification, the prevailing understanding of separation of powers was no longer a simplistic call for absolute segregation of conceptually distinct functions. The experience between independence and the Constitutional Convention had caused American political theorists to rethink the nature of governmental authority. They came to conclude that political power was, in Gordon Wood's words, "essentially homogenous."195 Whether manifested as lawmaking, execution or adjudication, whether exercised by officials who were elected popularly, elected indirectly or appointed, all power in government shared the same fun-

192. Quoted in Sharp, supra note 156, at 414-15 n.59.

193. 2 The Debates in the Several State Conventions on the Adoption of the Federal Constitution 347-48, 350 (J. Elliot ed. 1866).

194. See Freedman, supra note 59, at 1047 (checks and balances was the system "upon which the Constitution was made to rest"); Strauss, supra note 59, at 617 (checks and balances is "at the heart of the framers' formula").

195. G. Wood, supra note 156 , at 604 . 
damental quality: it was dangerous unless adequately offset and controlled. ${ }^{196}$ And so, notwithstanding their literal sense, the words "separation of powers" came to connote something far more subtle and intricate than a mere, abstractly logical division. The phrase expressed the expectation that, through the carefully orchestrated disposition and sharing of authority, restraint would be found in power counterbalancing power.

This complexity of American separation of powers theory is critical to evaluating the history of nondelegation analysis. As the Court, in its century-long process of rationalizing the growth of agencies with the Constitution, gradually shifted its emphasis from safeguarding a particular division of powers to seeking the effective control of power, it was in effect retracing the path of American political thinkers from 1776 to 1787. Those who forged the structural theory of the Constitution did not, of course, foresee the modern administrative agency-with its potent concentration of lawmaking, law-executing and adjudicating power-any more than they anticipated the federal commitment to social and economic intervention that created it. ${ }^{197}$ They were, however, acutely self-conscious that they were designing a plan for the future. ${ }^{198}$ Montesquieu had both reminded them of the inevitability of change and encouraged them to believe that a government designed on separation of powers principles could adapt: "These three powers should naturally form a state of repose or inaction. But as there is a necessity for movement in the course of human affairs, they are forced to move, but still in concert." 199 The peculiarly American conception of separation of powers that they developed sought balance, not stasis. ${ }^{200}$ The

196. Id. at 453; see also id. at 549 (noting how the Federalists' unified conception of the nature of government power shaped their response to the Anti-federalist attack on the Constitution).

197. While the drafters recognized the necessity of an administrative sector of government, their expectation likely extended no further than to "a handful of cabinet departments to conduct the scanty business of government." Strauss, supra note 59, at 582. But cf. G. Wood, supra note 156, at 63-64 (describing the "extensive mercantilist regulation of the economy," including the control of wages and prices and attacks on monopoly, conducted by the Continental Congress, states, counties and towns during the Revolutionary period).

198. See G. Wood, supra note 156, at 3-10, 36-37, 127-29.

199. Montesquieu, supra note 157 , bk. XI, ch. 6 , at 172 ; see also G. Wood, supra note 156, at 29-34 (suggesting that English colonists who became American Whigs tended to see societies as organic and developmental). The three powers to which Montesquieu refers in the quoted section are the two houses of the legislature and the executive. Although he departed siguificantly from earlier political tbinkers by presenting the judiciary as a separate part of government, he did not give it equal status with the legislature and executive; the importance of a professional, independent and active judiciary to a political structure designed to secure liberty was predominantly Blackstone's contribution to American theory. See M. Vile, supra note 101, at 88-90, 104-05.

200. Gordon Wood has described the constitutional combination of separation of powers and federalism as manifesting "a kinetic theory of politics." G. Wood, supra note 156, at 605. Indeed, as Professor Wood has observed, one of the most salient 
genius of a system in which authority was shared rather than rigidly divided was, Madison explained, that each part could respond to the movement of power over time. ${ }^{201}$ Change would simply prompt a readjustment, so long as each part retained "the necessary constitutional means . . . to resist encroachments of the others."202

We can thus understand the structural model as one of dynamic equilibrium: as power flows among the power centers in government, new patterns of counterbalance emerge to provide restraint. The movement of power can be accepted so long as equilibrium can then be reestablished. The model is inherently flexible; new configurations of power may be formed. But its pliancy is not to be mistaken for unconditional license. Innovation in one area may call for a responsive shift in other areas. An exercise of authority by one branch may become constitutionally necessary because of a realignment of power elsewhere in government.

The development of the administrative state strained the limits of even this most flexible model's capacity to accommodate change. By funneling enormous power into agencies, the regulatory statutes enacted in this century have radically reconfigured the pattern of government authority. As the Court's nondelegation analysis ultimately apprehended, this development can be reconciled with separation of powers principles if, but only if, the new concentration of power is offset by correlative checks. And, as Judge Leventhal recognized, the interpretive authority is one critical dimension along which such a check can be interposed. ${ }^{203}$ Given the many factors that cause legislatures to fail to speak clearly and precisely in regulatory statutes, ${ }^{204}$ the quantum of power represented by the responsibility to resolve statutory ambigu-

characteristics of American political theory in the period was that it was "continually adapting and adjusting to ever-shifting political and social circumstances." Id. at 438.

20I. The Federalist No. 51 , supra note 185 , at 349 , quoted supra text accompanying note 188 .

202. Id.

203. I do not mean to suggest that statutory interpretation is the only, or even the most important, area in which counterbalance to the mass of administrative power can or should be supplied. Just as agency discretion has a variety of aspects, see infra note 2I8, so control must be multidimensional. See, e.g., DeLong, supra note 28 , at 400 , 405-1 1; Strauss, supra note 59. Still, that control will have to be achieved incrementally, and interpretation is not only a significant occasion for providing counterbalance but also one that is more congenial than many others to judicial management.

204. The public choice theorist's explanation has already been noted. See supra note 43. But public choice theory can overstate the dark side of statutory ambignity. Congress often produces legislation of staggering obscurity on "issues that have little or no political significance in the partisan sense." The Intercircuit Panel Act: Hearings on S. 704 Before the Subomm. on Courts of the Senate Comm. on the Judiciary, 99th Cong., Ist Sess. 36 (1985) (letter from Hon. John Paul Stevens). Ambiguity is as often a product of what Richard Epstein has called "misplaced virtue" (good intentions poorly executed), "vanity" (everyone wanting to include some sign of her own handiwork), time constraints and lack of information as it is of self-serving obfuscation. See Epstein, supra note 61 , at 103 . 
ity is not insignificant. ${ }^{205}$ The choice between deference and independent judgment is, at bottom, a choice between whether this authority will further swell agency power or will instead help to counterbalance it. Whether or not there existed some original constitutional mandate that the judiciary hold the interpretive authority, separation of powers may require that, in the twentieth century administrative state, the choice be made in favor of counterbalance. ${ }^{206}$

Thus, Cheoron's assumption that deference is necessary to avoid judicial usurpation of power Congress wished to place elsewhere fundamentally misperceives the separation of powers implications of the choice of interpretive model. Both the doctrinal pedigree of administrative agencies provided by the line of nondelegation cases, and the intellectual history of separation of powers which validates the path those cases took, argne that much more is at stake than simply discerning and respecting the will of a coordinate branch. If Congress chooses to delegate regulatory authority to agencies, part of the price of delegation may be that the court, not the agency, must hold the power to say what the statute means. In other words, Cass Sunstein's pithy criticism of deference according to Cheoron- "foxes shouldn't guard henhouses"207 - is a counsel not merely of prudence, but of constitutional necessity.

It might be objected, however, that one can accept the proposition that the flow of power to agencies must be offset by some correlative counterweight without concluding that the judiciary be the branch providing the necessary external control. And this objection might be supported (although the Court did not attempt any such connection) by invoking Chevron's second constitutionally based justification for choosing deference. The "interference with legitimate political control" ar-

205. And, as noted earlier, Chevron and Young's extravagant conception of when a statute is ambiguous greatly expands the power at stake in allocating the interpretive authority. See supra notes 52-53 and accompanying text.

206. To suggest that independent judgment may have become constitutionally imperative implies that judicial review of agency action will be available in the first place. Inasmuch as Congress routinely provides for review, see supra note 81 and accompanying text, this will rarely cause practical difficulty. From a theoretical standpoint, the matter is more complicated. Whether there is a constitutional right of judicial review or, put differently, whether Congress has the constitutional power to preclude review (directly or indirectly through the withdrawal of jurisdiction) is a complex question that has generated an impressive body of commentary and defied any satisfying resolution. In addition to Henry Hart's legendary Dialogue, supra note 2, see the sources collected in Hart and Wechsler's The Federal Courts and the Federal System 379-87 (3d ed. 1988), and in P. Low \& J. Jeffries, Federal Courts and the Law of Federal-State Relations 166-67 (1987); see also S. Breyer \& R. Stewart, supra note 57, at 1074-78. The question has not generally been approached from the perspective of the separation of powers argument developed in the text, although the argument logically encompasses the necessity of judicial review per se. For an effort along these lines, see Note, Congressional Preclusion of Judicial Review of Federal Benefit Disbursement: Reasserting Separation of Powers, 97 Harv. L. Rev. 778 (1984).

207. Panel Discussion, supra note 12 , at 368 . 
gument asserts that courts, as the branch least accountable to the people, are the branch least suitable to make the policy choices inherent in interpreting regulatory statutes. ${ }^{208}$ It argues that the deferential model is constitutionally preferred because it permits agencies to make those choices under the supervision and control of the political branches. The assumptions underlying this second justification for deference must next be examined.

\section{INDEPENDENT JUdGMENT AS INTERFERING WITH Legitimate Political ConTrol?}

Cheuron's depiction of deference as a necessary judicial affirmation of democratic decision making strikes a deep constitutional chord. After observing that "[j]udges are not experts in the field, and are not part of either political branch of the Government,"209 the Court writes:

When a challenge to an agency construction of a statutory provision, fairly conceptualized, really centers on the wisdom of the agency's policy, rather than whether it is a reasonable choice within a gap left open by Congress, the challenge must fail. In such a case, federal judges-who have no constituency-have a duty to respect the legitimate policy choices made by those who do. The responsibilities for assessing the wisdom of such policy choices and resolving the strnggle between competing views of the public interest are not judicial ones: "Our Constitution vests such responsibilities in the political branches."210

The reasoning is adroit. Construing ambiguous regulatory statutes is really just a species of policy making. Policy making is the province of the elected branches, not the judiciary. Therefore, the constitutionally appropriate interpretive model is one that turns the problem of statutory meaning over to the political process and confines the role of unelected judges to asking merely whether the interpretation/policy choice that emerges is a "reasonable" one. Deference thus becomes a way to assuage another of the prime constitutional anxieties bred by broadly delegative statutes: the fear that the power to define public policy is passing out of the hands of the people's elected representatives.

Appealing as it seems, this "interference with legitimate political control" justification for deference can nonetheless be challenged on many levels. In the first place, treating the interpretation of regulatory statutes as simply an exercise in policy making has troubling implications, some of which have already been noted. ${ }^{211}$ In particular, when this view of interpretation is superimposed on Chevron's rule that a stat-

208. See supra notes $61-62$ and accompanying text.

209. Cheuron, 467 U.S. at 866.

210. Id. (quoting TVA v. Hill, 437 U.S. 153, 195 (1978)).

211. See supra text accompanying notes 101-02. 
ute is "ambiguous" (and hence fair game for "interpretation") whenever it does not provide unequivocal direction on the precise point at issue, great potential is created for overlooking substantive directions and limitations that the enactors had intended, and attempted, to incorporate in the statute. ${ }^{212}$ Even in the unlikely event that the "meaning" selected by the agency accurately reflects the wishes of the people's current elected representatives, ${ }^{213}$ the prospect that regulatory statutes will routinely be amended or even repealed by "interpretation" should at least give us pause. In the second place, the Court's reasoning reflects a singularly narrow conception of the judicial function. Cheoron implies that the shaping of public policy is so foreigu to the judiciary's proper task that courts must avoid responsibility for resolving policy questions whenever possible. ${ }^{214}$ The primacy of the political branches in establishing domestic and foreign policy is beyond dispute; surely, however, it overstates theory and distorts reality to suggest that the judicial role in defining public policy is an extraordinary one, legitimately undertaken only as a last resort. Far-reaching policy resolutions are a

212. An interpretative model that fails accurately to discover and enforce such directions and limitations actually creates legitimacy problems. As Louis Jaffe has observed: "[A] delegation of power implies some limit. Action beyond that limit is not legitimate." L. Jaffe, supra note 2, at 320 ; accord Garland, supra note 26, at 586 (The "central tenet" of the traditional model of administrative law is that "agency action is justifiable only if it remains faithful to the dictates of the legislative process.") (footnote omitted); see also Stewart \& Sunstein, supra note 67 (noting that infidelity to the statutory dictates may take the form of agency failure to act, as well as action that transcends statutory limits). This legitimacy concern might be called "scope-of-authority legitimacy," as distinguished from the sort of legitimacy about which the text is primarily concerned-which refers to the manner in which public policy is formulated in a representative democracy and which might therefore be called "policy-making legitimacy." Ultimately, of course, the two, though distinct, are related, for the insistence that delegees of power abide by the instructions of the delegation is generated by the recognition that those instructions are themselves a policy choice made by the peoples' representatives through the full legislative process. See, e.g., Mikva, supra note 21 , at 3 ("U]udicial review for fidelity to the agency's statute is the primary means for a democracy to ensure that the agencies are carrying out the will of the politically accountable branches of government."). Because of this relationship, an interpretive model that creates scope-of-authority legitimacy problems in the ostensible pursuit of policy-making legitimacy does not represent much of a solution.

213. See Diver, supra note 2 , at 581-82 (discussing theories that agency interpretation may pursue self-interested objectives rather than serving wishes of current legislature); Stewart, supra note 59, at 1684-86, 1713 (reviewing basis of various theories of systematic bias in agency policy); see also Sargentich, supra note 59, at 428-29 (discussing effect of bureaucratic structure on agency policy making).

214. This aversion to judicial policy making can also be seen in the portion of the opinion quoted infra text accompanying note 251 . See generally Note, supra note 52 , at 902 (discerning a trend in which "the Court has come to lament its own incompetence with increasing frequency") (footnote omitted); cf. Strauss, supra note 21, at 1095, 1117-35 (suggesting that workload constraints on Court's ability to supervise lower courts have led to doctrinal developments, including Cheuron, consciously designed to curtail judicial discretion). 
regular part of both common-law and constitutional adjudication. ${ }^{215}$ Even if common-law examples are dismissed as irrelevant to the federal courts and constitutional adjudication is distinguished as sui generis, the federal judiciary has long administered sweeping yet open-textured statutes in such areas as antitrust, labor and civil rights. ${ }^{216}$ Whatever one's views of the wisdom of this, it simply cannot be considered aberrant for federal courts to resolve policy questions as part of deciding cases properly before them.

Even if we were to accept that interpretation is merely policy making and that public policy can legitimately be shaped only by the political branches, the most fundamental problems with Chevron's second justification for deference remain. The proposition that deference is constitutionally compelled in order to legitimate regulatory policy making rests on two assumptions. First, if courts follow the deferential model, agencies will exercise the interpretive power subject to the direction of the political branches; second, the direction agencies receive will indeed respond to the constitutional concerns raised by the delegation of regulatory power. Once again, neither of these critical assumptions is self-evidently correct, and neither is scrutinized by the Court. In fact, the first assumption may be wholly unfounded and certainly is misleading to the extent it implies that Congress will regularly play an active directory role in agencies' interpretive decisions. And since the President is the "political branch" most likely to achieve control over

215. The rejection of privity as a defense to defective products claims, see MacPherson v. Buick Motor Co., 217 N.Y. 382, 111 N.E. 1050 (1916), is the classic common-law example, although the growing perception that the common law itself represents a system of regulation, see, e.g., R. Posner, Economic Analysis of Law 229-33 (3d ed. 1986), would suggest that the judiciary's role as shaper of public policy has been far broader than a focus on only individual (though undoubtedly spectacular) events like MacPherson might imply.

In the constitutional area, one's immediate reaction may be to associate significant judicial policy shaping with cases decided in the last 35 years. However, such early cases as Gibbons v. Ogden, 22 U.S. (9 Wheat.) 1 (1824); Trustees of Dartmouth College v. Woodward, 17 U.S. (4 Wheat.) 518 (1819); and McCulloch v. Maryland, 17 U.S. (4 Wheat.) 316 (1819), can readily take their place beside Brown v. Board of Educ., 349 U.S. 294 (1955) and Roe v. Wade, 410 U.S. 113 (1973), as sigual instances of far-reaching policy resolutions. On the impact of Gibbons, see 2 Encyclopedia of the American Constitution 841-43 (L. Levy, K. Karst \& D. Mahoney eds. 1986); on Dartmouth College, see id. at 537-39; and on McCulloch, see 3 id. at 1234-37. See generally $1 \mathrm{C}$. Warren, The Supreme Court in United States History 19 (1922) (Through these three and other early cases, "the Court has largely controlled and directed the course of the economic and social development of the United States.").

216. These statutes are largely the product of this century. See examples given supra note 77. But see the remnants of the Civil Rights Acts of 1866 and 1871 codified at 42 U.S.C. $\S \S 1981-1983,1985$ (c) (1982). However, prior to the 1938 watershed decision in Erie R.R. v. Tompkins, 304 U.S. 64 (1938), the federal courts would have had less hesitancy in identifying themselves with the common-law tradition. See generally 2 Encyclopedia of the American Constitution, supra note 215, at 689-91 (discussing federal common law before and after Erie). 
such decisions, the second assumption is also inaccurate-at least in view of how principles of legitimacy and separation of powers traditionally have been framed.

\section{A. Congress, the President, and Control of Agency Discretion}

As previously noted, ${ }^{217}$ Chevron's deferential model openly converts statutory interpretation into an aspect of policy making. Once ambiguity is discerned, the model accepts the existence of a set of "rational" versions of the statute's "meaning," any one of which the court will, at the agency's behest, sustain. Chevron empowers-indeed invites-the agency to select, from within that set of meanings, the one most congenial to its current regulatory philosophy and objectives. Hence, the question of who will control agencies' exercise of the interpretive power is comprised in the larger question of who controls administrative policy-making discretion. ${ }^{218}$

Many observers of the growth of the administrative state would respond that administrative discretion is rarely directed, on a consistent or sustained basis, by any person or institution outside the agency. The fear that agencies-particularly the independent agencies-have moved beyond the effective control of the political branches was voiced at the height of the New Deal, ${ }^{219}$ and continues to be expressed, in varying degrees of intensity, by judges, academics, practitioners and politi-

217. See supra notes $61-63,98-102$ and accompanying text.

218. The discussion that follows is subject to two caveats: First, while the interpretive power given agencies under the deferential model becomes part of administrative policy-making discretion, it by no means constitutes all, or even a major part of, that discretion. Making policy choices within established statutory bounds through rule making or adjudication, applying existing policy to different factual situations, setting policy through enforcement (both in decisions whether to initiate enforcement proceedings and in assignment of penalties/remedies), and framing and responding to legislative proposals (substantive and budgetary) are all additional aspects of administrative policymaking discretion. See generally Koch, lssues in Administrative Law-Judicial Review of Administrative Discretion, 54 Geo. Wash. L. Rev. 469 (1986) (proposing a system for classifying the varieties of agency discretion).

Second, the discussion generalizes across agencies. Some commentators would condemn this methodology as impossibly inaccurate. See, e.g., Delong, supra note 28 (arguing that control varies according to a wide variety of factors including size, organizational structure and status as a traditional regulatory agency versus a newer, social regulatory agency). Others are more willing to make broad assessments about the relative ability of Congress and the President to direct the administrative process. E.g., Bruff, supra note 59, at 229-36; Strauss, supra note 59, at 592-96. For present purposes, it is enough to note that deference under Cheoron is not agency-specific. See, e.g., NLRB v. United Food and Commercial Workers Union Local 23, 108 S. Ct. 413, 421 (1987) (applying Chevron, without distinction, to an independent agency). The assumptions that underlie Chevron's choice of interpretive model can therefore be examined on their own terms by treating agencies in the aggregate.

219. See supra note 84 (quoting The President's Committee on Administrative Management). 
cians. ${ }^{220}$ It reflects the very plausible skepticism that either Congress or the President can penetrate the immense size and bewildering complexity of the federal bureaucracy to reach the decision makers who matter or overcome the volume and technical complexity of regulations to affect their content to any significant extent.221 If this fear is wellfounded, then Chevron's "interference with legitimate political control" argument founders on the facts at the very outset. For the deferential model to result in interpretive choices being made under the direction of elected officials, Congress and/or the President must exert meaningful direction over agency decisions. Put somewhat differently, the independent judgment model cannot supplant political control that does not exist.

Other observers believe, however, that the "headless fourth branch" metaphor overstates the autonomy of agencies. They note that administrative decision makers are often keenly aware of and responsive to their political environment.222 But the fact that agencies may keep an attentive ear on emanations from Capitol Hill and the White House does not mean that Congress and the President compete on an equal footing in the struggle to influence administrative discretion. Rather, a potent combination of constitutionally granted powers, congressional acquiescence (taking the form of both custom and statute) and institutional and organizational factors have contributed to the emergence of the President as the dominant force in regulatory policy making. ${ }^{223}$ A few examples of this synergy can demonstrate the point

220. See, e.g., ABA Comm'n on Law and the Economy, Federal Regulation: Roads to Reform 73 (1979); R. Litan \& W. Nordhaus, supra note 57, at 60-81; Bruff, Presidential Power and Administrative Rulemaking, 88 Yale L.J. 451, 456-57, 459, 469 (1979); McGowan, supra note 1, at 223-26; Sunstein, supra note 99, at 57 .

221. By any measure, the regulatory enterprise is a behemoth. The 60,000 -odd annual pages of the Federal Register dwarf Congress's annual production in the Statutes at Large. The approximately 200,000 cases handled annually by the federal courts pale beside the tens of millions of claims disposed of each year by the Social Security Administration and the IRS; even agencies with a more specialized client base annually process far more filings than the federal courts. See S. Breyer \& R. Stewart, supra note 57, at 2 (noting that the Interstate Commerce Commission handled more than 350,000 filings in 1976). A single industry, the steel industry, is subject to over 5,000 regulations administered by 25 federal agencies. R. Litan \& W. Nordhaus, supra note 57 , at 48 . The dollar volume of the costs and benefits produced by federal regulation has been estimated at $\$ 50$ billion annually, id. at 8 , of which more than $\$ 3$ billion, id. at 19 , is the direct cost of running the over 80 agencies, id. at 46 , that employ almost 3 million people. P. Shane \& H. Bruff, The Law of Presidential Power 270-71 (1988).

222. See, e.g., Strauss, supra note 59, at 583-96; Woodward \& Levin, supra note 10 , at 340 ; see also Bruff, supra note 59 , at $228-44$ (discussing variety of ways in which "the three constitutional branches and numerous interest groups confer rewards and exact penalties" for agency policy choices).

223. Some commentators would go even further and credit the President with having become the dominant force in public policy making as a whole. See, e.g., C. Rossiter, The American Presidency 26-28 (2d ed. 1960) (" $[W]$ e may therefore consider [the President] to be the Chief Legislator."); Miller, An Inquiry into the Relevance of the 


\section{without belaboring it.}

The appointment of agency heads illustrates how custom has combined with the Constitution to strengthen the President's hand. Control over the power to appoint key government officials was an issue of intense concern for the Framers. Article II, section 2 of the Constitution, providing for presidential appointment of major officers with Senate consent, represented a deeply considered and much debated attempt to balance executive and legislative involvement in the selection process. ${ }^{224}$ However, although the power to withhold consent could have made the Senate a powerful (if not quite equal) partner with the President in choosing top administrators, the confirmation process has, by custom, rarely interfered with his preferences. ${ }^{225}$ As a consequence, the appointment power has come to represent a significant opportunity for a skillful and determined President to extend his influence by placing in critical agency positions those who share his regulatory philosophy. ${ }^{226}$

Intentions of the Founding Fathers, With Special Emphasis Upon the Doctrine of Separation of Powers, 27 Ark. L. Rev. 583, 591 (1973) ("the President today "wears ten hats-as Head of State, Chief Executive, Minister of Foreign Affairs, Chief Legislator, Head of the Party, Tribune of the People, Ultimate Arbiter of Social Justice, Guardian of Economic Prosperity, and World Leader of Western Civilization" ") (quoting Amaury de Reincourt).

224. On the influence, early in the Confederation period, of the Americans' conviction that misuse of the appointment power had contributed to usurpation of power by the Crown, see supra notes I61-63 and accompanying text. On the evolution of American political thinking on the appointment power, leading to the Federalists' insistence that it was less dangerously lodged in the President than in the Legislature, see M. Vile, supra note 101 , at $142-44,151,156-57$; G. Wood, supra note 156 , at $435,452,551-53$.

225. See R. Litan \& W. Nordhaus, supra note 57, at 62-63; Bruff, supra note 220, at 458. For executive branch agencies, confirmation is typically the only legal hurdle the President must surmount in filling senior positions with the candidates of his choice. For independent agencies, the organic statutes typically impose additional requirements of bipartisan membership and fixed terms. Even here, however, a determined President can exert significant influence. Members of the opposing party sympathetic to the President's regulatory philosophy can often be found. Moreover, the President typically holds the power to name the chair of inclependent agencies, an appointment that continues at the President's pleasure and that can make a considerable difference in channelling the agency into a path consistent with presidential views. See Strauss, supra note 59 , at 590-91 \& nn.66-68.

226. Some observers have noted that presidents do not always use the appointment power effectively. See, e.g., Cutler \& Johnson, supra note 59, at 1410. But see P. Shane \& H. Bruff, supra note 221, at 271 (noting "increasingly close White House control" over appointments). Others observe that appointees sometimes act to appease interest groups or congressional sponsors rather than conforming to the President's views. See, e.g., Bruff, supra note 59, at 234. Still, the Reagan presidency exemplified how powerful a tool for shaping agency policy the appointment power can be in the hands of an ideologically strong and politically savvy president.

Of course, even a new appointee thoroughly dedicated to the Presiclent's policy agenda must deal with an entrenched staff, most of whom are civil service appointees. But cf. P. Shane \& H. Bruff, supra note 221, at 269 (noting increase, in recent decades, of the proportion of political appointees). Even here, however, the President can exer- 
The way in which the President's constitutional powers have been enhanced by Congress's statutory cooperation and subsequent acquiescence is exemplified by the evolution of the Office of Management and Budget (OMB). Created by statute in 1921 as the accountant for the executive branch, ${ }^{227}$ the OMB underwent a dramatic reorganization in $1970 .{ }^{228}$ It emerged with significant managerial functions that have enabled it to become a powerful device for imposing the President's stamp on the regulatory process. ${ }^{229}$ Possessing almost mythic stature as "the Cerberus at the gate of any program" an agency proposes to undertake or strengthen, the OMB now serves as a filter between agencies and Congress. ${ }^{230}$ Except for certain agencies that have been statutorily exempted from the requirement, agencies must obtain $\mathrm{OMB}$

cise a degree of influence. The Office of Personnel Management (successor to the Civil Service Commission) obtains clearance from the White House before making appointments to senior staff positions in executive branch agencies. Freedman, supra note 59, at 1062 n.101; Strauss, supra note 59, at 589. In the independent agencies, the chair (who generally owes his or her position to the President, see supra note 225) selects most staff and sets budgetary policy powers that tend to command staff loyalties. Strauss, supra note 59, at 591. See generally P. Shane \& H. Bruff, supra note 221 , at 271 (noting Reagan Administration's aggressiveness in this area).

The other major aspect of directing agency policy making through control over key personnel is removal. In this area, the respective roles of Congress and the President are less well-settled, but it is apparent that the latter comes out significantly ahead. The power to remove top administrators of agencies within the executive branch appears to lie, as a constitutional matter, within the President's sole control, see Myers v. United States, 272 U.S. 52, 161 (1926), although there may be political constraints on making controversial moves. See Strauss, supra note 59, at 590. As for heads of independent agencies, Congress apparently may control removal to the extent of imposing a statutory "for cause" requirement, see Wiener v. United States, 357 U.S. 349, 352, 356 (1958); Humphrey's Executor v. United States, 295 U.S. 602, 629 (1935), but may not participate directly in determining whether "cause" is present. See Bowsher v. Synar, 478 U.S. 714 (1986). That power, it seems, must be exercised solely by the President. Id. The critical question-whether "cause" can include the President's view that the administrator's discretion has not been exercised wisely-is still open.

227. Budget and Accounting Act, 1921, ch. 18, tit. 11, $\S 207,42$ Stat. 20, 22 (codified as amended at 31 U.S.C. $§ 501$ (1982)).

228. Reorganization Plan No. 2 of 1970, 84 Stat. 2085 (codified as amended at 31 U.S.C. $\$ 501$ (1982)). On the effectiveness of reorganization plans as a device for enhancing presidential control over substantive regulatory policy, see generally Karl, Executive Reorganization and Presidential Power, 1977 Sup. Ct. Rev. 1.

229. OMB's closeness to the President is formally emphasized by its location, on the organizational chart, within the Executive Office of the President and is captured viscerally by the recent statement of one OMB official: "We are the president, that's what we are." Quoted in M. Benson, Budget Office Power Grows Under Reagan, New Orleans Times-Picayune, Mar. 9, 1986, at A8, col. 1 .

230. W. Cary, Politics and the Regulatory Agencies 12 (1967). Using a different metaphor to capture the same idea, one of the OMB's recent directors described his agency as the "court of last resort" for proposed rules. New Reg Reformer Puts Bureaucrats on Notice, Legal Times of Wash., Mar. 16, 1981, at 8, col. 1 (quoting James Miller, Director, Office of Information and Regulatory Affairs in the OMB). See generally P. Shane \& H. Bruff, supra note 221, at 335-36; Freedman, supra note 59, at $1061 \mathrm{n} .101$. 
clearance of proposals for legislation and even legislative testimony. ${ }^{231}$ In addition, the OMB presses the President's view of the relative priorities to be accorded various regulatory activities through its control over the budget. ${ }^{232}$ Although the coercive potential of budget clearance has been vitiated for some agencies by statutory requirements that their original funding requests be transmitted to Congress, ${ }^{233}$ the overall policy-shaping effect of the OMB's budgetary power is significant. ${ }^{234}$ Perhaps most important, the OMB serves as a powerful conduit for injecting the President's views directly into the rule-making process. This is accomplished in part through the agency's formal responsibility to monitor proposed rules for compliance with applicable Executive Orders. $^{235}$ Additionally, the OMB maintains an active practice of informally communicating the White House position to agency personnel during the rule-making process. ${ }^{236}$ Highly controversial and heavily

231. See P. Shane \& H. Bruff, supra note 221 , at 335 ; Strauss, supra note 59 , at 589-90. The specific agencies that have been statutorily exempted are independent agencies, but no blanket exemption for the independents thus far exists. See id. at 590 \& n.62.

232. P. Shane \& H. Bruff, supra note 221, at 335; Strauss, supra note 59, at $588-89$.

233. Again, these agencies are independent, but not all independent agencies have obtained this sort of protection. See Strauss, supra note 59, at 588-89 \& n.60.

234. P. Shane \& H. Bruff, supra note 221, at 336; Strauss, supra note 59 , at 588-89.

235. See, e.g., Exec. Order No. 12,498, 50 Fed. Reg. 1036 (1985) (creating a "Regulatory Planning Process" in which the OMB polices the requirement that all "regulatory actions" be "consistent with the goals of the agency and of the Administration"). On the OMB's role as policy coordinator, see S. Breyer \& $\mathrm{R}$. Stewart, supra note 57 , at 110-12 \& 1988 Supp. at 12-15; P. Shane \& H. Bruff, supra note 221, at 336.

Recent Presidents, relying on article II, section 3's directive to "take Care that the Laws be faithfully executed," as a source of inherent power to superintend agency performance, have used the executive order as a mechanism for asserting greater control over administrative policy making. See R. Litan \& W. Nordhaus, supra note 57, at 67-81; P. Shane \& H. Bruff, supra note 221, at 343-66. Ronald Reagan's Executive Order 12,29I, 46 Fed. Reg. 13,193 (1981) requiring the use of cost-benefit analysis in formulating rules and legislative proposals, has been the most ambitious in the series of such orders. See Shane, Presidential Regulatory Oversight and the Separation of Powers: The Constitutionality of Executive Order No. 12,291, 23 Ariz. L. Rev. 1235 , 1235-36 (1981). Although that Order (like its predecessors and other Reagan Executive Orders) applied by its terms only to executive branch agencies, the independents generally chose to comply voluntarily. See Strauss, supra note 59, at 592-94. Executive Order No. 12,291, and the OMB's role as its enforcer, have been the subject of intense controversy. See, e.g., Symposium, Cost-Benefit Analysis and Agency Decision-Making: An Analysis of Executive Order I2,291, 23 Ariz. L. Rev. 1195 (1981) [hereinafter Symposium]; see also sources cited infra note 237.

236. See S. Breyer \& R. Stewart, supra note 57, at 655; Note, OMB Intervention in Agency Rulemaking: The Case for Broadened Record Review, 95 Yale L.J. 1789, I800-02 (1986). See generally Verkuil, Jawboning Administrative Agencies: Ex Parte Contacts by the White House, 80 Colum. L. Rev. 943 (1980) (discussing preference of Presidents to "cajole, persuade or arbitrate" rather than participate formally in the rulemaking process). The OMB also "coordinates" the comments of other agencies on proposed rules. Strauss, supra note 59, at 588; see also Bruff, supra note 59, at 233 (arguing that OMB's "centralized review of regulation can help the President check policy 
scrutinized as the OMB has been in the last few years, it has escaped any meaningful legislative curb on its activities. ${ }^{237}$

The often informal but pervasive authority the White House wields over agencies has been captured in Peter Strauss's useful phrase the "directory power."238 This power is the rather amorphous whole that includes the appointment power with the loyalties it generates and the persuasion/coercion of OMB oversight, but that is greater than the sum of its parts. It is, in a sense, the aura of power in reserve. As Professor Strauss puts it: "The White House does not have to be explicit with an agency about results; it has enough power to act much more indirectly." 239

This "power to act" stems not simply from constitutional and statutory grants and congressional acquiescence, but also from the very structure of the presidency. After intense debate about the proper organization of the executive branch, the drafters of the Constitution settled on a unitary President who would be capable of the dispatch, coordination, initiative and consistency necessary to maintain law and order and conduct foreign policy. ${ }^{240}$ Not surprisingly, those deliber-

that may result from agency alliances with congressional committees and interest . groups, enhancing his power against those forces").

237. The OMB's intervention in the regulatory process has been the focus of congressional investigation, e.g., Senate Comm. on Env't \& Pub. Works, Office of Management and Budget Influence on Agency Regulations, S. Rep. No. 156, 99th Cong., 2d Sess. (1986); The Role of OMB in Regulation: Hearing Before the Subcommittee on Oversight and Investigations of the House Comm. on Energy and Commerce, 97th Cong., 1st Sess. (1981), study by management consultants, e.g., National Academy of Pub. Admin., Presidential Management of Rulemaking in Regulatory Agencies (1987), court challenge, e.g., Public Citizen Health Research Group v. Tyson, 796 F.2d 1479, 1483, 1507 (D.C. Cir. 1986); Environmental Defense Fund v. Thomas, 627 F. Supp. 566 (D.D.C. 1986), political commentary, e.g., Sibbison, Whose Agency Is It Anyway?: How OMB Runs EPA, 17 Wash. Monthly, Dec. 1985, at 19, and extensive debate among judges, practitioners and scholars, e.g., Symposium, supra note 235; DeMuth \& Ginsburg, White House Review of Agency Rulemaking, 99 Harv. L. Rev, 1075 (1986); Morrison, OMB Interference with Agency Rulemaking: The Wrong Way to Write a Regulation, 99 Harv. L. Rev. 1059 (1986); Olson, The Quiet Shift of Power: OMB Supervision of EPA Rulemaking under Executive Order 12291, 4 Va. J. Nat. Resource L. 1 (1984); O'Reilly \& Brown, In Search of Excellence: A Prescription for the Future of OMB Oversight of Rules, 39 Admin. L. Rev. 421 (1987); Strauss \& Sunstein, The Role of The President and OMB in Informal Rulemaking, 38 Admin. L. Rev. 181 (1986). One of Congress's few concrete responses to the firestorm surrounding the OMB has been to require Senate confirmation of the appointment of the director of the Office of Information and Regulatory Affairs, the component of the OMB responsible for the executive-order compliance program. See Paperwork Reduction Reauthorization Act of 1986, Pub. L. No. 99-591, §813(a), 100 Stat. 1783 (codified at 44 U.S.C $\S \S 101$, 3501-3507, 3511, 3514, 3520).

238. Strauss, supra note 59 , at $666-67 \&$ n. 402 .

239. Id. at 666-67. The independent agencies' voluntary compliance with executive orders would seem a good illustration of the directory power at work.

240. See The Federalist No. 70 (A. Hamilton) (J. Cooke ed. 1961). As noted earlier, the legislative dominance of the Confederation period had provoked general dissatisfaction, and by the time of the Constitutional Convention the prevailing sentiment 
ately cultivated qualities can prove just as effective when turned to shaping domestic policy. In the struggle to direct administrative discretion, a single, highly visible, constantly present Chief Executive is at a considerable structural advantage when compared with a collegial legislative body that assembles only periodically, must act through a complex set of procedures by consensus of its several hundred members and is vulnerable to substantial turnover in membership every two years.

The practical constraints that flow from the institutional structure of Congress were as deliberately cultivated as the practical advantages that flow from the structure of the presidency. The Framers perceived the lawmaking power as necessarily large and concomitantly dangerous. ${ }^{241}$ Accordingly, they designed the branch which would hold this power in a manner that disabled it from making or changing public policy too quickly or too often.242 What they did not foresee, however, was the movement of vast portions of the lawmaking power from that original, carefully structured repository into another part of government. Now, although Congress possesses two of the most potentially powerful devices for controlling agency behavior-the power of the purse and the power to amend or even repeal the agency's organic statutes-the same cumbersome organization and time-consuming process upon which the Framers relied to constrain the legislative branch in itself establishing or amending policy hinders it from using those devices effectively or extensively to direct the policy making of its delegees. Thus, while the appropriations power is sometimes used to modify agency behavior, congressional control of regulatory policy through the budget tends to be sporadic and very particularized;243

favored a stronger national executive. See supra text accompanying notes 162-66; see also infra text accompanying notes 274-81. There was no easy consensus, however, on precisely how strong the executive should be and how it should be structured. For a succinct description of the debates over the organization of the executive and the scope of its powers, see E. Corwin, The President: Office and Powers 1787-1957, at 10-16 (1957); P. Shane \& H. Bruff, supra note 221, at 8-12. For more extended discussion, see C. Thach, The Creation of the Presidency, 1775-1787, at 76-139 (1923).

241. See infra note 282 and accompanying text.

242. Reflecting the Confederation-period experience with legislating run amok, see supra note 165 and accompanying text, both Madison and Hamilton extolled the virtues of deliberation in lawmaking and stability in the law and took pains to explain how these virtues were cultivated by the structure of the legislative branch. See, e.g., The Federalist No. 62, at 419-22 (J. Madison) (J. Cooke ed. 1961) (discussing how Senate will function to avert "the mischievous effects of a mutable government"); The Federalist No. 70 , supra note 240 , at 475 (A. Hamilton) (contrasting the unitary executive's capacity for dispatch with the multimember legislature, whose "differences of opinion" and "jarring of parties" is not only inevitable but also beneficial, for "[i]n the legislature, promptitude of decision is oftener an evil than a benefit").

243. See Bruff, supra note 220, at 457-58; Kaiser, Congressional Action to Overturn Agency Rules: Alternatives to the "Legislative Veto", 32 Admin. L. Rev. 667, $687-89,710$ (1980). Judge and former Congressman Mikva has suggested that the appropriations power is ultimately too big a gun to be an effective control device: 
although effective in specific instances, it affords no real competition to the comprehensive, sustained policy direction the President can achieve through the OMB. Similarly, the passage of substantive legislation to override or amend agency policy choices does occur, but not very often. ${ }^{244}$ The institutional obstacles to formal congressional response are likely to be overcome only when the agency's position has incited widespread or well-organized discontent, and most agencies are politically adept enough to avoid taking many such extremely provocative actions. ${ }^{245}$

There are, of course, control devices outside the formal legislative process. Oversight hearings by standing or special committees can subject agency personnel to sufficient harassment and embarrassment that the agency comes to heel, at least temporarily. These sorts of exercises are relatively infrequent, ${ }^{246}$ although they can be sufficiently spectacular when they do occur that agencies other than the "victim" are sensitized to messages emanating from Capitol Hill. Agency action can be publicly castigated on the House or Senate floor, and members of Congress or their staffs can importune agency decision makers. ${ }^{247}$ The principal difficulty with these informal control devices, however, is that

"Congress must destroy a regulatory regime to control it. The power of the purse is a very blunt tool at best. It can halt agency action, but only at a high price." Mikva, The Changing Role of Judicial Review, 38 Admin. L. Rev. 115, 120 (1986).

244. And, when Congress does legislate, its message is frequently incomplete or equivocal. See, for example, one of the Motor Vehicle and Schoolbus Safety Amendments of 1974,15 U.S.C. $\$ 1410 \mathrm{~b}(\mathrm{~b})(1)$ (1982). This legislation responded to a 1972 Department of Transportation standard requiring automobiles eventually to have passive restraints (in the form of airbags or automatic seatbelts) and, in the interim, to include iguition interlocks that would prevent travel until manual seatbelts were fastened. The amendment prohibited the agency from requiring compliance through an interlock or continuous buzzer. Was Congress indicating broad disapproval of forcing Americans to buckle up, or was it simply rejecting one particular method of compulsion? Did it endorse the agency's underlying decision ultimately to require some form of passive restraint (e.g., airbags) as standard equipment in all automobiles? The subsequent decade of agency equivocation on the passive restraint issue, which reflected the differing views of three administrations, is detailed in Motor Vehicle Mfrs. Ass'n v. State Farm Mut. Auto. Ins. Co., 463 U.S. 29, 34-38 (1983).

245. Bruff, supra note 59, at 232; see also Wellington, The Nature of Judicial Review, 91 Yale L.J. 486, 489-90 (1982) (arguing that delegated authority rarely will be cut back because needs that initially prompted delegation will still exist, and that even when this is not so, "[i]t is the rare case in which neither a sizeable group of legislators nor a powerful private group has a large stake in the survival" of the agency). Congress's principal attempt to overcome some of the structural hurdles to controlling agency policy making through the full legislative process-the legislative veto-has been blocked. See INS v. Chadha, 462 U.S. 919 (1983); Process Gas Consumers Group v. Consumer Energy Council of Am., Inc., 463 U.S. 1216 (1983); Consumers Union of United States v. FTC, 463 U.S. 1216 (1983).

246. See Bruff, supra note 220 , at 457 ; Levin, supra note 76 , at 272 ; McGowan, supra note 59 , at 1131 .

247. Congress has exempted itself from the APA restrictions on ex parte contacts. See 5 U.S.C. § 557 (d)(2) (I982). 
whatever policy direction they represent tends to be direction by individual legislators, not by the legislative branch. The control over agency policy wielded by a powerful committee or chairperson may in some cases be substantial, but it is neither the practical nor the constitutional equivalent of policy direction by Congress. ${ }^{248}$

In sum, although Congress theoretically holds ultimate power over the content of regulatory policy, in fact the President has a singular ability to exploit the opportunity for social and economic policy making presented by broadly delegative statutes. ${ }^{249}$ Of course, disparities in the personal and political skills of individual Presidents and their key advisors will cause variations in the tenor and level of White House direction. The sheer magnitude of federal regulation will resist comprehensive management by even the most formidable Chief Executive. Whether or not the full potential for presidential control is actually achieved, however, few observers would disagree that the President is likely to come out significantly ahead of any other branch in harnessing and directing the stream of regulatory policy-making power. ${ }^{250}$

For these reasons, whatever supervision "the political branches" will exert over agencies' exercise of the authority to interpret regulatory statutes is most likely to emanate from the Chief Executive, not from the legislature. As a practical matter, then, the choice between independent judgment and deference rarely will be a choice between control by the courts and control by Congress. Indeed, although

248. Committee composition rarely is representative of Congress as a whole. See Weingast \& Marshall, The Industrial Organization of Congress; or, Why Legislatures, Like Firms, Are Not Organized as Markets, $96 \mathrm{~J}$. Pol. Econ. \& Indus. Organization 132, 149-52 (1988) (collecting data demonstrating that "members of the relevant committee or subcommittee significantly differ from the rest of the House"); see also Levin, supra note 76, at 272-73 (noting, inter alia, that committees "tend to be heavily biased in favor of members whose home districts have a parochial interest in the committee's business," and that oversight tends to be conducted largely by staff) (footnote omitted); Melnick, The Politics of Partnership, 45 Pub. Admin. Rev. 653, 655 (1985) (noting that efforts to make subcommittees representative "were abandoned as each member sought a piece of the action and was allowed to choose the type of action he or she favored") (footnote omitted). That committees may be dominated by members sympathetic to groups with a special interest in the regulatory program implicates the constitutional concern with structuring the legislative process to minimize the problem of factions. See Bruff, supra note 220 , at 457 n.29.

249. Professor Bruff has suggested that the President lacks strong incentives to intervene in regulation "because he bears only attenuated political responsibility for decisions made in the agencies and because intervention is likely to be a zero-sum game from his standpoint-he trades the pleasure of one constituency for the hostility of another." Bruff, supra note 59, at 233. This analysis may, however, underestimate the incentives of a president (like Ronald Reagan) who, because of a strong ideological reaction to the fact or the outcome of regulation, deliberately sets out to identify regulatory reform as a key part of his political agenda.

250. Thus, for example, even Professor Bruff's careful assessment of the many obstacles to presidential control agrees that "[p]residential oversight of the agencies has a potential to be unitary and consistent that the other branches cannot match." Id. 
Cheuron speaks as if the selection of interpretive model pitted the judiciary against the "political branches" plural, the Court at one point appears to acknowledge that the choice is really between control by the courts and control by the President:

Courts must, in some cases, reconcile competing political interests, but not on the basis of the judges' personal policy preferences. In contrast, an agency to which Congress has delegated policymaking responsibilities may, within the limits of that delegation, properly rely upon the incumbent administration's views of wise policy to inform its judgments. While agencies are not directly accountable to the people, the Chief Executive is, and it is entirely appropriate for this political branch of the Government to make such policy choicesresolving the competing interests which Congress itself either inadvertently did not resolve, or intentionally left to be resolved by the agency charged with the administration of the statute in light of everyday realities. ${ }^{251}$

Thus, Cheoron's exaltation of deference as the ordained course of a dutiful judiciary demurring to representative democracy ultimately comes to rest on the proposition that presidential control of regulatory policy addresses the constitutional concerns generated by the administrative state.

\section{B. The Constitutional Implications of Presidential Control}

Those constitutional concerns, as suggested earlier, ${ }^{252}$ are twofold. The legislative delegation of regulatory authority implicates separation of powers by threatening to undermine structural protections against the accumulation (and consequent abuse) of power. In addition, delegation implicates what might be called the "legitimacy ideal" by alienating the power to define public policy from the people's elected representatives. ${ }^{253}$ Cheuron offers presidential direction of administra-

251. Cheuron, 467 U.S. at $865-66$. The Court's statement that the agency may rely on the President's view "within the limits of [the congressional] delegation," id. at 865 , might appear, at first blush, to be a significant caveat. Recall, however, that earlier in the opinion, ambiguity is equated with delegation, and judicially enforceable statutory "limits" are defined as only those legislative expressions that are precise and unequivocal. See id. at 843-44.

252. See supra notes 57-64, 103-05 and accompanying text.

253. By using the term "legitimacy" to refer to such concerns about who determines public policy, I do not mean to suggest that this is the only dimension in which we assess the rightfulness or validity of government action. Norm elaboration is but one of the functions government performs, and the benchmarks of "legitimate" action will vary with context. For example, when government as law enforcer would impose penalties, the criteria of legitimacy include prior, reasonably clear and certain warning. See, e.g., Boyce Motor Lines v. United States, 342 U.S. 337, 340 (1952) ("[A] criminal statute must be sufficiently definite to give notice of the required conduct to one who would avoid its penalties, and to guide the judge in its application."). And, as noted earlier, the concern that responsibility for policy definition has been transferred from the legislature to an unelected bureaucracy is not the only legitimacy interest implicated by agency 
tive discretion (including the power to select among the set of rational statutory meanings) as responsive to this latter concern. But presidential control over domestic regulatory policy cannot cure the legitimacy problems posed by delegation unless the traditional conception of the legitimacy ideal is fundamentally altered. And any such effort at reconceptualization must confront the severe separation of powers dangers posed by the convergence of regulatory power in the hands of the Chief Executive.

1. The Legitimacy Ideal and Presidential Control of Regulatory Policy. Just as nondelegation analysis provided the forum in which the Supreme Court confronted and worked through the separation of powers implications of the growth of agencies, so the doctrine has been the medium for expressing and examining the legitimacy concerns raised by delegative statutes. The legitimacy ideal, and in particular its relationship to a prohibition on delegation, owes much to the social contractarian principles of John Locke's Second Treatise of Government. ${ }^{254}$ From the premise that the right to legislate resides initially in every member of the community, Locke reasoned that government could legitimately establish binding social policy only because, and to the extent that, the people confer such power in the constitution by which they create the state. ${ }^{255}$ The terms of this original grant simultaneously create and constrain government's lawmaking authority:

The power of the legislative, being derived from the people by a positive voluntary grant and institution, can be no other than what that positive grant conveyed, which being only to make laws, and not to make legislators, the legislative can have no power to transfer their authority of making laws and place it in other hands. ${ }^{256}$

action. See supra note 212 (comparing "policy-making" and "scope of authority" legitimacy). It is, however, the central legitimacy problem raised by the delegation of regulatory authority.

I describe the substitution of administrators for Congress as a threat to the "legitimacy ideal" because, even putting aside the complications introduced by contemporary agencies, we have never perfectly realized a state in which public policy is defined exclusively by the people's representatives. See, e.g., Wellington, supra note 245 , at 500 ("In a representative democracy, value determinations are made, and are meant to be made, by many actors who cannot possibly be described as 'our elected representatives.' ").

254. J. Locke, The Second Treatise of Government, §§ 134-142, at 75-82 (T. Peardon ed. 1952).

255. Id.; see also id. $\S \S 131-132$, at 73-74. On the early Americans' agreement that "the Right to legislate is originally in every Member of the Community," see G. Wood, supra note 156 , at 164 .

256. J. Locke, supra note $254, \S 141$, at 81 . Locke's views found an echo in Thomas Jefferson's account of the defects in Virginia's government during the Confederation period. Reporting with outrage the House of Delegates' proposal to meet a perceived crisis in government by creating "a dictator, invested with every power legislative, executive and judiciary," Jefferson asked:

In God's name, from whence have they derived this power? .. . Our antient laws expressly declare, that those who are but delegates themselves shall not 
The legitimacy ideal thus forms a second major conceptual root of the nondelegation doctrine, a root independent of (although in sympathy with) the separation of powers root. ${ }^{257}$ As the guardian of legitimacy, nondelegation focuses on the type of power at issue and the nature of the entity exercising it; the doctrine, in its pristine form, insists that decisions of public policy be made only by the legislature to whom the people chose to entrust lawmaking power. As nondelegation analysis evolved, however, the perceived needs of the legitimacy ideal, like those of separation of powers, were gradually and subtly redefined.

The approach the Court took in the early, formalistic delegation cases $^{258}$ neatly accommodated the legitimacy ideal. So long as the sort of power delegated could be characterized as not "legislative," the lawmaking authority remained safely in its original constitutional repository. With the emergence of "intelligible principle" analysis, however, this easy response was no longer possible, for the analysis conceded that some lawmaking power was indeed being transferred out of the legislature. ${ }^{259}$ In this intermediate stage of nondelegation development, legitimacy was secured through the requirement that Congress itself perform the "essential legislative function" of setting the "primary standards." 260 Although the people's designated representatives might no longer make all policy choices, they would continue to make the kinds of choices that really matter. When Yakus finally restated the nondelegation standard in terms of the control, rather than the nature, of power, ${ }^{261}$ the Court's conception of the needs of the legitimacy ideal again modulated. A delegation is permissible under Yakus so long as it contains standards "sufficiently definite and precise to enable Congress, the courts and the public to ascertain whether the [agency] ... has conformed to those standards."262 Thus, from an original em-

delegate to others powers which require judgment and integrity in their exercise. ... The same laws forbid ... a transfer of their powers into other hands and other forms, without consulting the people. They never admit the idea that these, like sheep or cattle, may be given from hand to hand without an appeal to their own will.

T. Jefferson, supra note 165 , at $126-27$.

257. See, e.g., Industrial Union Dep't v. American Petroleum Inst., 448 U.S. 607, 672-73, 685-86 (1980) (Rehnquist, J., concurring in the judgment). As Professor Monaghan has observed, the importance of both separation of powers and the social contract to late 18th century political theory reflects Americans' pervasive concern with "limited government." Monaghan, supra note 2, at 32.

258. See supra notes 114-24 and accompanying text.

259. See supra notes $134-41$ and accompanying text.

260. A.L.A. Schecter Poultry Corp. v. United States, 295 U.S. 495, 530 (1935); Panama Refining Co. v. Ryan, 293 U.S. 388, 426 (1935). See generally supra notes 140-42 and accompanying text.

261. Yakus v. United States, 321 U.S. 414 (1944); see supra notes $143-48$ and accompanying text.

262. Yakus, 321 U.S. at 426. 
phasis on the generation of policy choices, the legitimacy focus shifted to the oversight of policy choices.

The maturation of nondelegation analysis strained the legitimacy ideal, but the central thread was not broken. Oversight of agency policy making, Yakus asserted, would come from the people and from the legislature, with courts assisting "in a proper proceeding to ascertain whether the will of Congress has been obeyed."263 After establishing an initial framework within which the agency was to act, Congress would monitor the agency's lawmaking and reenter the field to provide additional guidance or correct administrative mistakes. Writing three years after Yakus, Louis Jaffe elaborated on this assumption:

The grant of general powers, however justified, implies a responsibility for close legislative attention to the course of administration. The legislature must be ready to intervene when administration runs into crucial issues for the settlement of which the existing standard is an inadequate guide. When such issues arise, there is no longer the excuse that the legislature is without the time, the information or the competence to deal with them. ${ }^{264}$

The creation of the administrative state was thus legitimated by moving from a model in which the legislature controls policy making through initiation to a model in which it controls policy making through supervision and reaction.

Yakus's assumptions-that Congress possessed the will and the ability to keep pace with the growth of regulatory power; that the process of interpreting regulatory statutes would be a simple matter of finding and enforcing the legislative "will"-may now seem sheer Pollyannaism. Nevertheless, a vision of the administrative state that retained Congress as the control center of domestic public policy making was, if ultimately unrealistic, essentially true to the legitimacy ideal. A vision of the administrative state that would place the President in this position-Cheoron's vision-cannot make the same claim. ${ }^{265}$

Admittedly, Cheuron's vision is born of real need. Congress's failure to impart significant direction to administrative policy makingeither by initiation or by oversight and reaction-has created a disquieting void. In the quest for a way to secure the reality of regulatory power within the framework of representative democracy, it is tempting to seize on the fact that Congress is not the only branch elected by the people and from this to take constitutional comfort in the prospect of presidential direction of the administrative state. However, the Presi-

263. Id.

264. Jaffe, An Essay on Delegation of Legislative Power: I, 47 Colum. L. Rev. 359, 366 (I947).

265. The discussion throughout refers to domestic policy making because in the area of foreign affairs the President's claim to an independent policy-making prerogative stands on a different constitutional footing. See U.S. Const. art. II, $\$ 2$ (Commander in Chief, treaty power, power to appoint and receive Ambassadors). 
dent does not become the interchangeable stand-in for Congress as domestic policy maker simply because he also is elected. On the most pragmatic level, the Chief Executive reflects a very different political base, and speaks with a very different political voice, than does the legislature. ${ }^{266}$ More fundamentally, in our constitutional scheme the legitimacy ideal has not reduced-at least until now-to the epithet "popularly elected." Rather, the archetype of legitimate formulation of public policy has been Congress acting through a majority of each House with the President's concurrence or through two-thirds of each House without his concurrence. The proposition that when Congress fails to speak clearly on a regulatory issue the President is constitutionally warranted, in his own right, ${ }^{267}$ to take over the task must be recognized for what it is: the advocacy of a profoundly different conception of legitimacy. ${ }^{268}$

Given our seemingly irreversible commitment to the administrative state and Congress's apparent inability to direct it meaningfully, a

266. Although there may be no consensus on whether the President tends to the more or less representative of the people's will than Congress, few would disagree that he is representative in a different way. See generally Mashaw, Prodelegation: Why Administrators Should Make Political Decisions, 1 J.L. Econ. \& Organization 81, 95 \& n.6 (1985). Explanations for the difference sound in such widely diverse sources as demographics, the constitutional mechanics of election, the impact of the national political party system, public choice theory and psychology. For example, because of the electoral college system, the constituency of a president is often predominantly urban, while that of Congress is oriented towards rural and small-town populations. See Mendelson, Separation, Politics and Judicial Activism, 52 Ind. L.J. 313, 316 (1977) ("a presidential candidate who has substantial support in some fifteen or twenty major metropolitan areas is virtually assured of victory"); see also N. Polsby, Congress and the Presidency 14-15 (3d ed. 1976) (presidential candidates tend both to be chosen from populous states with large electoral college impact and to have made alliances with urban interest groups). Some have suggested that the effects of this difference in electoral base are enhanced by the likelihood that the President will be far more conscious than members of Congress of his role in history-leading him to emphasize broader, less parochial concerns and to reflect adventurous, less cautious attitudes. See Rossiter, President and Congress in the 1960's, in Continuing Crisis in American Politics 86, 103-06 (M.D. Irish ed. 1963); cf. Mashaw, supra, at 95 (discussing theory that voters choose members of Congress on basis of ability to funnel government largesse to the district and Presidents on basis of difference candidate might make to general government policies).

267. I say "in his own right" for, if the theory is that the President is entitled to control regulatory policy because Congress intends him to do so, then his claim comes merely as a delegee of the legislature; an assertion that independent judgment interferes with this sort of claim would be simply a species of the "judicial usurpation" argument discussed supra notes 65-208 and accompanying text.

268. This is not to deny that, in the absence of clear congressional guidance, the President may be the part of government most likely to make necessary decisions of regulatory policy in a politically responsive manner. However, any attempt to fashion a constitutional case for the deferential model on the basis of presidential control over agency policy making ought to acknowledge that the President, in the traditional understanding of the constitutional allocation of authority, has no independent claim to domestic lawmaking power. 
reconception of legitimacy principles to support an independent presidential domestic policy-making prerogative should perhaps be attempted. ${ }^{269}$ However, Cheoron's facile pronouncement that deference is necessary because the President's elected status entitles him to direct the course of regulatory policy - to the point of constitutionally disabling the judiciary from exercising even the modest slice of policy-making power represented by statutory interpretation-appears not even to recoguize that a major theoretical transformation has occurred. In such obliviousness there is danger. Constructing a new legitimacy ideal would be essential to support this radical reconception of the President's constitutional role, but would not, of itself, be sufficient. Advocates of this revised view of the appropriate allocation of policy-making responsibility must also be prepared to explore what it would mean for the balance of power in government.

2. Separation of Powers and Presidential Control of Regulatory Policy. - I have suggested that we might use the phrase "dynamic equilibrium" to describe the constitutional structure which emerged from the uniquely American understanding of separation of powers. ${ }^{270}$ Characterizing the equilibrium as "dynamic" implies that shifts in the balance of power among the branches will not necessarily be either constitutionally improper or politically unhealthy. Our history has seen cycles in which first Congress, and then the President, has enjoyed relative ascendancy. ${ }^{271}$ Sometimes the will of the people is expressed more clearly through one branch than through another, and then a change in the

269. The recent outburst of scholarly interest in presidential involvement in, and control of, the regulatory process, e.g., Symposium, The Uneasy Constitutional Status of the Administrative Agencies, Part II: Presidential Oversight of Regulatory Decisionmaking, 36 Am. U.L. Rev. 443 (I987) [hereinafter Symposium], may signal the beginning of such an attempt. This would not be the first effort dramatically to reshape the legitimacy ideal to reconcile the reality of administrative policy making. The "interest representation" model of the 1970s sought to legitimate agency action by opening administrative processes to all affected interests, with the aim of replicating the legislative process. "Agency decisions made after adequate consideration of all affected interests would have, in microcosm, legitimacy based on the same principle as legislation ...." Stewart, supra note 59, at 1712. As Stewart's perceptive analysis predicted, see id. at 1760-90, 1802-05, interest representation ultimately did not prove a satisfying response to the legitimacy dilemma. See Garland, supra note 26, at 511-12,581-86. With the failure of both true legislative control and the notion of agency-as-surrogate-legislature, it is perhaps inevitable that the President emerge as the focus of the next generation of legitimation theory.

270. See supra text following note 202.

271. See Levi, Some Aspects of Separation of Powers, 76 Colum. L. Rev. 371, 371-72, 379-81 (I976); see also Mendelson, supra note 266, at 315 (suggesting that Congress and the President are likely to be evenly matched in "weak party eras"). Observing that "what the presidency is at any particular moment depends in important measure on who is President," Edward Corwin described the history of the presidency as "a highly discontinuous one." Significantly, though, even 30 years ago he had concluded: "Taken by and large, the history of the presidency is a history of aggrandizement . . ." E. Corwin, supra note 240, at 29-30. 
balance appropriately serves the democratic process. Indeed, the capacity for such adjustments and readjustments is itself an important part of the functioning of separation of powers. ${ }^{272}$ However, several factors now operating to affect the balance of power have little to do with differing degrees of political responsiveness. The commitment to pervasive intervention in the economic and social order that has vastly increased the level of extant federal power, the implementation of this commitment through broad delegations of power to entities outside Congress (and often squarely within the executive branch), and the structural and customary factors that favor the President in any struggle for control of the regulatory bureaucracy have coalesced to create a persistent and decided tilt toward presidential dominance of large sections of domestic policy. ${ }^{273}$

This shift in the balance of power might be defended by observing that the Framers were determined to secure a strong Chief Executive vis-à-vis the legislature. ${ }^{274}$ Without doubt, this concern is evident in the Convention debates and the Federalist Papers. ${ }^{275}$ The conclusion does not follow, however, that the gradual emergence of the President as chief architect of social policy was part of the constitutional plan.

When the colonists declared their independence from England, the preeminent focal point of their discontent was the unchecked power of the executive, in the person of the Crown. ${ }^{276}$ The determina-

272. See McGowan, supra note 59, at 1119 ("One of the values of the separation concept is that it generates an ebb and flow-a constant shifting, if you please-in the relative strengths of the three branches, which operates to contain and to ameliorate the inevitable tensions between them."); see also Strauss, supra note 59, at 604 ("With room left for interaction, change and growth over time, the relative strength of President and Congress could change with the political climate, without offending the constitutional structure.").

273. See Black, The Working Balance of the American Political Departments, 1 Hastings Const. L.Q. 13, 17 (1974). Professor Black notes that both Congress and the President know that Congress, "given the will," could take back the power it has given, or allowed to slip, away. 1d. at 18. However, little in recent years would cause a President to take very seriously the prospect of Congress summoning the "will" to reclaim any significant portion of the regulatory power it has delegated. See generally supra notes 243-45 and accompanying text (discussing obstacles to congressional amendment or repeal of regulatory statutes).

274. The Court frequently invokes this argument in cases concerning the relationship among Congress, the President and administrative agencies. See, e.g., Bowsher v. Synar, 478 U.S. 714, 727 (1986); INS v. Chadha, 462 U.S. 919, 946-51 (1983); Buckley v. Valeo, 424 U.S. 1, 129 (1976).

275. See, e.g., 2 M. Farrand, The Records of the Federal Convention of 1787, at 74-78 (rev. ed. 1966); The Federalist No. 51, supra note 185, at 350 (J. Madison); The Federalist No. 73, at 494 (A. Hamilton) (J. Cooke ed. 1961); see also The Federalist No. 48, supra note 157, at 332-38 ( $\mathrm{J}$. Madison) (argning that in a representative republic, the legislature poses greater danger than the executive).

276. "Whatever the actual responsibility of royal authority for the dissatisfactions and frustrations in American society, by 1776 the English Crown had come to bear the full load .... The Crown had become, in a word, a scapegoat for a myriad of American ills." G. Wood, supra note 156, at 82; see supra note 161 and accompanying text. 
tion to avoid executive supremacy became the lodestar of the new American political theory. "When Americans in 1776 spoke of keeping the several parts of the government separate and distinct, they were primarily thinking of insulating the judiciary and particularly the legislature from executive manipulation."277 Accordingly, in the governmental structures created during this early period (principally, the state constitutions), dominance of the legislature was expressly or effectively assured. ${ }^{278}$ Legislative supremacy, however, simply brought a new set of evils. The legislatures in which the Americans had placed such faith confiscated property, disrupted the collection of debts and were perceived as generally responsible for unsettling the orderly progress of mercantile and social development. ${ }^{279}$ Jefferson's comments on the course of affairs in Virginia epitomized the ultimate disillusionment with the legislative dominance of the Confederation period:

All the powers of government, legislative, executive, and judiciary, result to the legislative body. The concentrating [sic] these in the same hands is precisely the definition of despotic government. It will be no alleviation that these powers will be exercised by a plurality of hands, and not by a single one. 173 despots would surely be as oppressive as one. ... As little will it avail us that they are chosen by ourselves. An elective despotism was not the government we fought for . . . .280

By the mid-1780s, the legislature had become almost the bugbear that the executive had been a decade earlier. ${ }^{281}$

The extraordinary concern displayed by those who drafted the Constitution to provide for a strong Executive must be understood against this background. The delegates who met in Philadelphia to structure the new government began with the assumption that the legislative branch would, by the nature of things, be the most powerful. As Madison argued, the lawmaking power is intrinsically "more extensive and less susceptible of precise limits" than the executive or judicial powers. ${ }^{282}$ Determined to provide against the danger that ineluctably

277. G. Wood, supra note 156, at 157. Professor Wood has suggested that it is difficult for us now to appreciate the "awful fear" in which the executive was held during this period. Id. at 149 .

278. See supra note 163 and accompanying text; see also G. Wood, supra note 156 , at 149 (noting that "emasculation of their governors lay at the heart of the[] constitutional reforms of 1776 ").

279. See G. Wood, supra note 156, at 403-09. Professor Wood has suggested that economic conditions in this period may in fact have been quite stable and healthy; however, the perception at the time was quite the opposite. See id. at 394-95.

280. T. Jefferson, supra note 165 , at 120 .

281. See G. Wood, supra note 156 , at $340,409$.

282. The Federalist No. 48 , supra note 157, at 334; see also The Federalist No. 52, at 350 (J. Madison) (J. Cooke ed. 1961) ("In republican government the legislative authority, necessarily, predominates.").

Madison had recognized, and worried about, the apparent illimitability of the legislative power at least as early as $\mathbf{1 7 8 5}$. See Letter from J. Madison to C. Wallace (Aug. 23, 
follows power, the Framers divided the legislature within itself and set out to create an executive that could serve as a meaningful external counterweight. 283 Their emphasis on shoring up the President's position arose not from the expectation that he would emerge as the dominant domestic policy-making force, but rather from sad experience that no branch could be trusted with too much power. That they aimed to correct a perceived imbalance in favor of the legislature rather than to facilitate a reversion to executive supremacy is underscored by various choices they made during the drafting process. Although they gave the President the appointment power, they required him to find Senate concurrence when filling important vacancies in the executive branch. Although they granted him the authority to veto legislation, they rejected the proposal that this power be absolute. And, ultimately, they subjected him to an impeachment process controlled by Congress. ${ }^{284}$

Thus, history affords no basis for assuming that the constitutional structure was set up to favor a predominant role for the President. Indeed, to divorce the Framers' concern for establishing a strong Chief Executive from its context poses a grave risk of using their words to

1785), reprinted in 8 Papers of James Madison 350, 351 (R. Rutland, W. Rachal, B. Ripel \& F. Teute eds. 1973) ("1f it were possible it would be well to define the extent of the Legislative power but, ... the nature of it seems in many respects to be indefinite."). He recognized that the new government had to be structured on the principles that "power is of an encroaching nature, and that it ought to be effectually restrained from passing the limits assigned to it." The Federalist No. 48, supra note 157, at 332 . A power the legitimate limits of which were both extensive and difficult to perceive thus posed a uniquely difficult problem of control:

$1 t$ is not unfrequently a question of real-nicety in legislative bodies, whether the operation of a particular measure, will, or will not extend beyond the legislative sphere. On the other side, the executive power being restrained within a narrower compass, and being more simple in its nature; and the judiciary being described by land marks, still less uncertain, projects of usurpation by either of these departments, would immediately betray and defeat themselves.

Id. at 334.

283. See The Federalist No. 51, supra note 185 , at 350 ; The Federalist No. 62 , at 418-19 (J. Madison); The Federalist No. 63, at 424-27 (J. Madison) (J. Cooke ed. 1961); see also G. Wood, supra note 156 , at $559,550-51,584$. An independent judiciary also came to be perceived as essential to counterbalance the dangerous legislative power. M. Vile, supra note 101 , at 158; G. Wood, supra note 156 , at $450-63,550-52$.

284. The need to correct an unintentionally created imbalance was explicitly part of Madison's defense of the new Constitution's structure:

The founders of our republics have so much merit for the wisdom which they have displayed, that no task can be less pleasing than that of pointing out the errors into which they have fallen. A respect for truth however obliges us to remark, that they seem never for a moment to have turned their eyes from the danger to liberty from the overgrown and all-grasping prerogative of an hereditary magistrate, supported and fortified by an hereditary branch of the legislative authority. They seem never to have recollected the danger from legislative usurpations; which by assembling all power in the same hands, must lead to the same tyranny as is threatened by executive usurpations.

The Federalist No. 48, supra note 157 , at 333 (J. Madison). 
sanction precisely the sort of harm they had determined to avoid: a dangerous concentration of authority in one power center of government. Those who drafted and defended the Constitution perceived in Congress the threat of overreaching because the legislative power was difficult to delimit and, hence, to control. ${ }^{285}$ When large portions of this power move away from Congress through delegation, however, Madisonian fears of encroachment should shift correspondingly from the original repository of the lawmaking power to its new possessorespecially when the delegated power tends to flow towards a recipient that already holds the considerable power to execute the laws and that has been structured to maximize the potential for resolute, consistent exercise of power. As Madison reminded Jefferson in the early days of the new constitutional government, "Wherever the real power in a Government lies, there is the danger of oppression."286

One might concede this history yet nonetheless advocate presidential assumption of the role of chief regulatory policy maker by observing, as the Justices are wont to do, that the Framers were "practical statesmen" who intended, above all, to establish an effective system of government. ${ }^{287}$ Regulatory programs of ever increasing scope and complexity have grown like Topsy, creating, in the view of many observers, a desperate need for coordination and prioritization. ${ }^{288}$ The movements of the 535-member Congress, at best elephantine, are too frequently paralyzed by the competing demands of a plethora of interest groups. By contrast, the President, with his national constituency and outlook and his position as the unitary head of a hierarchy of policy analysts and technical experts, is said to have both the perspective and the structural ability to undertake the difficult task of shaping an integrated regulatory policy. ${ }^{289}$

285. See supra note 282 and accompanying text.

286. Letter from J. Madison to T. Jefferson (Oct. 17, 1788), reprinted in 14 Papers of Thomas Jefferson 16, 19 (J. Boyd ed. 1958). Madison's comment was made in the particular context of his concern that the proposed Bill of Rights would be a mere "parchment barrier[]" against the wishes of the majority, in whom he perceived the "real power" of the new government to lie. Id. Jefferson's response, which was more optimistic about the proposed amendments, contained a somewhat different assessment of the quarter from which danger should be expected: "The tyranny of the legislatures is the most formidable dread at present, and will be for long years. That of the executive will come in it's [sic] turn but it will be at a remote period." Id. at 661 .

287. See, e.g., Industrial Union Dep't v. American Petroleum Inst., 448 U.S. 607, 673 (1980) (Rehnquist, J., concurring in judgment); Buckley v. Valeo, 424 U.S. 1, 121 (1976).

288. See, e.g., ABA Comm'n on Law and the Economy, supra note 220, at 68-73. This complaint is not new. See The President's Comm. on Administrative Management, supra note 84 . See generally P. Shane \& H. Bruff, supra note 221, at 343-44 (surveying the work of various study commissions in the last 50 years and noting "a surprising (and depressing) similarity of perceptions about the problems and necessary reforms").

289. For a specific proposal to accomplish such presidential coordination, see Cutler \& Johṇson, supra note 59, at 1414-17. The ABA Commission on Law and the 
Looking once again to history, such utilitarian arguments for the allocation of power among the branches are not constitutionally irrelevant. Montesquieu had offered two distinct justifications for organizing government on principles of separation of powers: such a structure prevents the concentration of power, thereby discouraging tyranny; in addition, it makes possible specialization of function, thereby furthering efficient government. ${ }^{290}$ The American vision of separation of powers enthusiastically embraced the efficiency as well as the control strand of Montesquieu's theory. The unitary executive was praised as possessing the capacity for resolve, expeditiousness and secrecy needed to maintain domestic order and conduct foreign affairs, while the bicameral legislature was lauded for reflecting the diversity of interests needed to craft sound policy. ${ }^{291}$ In spite of these paeans, though, one is left with the sense that the Framers' insistence on the efficiency of the constitutional structure was part of their almost Panglossian captivation with separation of powers. This organizational principle was the best

Economy endorsed a very similar proposal. See ABA Comm'n on Law and the Economy, supra note 220 , at $68-91$.

The insights of Arrow's Theorem offer a new rallying point for proponents of enhanced presidential control. By proving that a fair system of collective decision making by majority rule cannot consistently generate rational choices, see $\mathrm{K}$. Arrow, Social Choice and Individual Values (2d ed. 1963), the Theorem can be invoked to support moving regulatory policy making out of the legislative arena and into a centralized, technocratic setting that can more closely approximate a dictatorship (in which consistently rational policy choice is achievable). See, e.g, Mashaw, supra note 266, at 95-99. See generally Mayton, The Possibilities of Collective Choice: Arrow's Theorem, Article I and the Delegation of Legislative Power to Administrative Agencies, 1986 Duke L.J. 948.

290.

The executive power ought to be in the hands of a monarch, because this branch of government, having need of despatch [sic], is better administered by one than by many: on the other hand, whatever depends on the legislative power is oftentimes better regulated by many than by a single person.

Montesquieu, supra note 157, bk. XI, ch. 6, at 168; see also id. at 166-67 (discussing why a representative legislature is the best-suited to making laws, and ill-suited to executing them).

By attributing to Montesquieu a judgment about "efficient" governmental organization, I do not mean to imply, anachronistically, an I8th century consciousness of concepts of cost minimization and optimal resource allocation, but rather that The Spirit of Laws evaluated structural forms with an eye to not only their ability to forestall despotism, but also their capacity to achieve desired results directly and reliably. For example, Montesquieu's conclusion that the army ought to be under the direction of the executive rather than the legislature rests on both the concern for effective functioning ("It is natural for mankind to set a higher value upon courage than timidity, on activity than prudence, on strength than counsel. Hence the army ... will naturally slight the orders sent them by a body of men whom they look upon as cowards ....”), id. at 173, and the fear of tyranny (" $[A]$ s soon as the troops depend entirely on the legislative body, it becomes a military government ....."). Id.

Locke also defended separation of powers on both efficiency and control grounds. See M. Vile, supra note 101 , at 61-62.

291. See, e.g., The Federalist No. 70 , supra note 240 , at $472,475-76$ (A. Hamilton). 
of all possible worlds because it thwarted tyranny and, at the same time, enhanced efficiency by enabling specialization of function. When they actually came down to choosing between control and efficiency, however, the former won out. ${ }^{292}$ The best evidence of this is the structure they ultimately created. If they perceived efficiency to flow from the opportunity for specialization and from the molding of each part's organizational structure to suit the demands of a particular governmental task, ${ }^{293}$ then their deliberate decision to depart from absolute division of powers-their conscious choice to cause each branch to share its power with an "unsuited" and hence "inefficient" branch ${ }^{294}$-reveals the Framers' priorities.

That the equilibrium of government power was expected by those "practical statesmen" to be dynamic rather than static, to be capable of shifting to provide effective government in the face of the changing demands of a developing society, cannot obscure the fact that the core idea was equilibrium: a balance and counterbalance of power centers in government. How far this tension was to extend-whether the original vision was of "a harmony of purposes differently fulfilled"295 or of "permanent guerilla warfare"296_-may be debated, but the writings of Madison and others make clear that the friction was intended to be real and to impede the operations of each branch to some degree. Efficiency, though a powerful card, was not to be a trump. As one commentator has pointed out: "[T]he same Separation of Powers with its corollary 'checks and balances' that was designed to impede evil goverument must pari passu impede good government . . . ."297 Put differently, and perhaps more accurately, in a constitutional system built upon separation of powers, "good" government is defined not simply

292. By treating control and efficiency as, in the end, mutually exclusive, I follow the conventional approach. See, e.g., Myers v. United States, 272 U.S. 52, 293 (1926) (Brandeis, J., dissenting) ("[S]eparation of powers was adopted . . not to promote efficiency but to preclude the exercise of arbitrary power."); see also INS v. Chadha, 462 U.S. 919, 944 (1983) ("Convenience and efficiency are not the primary objectives-or the hallmarks - of democratic government ...."). It is not inevitable, however, that they be perceived as dichotomous. The efficiency assessment could be set up to reflect control as a value; if protection from autocracy were included on the benefit side of the equation, then the balance struck in the constitutional structure might be defended as "efficient." Cf. Macey, supra note 55, at 247-49 (discussing "the establishment of constitutional mechanisms and institutions that raise the costs of rent-seeking without imposing burdens on society greater than the savings derived from the diminution in such rent-seeking").

293. Examples include giving foreign policy and domestic peacekeeping to a unitary executive, and lawmaking to a representative assembly.

294. Examples include congressional participation in the warmaking and treaty powers, U.S. Const. art. $1, \S 8, \mathrm{cl}$. 11, art Il, § 2, cl. 2, and the presidential power to veto legislation, U.S. Const. art. $1, \S 7$, cl. 3.

295. Levi, supra note 271 , at 391 .

296. Schlesinger, First Lecture, in Congress and the Presidency: Their Roles in Modern Times 3 (1967).

297. Mendelson, supra note 266, at 313 . 
in terms of efficient government, but also in terms of government restrained. That the President may be the branch best suited to pilot the administrative state is not constitutionally irrelevant, but, as a constitutional justification for the allocation of power, it is by no means enough.

In sum, the dominance of the executive that has followed the delegation of regulatory power cannot be squared with the original commitment to separation of powers, any more than the emergence of the President as chief architect of regulatory policy can be justified under the traditional understanding of the legitimacy ideal. We might, then, simply reject the relevance of those original principles to the demands of contemporary government, abandoning separation of powers in favor of some new structural conception at the same time that we fashion a new theory of legitimacy. ${ }^{298}$ A decision of this magnitude, however, ought not be made by default, through an incremental acquiescence to presidential control of the regulatory process that is oblivious to the larger structural consequences.

Those original principles were central to a political theory that had been crafted by men who systematically canvassed the forms of government and self-consciously dissected their own experience with both executive and legislative dominance. ${ }^{299}$ Surely it is something more than "envelop[ing] ourselves in the mythology of the superhuman wisdom of the Founding Fathers" 300 to suggest that, before we discard their conclusions, we should think very carefully about what we are doing. Have we indeed good reason for believing that the Framers were wrong to assess the danger of concentrated power as greater, in the long run, than the danger of inefficiency? The Confederation period led them to conclude that government which moved too quickly in establishing and altering policy was, over time, less likely to make wise choices and more likely to threaten individual liberty. ${ }^{301}$ Therefore, they deliberately cre-

298. Cf. Miller, supra note 223, at 601-02:

The Executive- whoever is in the White House-will prevail. Let there be no doubt about that. That may not have been the intention of the Founding Fathers, but certainly it is the consensus of Americans today. The problem, as I have said, is how to make power-presidential power-that is necessary as tolerable or decent as possible. That should be the goal of constitutional scholarship.

299. Gordon Wood describes how Madison, for example, returned from the Continental Congress in the winter of 1785-86, convinced of the failure of the political theory of the Confederation, to embark upon an "intensive study of ancient and modern confederacies in search of an understanding of 'the science of federal government." "G. Wood, supra note 156 , at 472 .

300. Miller, supra note 223 , at 596 .

301. See, e.g., The Federalist No. 73, supra note 275, at 496 (A. Hamilton) (speaking of "the mischiefs of that inconstancy and mutability in the laws, which form the greatest blemish in the character and genius of our governments"); see also The Federalist No. 62, supra note 242, at 420 (J. Madison) ("To trace the mischievous effects of a mutable government would fill a volume."). On the Framers' conviction that an unbri- 
ated a lawmaking process that was slow, even cumbersome. In pursuing the vision of a forceful Chief Executive who can cut resolutely through regulatory policy dilemmas, minimizing the delay of consensus building and the frustration of political impasse, are we really ready to dismiss their fears as groundless, their precautions as unnecessary? ${ }^{302}$

Moreover, even if we are now prepared to rate efficiency more highly as a structural objective than control, are we so sure that encouraging presidential dominance of the regulatory process will yield better results? We have gradually become disillusioned with the idea that regulatory policy dilemmas have an objectively "correct" answer, discernible through the aggregation of enough information and the application of enough expertise. ${ }^{303}$ That disillusionment would seem to leave a democratic society little choice but to define "good" policy as that which represents the consensus of the citizenry. ${ }^{304}$ Led by their own

dled making and amending of laws destabilized the governments of the Confederation period, see generally G. Wood, supra note 156, at 405-07.

302. Compare those who argue that Congress should not be permitted to avoid political impasse by passing the buck to agencies under a broad or ambiguous delegation, e.g., Industrial Union Dep't v. American Petroleum Inst., 448 U.S. 600, 685-87 (1980) (Rehnquist, J., concurring in the judgment); J. Ely, Democracy and Distrust 132-34 (1980); McGowan, supra note 59, at 1128-30, with those who defend expansive delegation precisely because it makes possible regulatory programs that could not successfully negotiate the legislative process, e.g., Stewart, supra note 59, at 1695-96.

303 . On the birth and degeneration of our faith in a politically neutral administrative "expertise" that can ferret out an ascertainable "public interest," see Pierce \& Shapiro, supra note 58, at 1179; Smith, supra note 57, at 439-41; Stewart, supra note 59, at 1677-78, 1682-84; Sunstein, supra note 5, at 281-82.

304. Although contemporary American political thought comprises a range of different visions of democracy, all mainstream theories accept on some level the equation of "good" policy with the consensus of the governed. The equation is most direct and immediate for theories grounded in a pluralist vision: public policy is formed through the process of aggregating individuals" self-defined preferences; "good" policy is that which accords with the private preferences of a majority of the society (subject, perhaps, to a sphere of minority "rights" that constrains pursuit of the majority's preferences by imposing either an absolute bar or at least a high burden of justification as a predicate to government invading the "right"). See Sunstein, Interest Groups in American Public Law, 38 Stan. L. Rev. 29, 32-33 (1985).

The equation is more complex, and unsettled, for theories grounded in a republican vision. This vision, in both its classical and contemporary forms, denies that the goal of the democratic political process is merely to facilitate the aggregation of private preferences. See Michelman, Politics and Values or What's Really Wrong with Rationality Review?, 13 Creighton L. Rev. 487, 492-99 (1979); Sunstein, supra, at 31-32. At the same time, however, modern republicanism is profoundly uncomfortable with that part of traditional republican theory that conceived of the "public good" as an objective phenomenon existing apart from (and hence definable independent of) the present wishes of the citizens. See Michelman, supra note 169, at 17-23. For neo-republicans, the most promising course between the Scylla of classical republican objectivity and the Charybdis of pluralist relativism appears to be an analysis that critiques some present values or practices on the basis of other values or principles already imminent in the American democratic tradition-a tradition that we, the people, have created over time. Thus, while unequivocably rejecting sheer majoritarianism, new republican theory 
experience to conclude that no single part of government could be trusted to speak authoritatively for the people, the Framers split the legislature into two houses and strengthened the executive so that several different expressions of the will of the governed might be heard. ${ }^{305}$ This original judgment that no one power center fully embodies the interests of the people seems to be borne out by contemporary observations of the different constituencies of Congress and the President. ${ }^{306}$ Can we nevertheless comfortably conclude that the quality of regulatory policy choices will be improved by legal rules that promote the convergence of policy direction in the President's hands?

Unless we are confident that these questions can be answered in the affirmative, and until we are prepared to undertake and justify a redefinition of the constitutional ground rules, invoking a presidential prerogative to direct agency policy making as a principle of decision in cases that concern the allocation of regulatory power is, at a minimum, foolishly premature. If we remain committed to separation of powers as a central structural credo, then choices such as the one made in Chevron are steps in the wrong direction. At stake in Chevron was the fate of one relatively small but not insignificant slice of the regnlatory power pie: the authority to interpret the statutes that define the policy-making universe. The Court's resolution deliberately moves that power squarely into the President's domain. By relinquishing the authority to determine statutory "meaning" to agencies whenever Congress has failed to speak clearly and precisely, Chevron enlarges the quantum of administrative discretion potentially amenable to direction from the White House. It then goes even further and exhorts agencies to exercise this discretion, not by attempting to intuit and realize the objectives of the statute's enactors, but by pursuing the regulatory agenda of the current Chief Executive.

Had the Court instead chosen the independent judgment model, this slice of power would have been placed beyond the reach of the executive in the hands of another branch. The negative act of withholding authority from a power center that tends to have too much could have yielded positive constitutional benefit. Concededly, independent judgment is not a constitutional panacea. To the extent that

would ultimately look to the will of the people, as reflected in and reconstructed from the context of their past and present beliefs, to define the "public good." See, e.g., id. at 31-33.

305. The gradual recognition that "no department was theoretically more popular and hence more authoritative than any other," and the concomitant development of the idea that "[a]ll parts of the government were equally responsible but limited spokesmen for the people" was pivotal to the transition from Confederation political theory to the political theory of the Constitution. G. Wood, supra note 156, at 550, 599.

306. See supra note 266 and accompanying text. See generally Sargentich, supra note 59, at 436 ("To rely on [the President] to monitor the administrative process on behalf of all public interests is to risk ignoring that the President's political commitments reflect a subset of those of the polity."). 
giving meaning to regulatory statutes involves lawmaking as well as law finding, judicial control over the interpretive process does not satisfy the legitimacy ideal any better than does presidential control. ${ }^{307}$ However, as the ideal has traditionally been defined, it can be satisfied by little short of some mechanism for remanding important policy questions raised by interpretation to the legislative process for clarification. Several commentators have called for such a remand mechanism, ${ }^{308}$ and this would, at least in theory, be the most direct response not only to legitimacy but also to separation of powers concerns. ${ }^{309}$ While searching for the optimal solution, though, we ought to be alert to take what we can get. Allocating principal responsibility for interpreting regulatory statutes to the judiciary would significantly further separation of powers by placing power where it will counterbalance, rather than contribute to, the concentration of regulatory authority in the executive. In the interminable struggle to make peace between the Constitution and the administrative state, that would be no small victory.

\section{CONCLUSION}

Honoring the original commitment to separation of powers in the twentieth century administrative state requires a heightened sensitivity to attaining equilibrium among the power centers of government. Contriving the new balance does not mean we must forfeit all the advantages presidential direction can bring to the administrative process. Even were it possible to preclude presidential involvement in regulatory policy making-which, as a practical matter, it surely is not-the

307. Again, the discussion in the text is limited to policy-making legitimacy. If "scope-of-authority legitimacy" is taken into account, judicial control is indeed likely to serve legitimacy concerns better than would presidential control. See supra note 212 and accompanying text; see also Garland, supra note 26, at 585 (the President may not be the "best interpreter" of the intentions of the enactors); Levin, supra note 76, at 271 (judicial review can serve the democratic process by forcing the executive branch to adhere to the will of the majority expressed through legislative process).

308. The most obvious mechanism is invalidation of statutes on nondelegation grounds. See, e.g., T. Lowi, The End of Liberalism 300-01 (1979); Aranson, Gellhorn \& Robinson, supra note 130, at 63-67; Gerwin, supra note 2, at 379-91; Wright, Book Review, 81 Yale L.J. 575, 582-87 (1972). A less drastic approach would have courts use a clear-statement approach narrowly to construe grants of regulatory authority. The agency would thus be forced to return to Congress to obtain explicit confirmation of its authority to act. See generally Stewart, supra note 59, at 1697, 1788-89 (discussing the nature and limitations of a broad clear-statement approach). A very different sort of remand mechanism is Judge Ginsburg's proposal for a law revision commission on the national level. See Ginsburg, supra note 56, at 10I1-17.

309 . Whether the remand process-especially if it relied upon invalidation on nondelegation grounds-could be administered by judges in a principled fashion or would be successful in commanding meaningful congressional attention are hotly debated questions. See, e.g., K. Davis, Discretionary Justice 27-51 (1969); Mashaw, supra note 266, at 87-91; Stewart, supra note 59, at 1694-97; Symposium, The Uneasy Constitutional Status of Administrative Agencies, Part I: Delegation of Powers to Administrative Agencies, 36 Am. U.L. Rev. 295-442. 
result would simply be an imbalance of a different sort. What it does mean is that we must recognize the constant tendency of regulatory power to flow, centripetally, towards the head of the executive branch and think deliberately and carefully about where to find counterbalance for this tendency.

I have argued here that the Court in Chevron failed to do these things and, as a result, made a choice that skewed the balance even further. But the shortcomings of the Court's analysis in that case is only one manifestation of a larger problem. Just as statutory interpretation is but one aspect of the task of defining federal regulatory policy, so the choice of who holds the interpretive authority is but one dimension of the question of who controls the power that Congress has delegated. In the last few years, the Court has confronted several other dimensions of that question. It has considered who may appoint agency heads and who may remove them. ${ }^{310}$ It has considered whether agency actions may be disapproved by formal legislative action short of the full lawmaking process. ${ }^{311}$ It has considered whether the reasons for agency enforcement strategy may be subjected to judicial scrutiny. ${ }^{312}$ In each case, it has decided in favor of the President and the agency, and against the possibility of an external check by Congress or the judiciary.

The outcome in some or even all of those cases may be correct, but the Court's analysis surely has been inadequate. It continues to invoke the Framers' fear of legislative dominance, ${ }^{313}$ and disregards the fact that much of the power which bred that fear has passed out of Congress's grasp. It recalls the Framers' concern that the President be a strong and independent player in the power struggle ${ }^{314}$ and overlooks the superiority that structure and custom have given him in a world of delegated power. It emphasizes the safeguards that the full legislative process was intended to provide against ill-considered, unrepresentative policy choices ${ }^{315}$ and ignores the reality that much of our most significant policy making now occurs in an administrative process where substitutes for the original safeguards must somehow be provided. It casts agencies in the role of law executors, worries about shielding them from undue legislative or judicial management, ${ }^{316}$ and

310. See Bowsher v. Synar, 478 U.S. 714 (1986); Buckley v. Valeo, 424 U.S. 1 (1976).

311. See INS v. Chadha, 462 U.S. 919 (1983).

312. See Heckler v. Chaney, 470 U.S. 821 (1985).

313. See, e.g., Synar, 478 U.S. at 727; Chadha, 462 U.S. at 946 51; Valeo, 424 U.S. at 129.

314. See, e.g., Synar, 478 U.S. at 722-27 (emphasizing the Framers' apprehension about congressional interference in execution of the laws); Chadha, $462 \mathrm{U} . \mathrm{S}$. at $947-48$, 951.

315. See, e.g., Chadha, 462 U.S. at 948-50.

316. See, e.g., Synar, 478 U.S. at 724-27, 732-33; Valeo, 424 U.S. at 128-41; Chaney, 470 U.S. at 831-32. 
blinks at their far more important role as lawmakers, whose vulnerability to White House influence ought to raise equally worrisome questions of undue control from the Chief Executive.

Having sanctioned the fundamental realignment of government power that the delegation of regnlatory authority to agencies represents, the Court has proceeded to resolve issues of control over agencies as if this major restructuring of the relationships among the three named branches had never occurred. It is as if all the intellectual vigor that could be brought to separation of powers jurisprudence were channeled into the one burst of growth that sanctioned the delegation of regnlatory power, only to leave the jurisprudence spent, too exhausted to deal with the fruit of its early potency in any way other than falling back on old and now inapposite formulae.

Concededly, the alternative-approaching each case that raises questions about the relationships among the three branches and agencies by asking where the balance of power now stands and by considering how the balance will be affected by the choice to be made-is a soberingly difficult one. The assessment of whether power has shifted to the point that counterbalance is required is one that cannot be conducted under any certain, or universally agreed upon, standard. The question of when an assumption of power by one branch becomes constitutionally necessary because of the flow of power to another branch is a question that even (or, perhaps, especially) the judiciary will be hardpressed to answer in a principled fashion.

Yet one can acknowledge the difficulty of the task and concede the undesirability of giving it to judges and still insist, for one simple reason, that they must attempt to do it: whenever the Court decides one of these cases, it alters the balance of power. Refusing to recognize such cases as opportunities for adjusting the balance will not change the fact that the consequence of deciding them inevitably will be either to augment, or to stem, the flow of power towards agencies and the President. We frequently chide Congress for dereliction of duty in surrendering great chunks of power to agencies and then failing to control them. But surely the blame does not belong with the legislature alone. Having been a partner with Congress in altering the original balance of power, the Court needs to shoulder its share of responsibility for shaping the new one. 